\title{
Environmental Management Performance Report December 1999
}

Prepared for the U.S. Department of Energy Assistant Secretary for Environmental Management

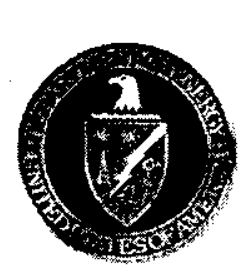

United States

Department of Energy

Richland Operations Office

P.O. Box 550

Richland, Washington 99352

Approved for Public Release; Further Dissemination Unlimited 
INFORMATION CLEARANCE FORM

A. Information Category

$\begin{array}{ll}\square \text { Abstract } & \square \text { Joumal Article } \\ \text { Summary } & \square \text { Intemel } \\ \text { Visual Aid } & \square \text { Soltware } \\ \square \text { Full Paper } & \square \text { Report } \\ \square \text { Other } & \end{array}$

B. Document Number DOE/RL-99-83, ReN I

c. Title -

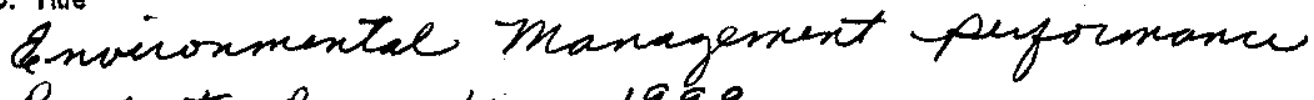
Repout Aleratien 1999

\section{E. Required Inlomation}

1. Is document potentially classified? (DNo OYes (MANDATORY $\frac{\text { Lee helow }}{\text { Manager's Signature Reguired }}$ If Yes ADC Signature Required

2. Intemal Review Regulred? if Yes, Document Signatures Below Ono OYes classified Counsel DNo Ores Program

3. References In the Information are Applied Technology (No OYes Export Conirolled Information Quio Ores
4. Does Information Contain the Following: (MANDATORY)

a. Now or Novel (Patentable) Subject Matten QNo OYes

If "Yes", Disclosure No.:

b. Information Recoived in Confidence, Such as Proprietary and/or. Inventions? (D) OYos If "Yes", Arix Approprilo Legends/Noticos.

c. Copyrights? (DNo OYes If "Yos", Attach Permission.

d. Trademarks? ONo OYes If 'Yos', Identify ln Doeument. 5. Is Information requiling submission to OSTI? . Q No $O$ Yes IrYes UC-2DVD and $B \& R-E W \quad 313007 Z$ 6. Release Level? (D) Public O Limiled.

7. Charge Code

\section{F. Complete for a Journal Article}

1. Title of Joumal

\section{G. Complete for a Presentation}

1. Titte for Conference or Meeting

2. Group Sponsoring

3. Dale of Conference

4. City/State

5. Will Information be Published in Proceedings? $O$ No $O$ Yes

6. Will Materal be Handed Out? $\bigcirc$ No $\bigcirc$ Yes

H. Author/Requestor

D. m. EDER. (Print and Sign) Responsible Manager . L.E.Maiden (Print and Sign)
I. Revlewers
Yes Print
Signature

Public $Y / N$ (II N, complete J)

General Counsel

office of Extemal Affairs

DOE-RL

$\square$

Other

Other

$\square$
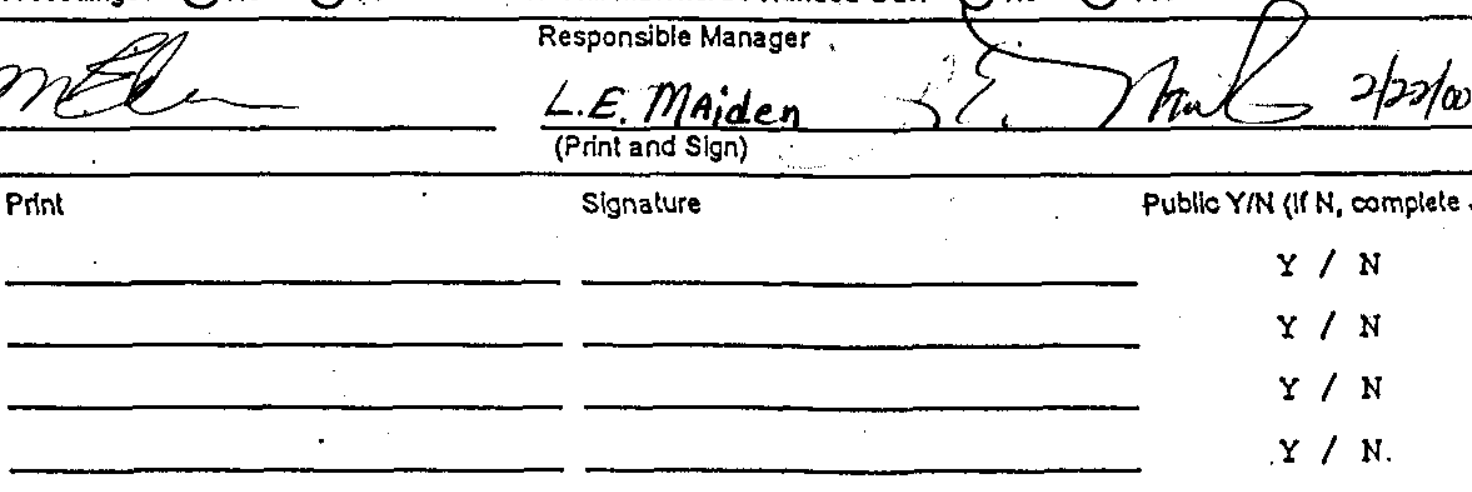

J. If Information Includes Sensitive Information and is not to be released to the Public indicate category below.
$\square$ Applied Technology
$\square$ Protected CRADA
$\square$ personavprivate
$\square$ Export Controlled
$\square$ Proprietary
$\square$ Procurement-Sensitive
$\square$ Business-sensittve
$\square$ Patentable
$\square$ Predecisional
$\square$ Other (Specify)

Q UCNI

K. If Additlonal Comments, Please Attach Separate Sheet

$Y / N$
$Y / N$
$Y / N$
$Y / N$
$Y / N$

Information Clearance Approval

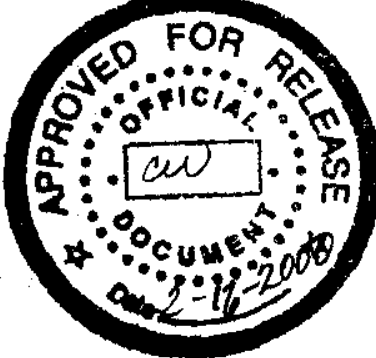


FLUOR DANIEL

Fluor Daniel Hanford, Inc.

P.O. Box 1000

Richland, WA 99352

February 28, 2000

FDH-9553093 R55

Mr. G. M. Bell, Director

Analysis and Evaluation Division

U.S. Department of Energy

Richland Operations Office

Post Office Box 550

Richland, Washington 99352

Dear Mr. Bell:

CONTRACT NO. DE-AC06-96RL13200 - ENVIRONMENTAL MANAGEMENT

PERFORMANCE REPORT - DECEMBER 1999

Attached is DOE/RL-99-83, Revision 1, "Environmental Management Performance Report December 1999," which was delivered to U.S. Department of Energy, Richland Operations Office on February 3, 2000, for final review and in bound copy on February 23, 2000. This report has been separated into four sections: Project Hanford Management Contract, Bechtel Hanford, Inc., Pacific Northwest National Laboratory and Regulatory Unit. This Gucument has been reviewed by Fluor Hanford's Site Planning and Integration management and your staff. Site Planning and Integration will continue to work with your staff regarding any additional enhancements to the report.

The monthly Environmental Management Performance Report is also available on the Internet. The website address is http://www.hanford.gov/hspr/toc.htm.

If you have any questions, no longer require the report in hard copy, or have problems accessing it electronically, please contact Mr. D. M. Eder of my staff at 376-0755.

Very truly yours,

Taduyt, mezemp

Project Controls

cas

Attachment

DOE-HQ - R. Lightner

RL - $\quad$ S. A. Sieracki w/o att.

V. Skinner w/o att. 


\section{CORRESPONDENCE DISTRIBUTION COVERSHEET}

Author

G. J. McCleary, FDH

(D. M. Eder, 376-0755)

CONTRACT NO.

Subject: $\quad$ PERFORMANCE REPORT - DECEMBER 1999

Addressee

G. M. Bell, RL

Correspondence No.

FDH-9553093 R55

\section{DISTRIBUTION}

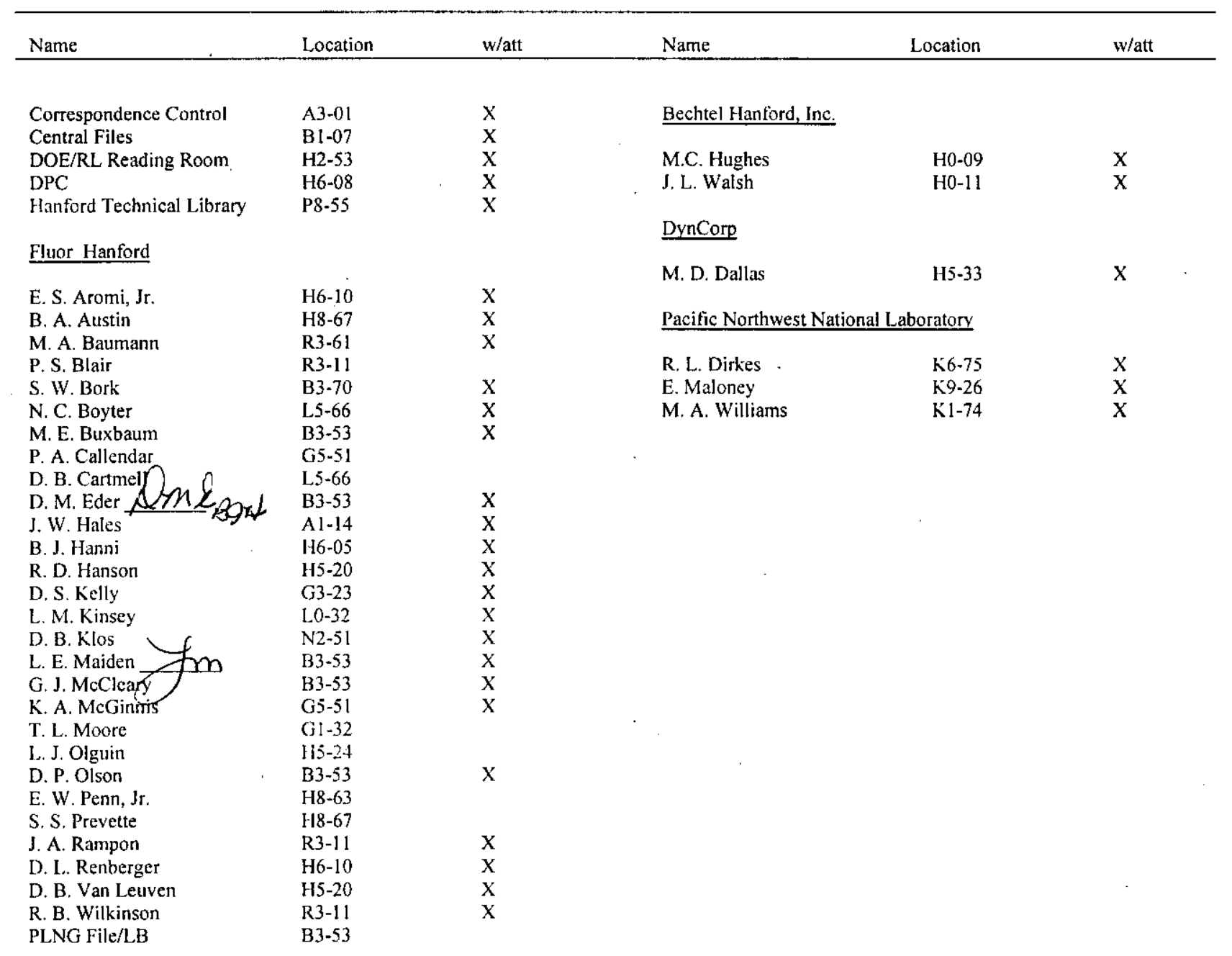




\section{Environmental Management Performance Report December 1999}

Prepared for the U.S. Department of Energy Assistant Secretary for Environmental Management

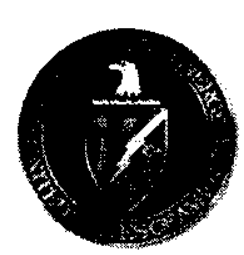

\section{United States} Department of Energy Richland Operations Office P.O. Box 550

Richland, Washington 99352 


\section{TRADEMARK DISCLAIMER}

Reference herein to any specific commercial product, process, or service by trade name, trademark, manufacturer, or otherwise, does not necessarily constitute or imply its endorsement, recommendation, or favoring by the United States Government or any agency thereof or its contractors or subcontractors.

This report has been reproduced from the best available copy. Available in paper copy and microfiche.

Available electronically at $h t t p: / / w w w . d o e . g o v / b r i d g e$. Available for a processing fee to the U.S. Department of Energy and its contractors, in paper, from:

U.S. Department of Energy

Office of Scientific and Technical Information

P.O. Box 62

Oak Ridge, TN 37831-0062

phone: 865-576-8401

fax: 865-576-5728

email: reports@adonis.osti.gov(423) 576-8401

Available for sale to the public, in paper, from:

U.S. Department of Commerce

National Technical Information Service

5285 Port Royal Road

Springfield, VA 22161

phone: 800-553-6847

fax: 703-605-6900

email: orders@ ntis.fedworld.gov

online ordering: http://wnw.htis.gov/ordering.htm 


\section{RELEASE AUTHORIZATION}

Document Number:

\section{Document} Title:
$\mathrm{DOE} / \mathrm{RL}-99-83$, Rev. 1

\begin{tabular}{|c|}
\hline $\begin{array}{c}\text { This document, reviewed in accordance with } \\
\text { DOE Order } 241.1, \text { "Scientific and Technical } \\
\text { Information Management," and DOE G 241.1-1, } \\
\text { "Guide to the Management of Scientific and } \\
\text { Technical Information," does not contain } \\
\text { classified or sensitive unclassified information } \\
\text { and is: } \\
\text { APPROVED FOR PUBLIC RELEASE }\end{array}$ \\
\hline Ahistivi Millixglemo \\
\hline $\begin{array}{c}\text { C. Wil ingham } \\
\text { Lockheed Martin Services, Inc. } \\
\text { Document Control / Information Clearance }\end{array}$ \\
\hline
\end{tabular}

Reviewed for Applied Technology, Business Sensitive, Classified, Copyrighted, Export Controlled, Patent, Personal/Private, Proprietary, Protected CRADA, Trademark, Unclassified Controlled Nuclear Information.

TRADEMARK DISCLAIMER. Reference herein to any specific commercial product, process, or service by trade name, trademark, manufacturer, or otherwise, does not necessarily constitute or imply ts endorsement, recommendation, or favoring by the United States Government or any agency thereof or its contractors or subcontractors. The views and opinions of authors expressed herein do not necessarily state or reflect those of the United States Government or any agency thereof. This report has been reproduced from the best avaitable copy.

Printed in the United States of America.

Available to the U.S. Department of Energy and its contractors from the U.S. Department of Energy Office of Scientific and Technical Information, P.O. Box 62, Oak Ridge, TN 37831; Telephone: 423/576-8401.

Available to the public from the U.S. Department of Commerce National Technical Information Service, 5285 Port Royal Road, Springfield, VA 22161; Telephone: 703/487-4650. 


\section{INTRODUCTION}

The purpose of the Environmental Management Performance Report (EMPR) is to provide the I Department of Energy Richland Operations Office's (DOE-RL's) report of Hanford's Environmental Management (EM) performance by:

- U. S. Department of Energy, Richland Operations Office,

- Project Hanford Management Contract (PHMC) through Fluor Hanford, Inc. (FHI) and its subcontractors,

- Environmental Restoration Contract through Bechtel Hanford, Inc. (BHI), and its subcontractors, and

- Pacific Northwest National Laboratories (PNNL) for EM and EM Science and Technology (S\&T) Mission.

This report is a monthly publication that summarizes EM Site performance under RL Operations Office. It is organized by the four sections listed above, with each section containing an Executive Summary and Area Performance Summaries. A listing of what is contained in the sections can be found in the Table of Contents. 


\section{PHMC Environmental Management Performance Report December 1999}



\section{Fluor Hanford}

A Fluor Global Services Company 


\section{Table of Contents}

\section{Section}

\section{A. Executive Summary}

Introduction A: 2

Notable Accomplishments .

Performance Data \& Analysis. A: 3

Cost and Schedule Performance

Milestone Performance

Safety Overview

Critical Issues.

EM Corporate Performance Measures

Major Commitments

Critical Few Performance Measures

Key Integration Activities.

Upcoming Planned Key Events

\section{B: 1. Waste Management}

Summary

Cost/Schedule Performance Graph and Tabular Data

B: $1-3$

Cost Variance Analysis

B: $1-5$

Schedule Variance Analysis.

B: $1-6$

Milestone Achievement Chart

B: $1-7$

Milestone Exception Report

B: $1-7$

Storage, Treatment and Disposal of Waste

B: $1-8$

\section{B: 2. Analytical Services (222-S, HASP, WSCF)}

Summary.

Cost/Schedule Performance Graph and Tabular Data

B: $2-3$

Cost Variance Analysis.

Schedule Variance Analysis.

B: $2-4$

Milestone Achievement Chart

B: $2-5$

Milestone Exception Report

B: $2-5$

\section{Spent Nuclear Fuel}

Summary

Cost/Schedule Performance Graph and Tabular Data

Cost Variance Analysis

C: 5

Schedule Variance Analysis.

C: 5

Milestone Achievement Chart

C: 6

Milestone Exception Report 


\section{Table of Contents}

Section

\section{D: 1. Nuclear Material Stabilization}

Summary

D: $1-1$

Cost/Schedule Performance Graph and Tabular Data

D: $1-3$

Cost Variance Analysis

D: $1-4$

Schedule Variance Analysis.

D: $1-4$

Milestone Achievement Chart

D: $1-5$

Milestone Exception Report

D: $1-6$

Material Stabilization.

D: $1-7$

Building Deactivation

D: $1-8$

\section{D: 2. River Corridor}

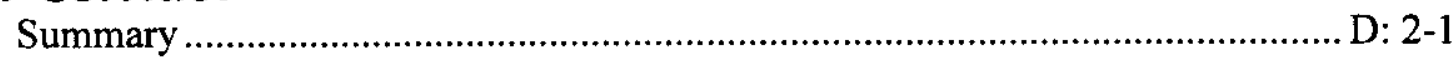

Cost/Schedule Performance Graph and Tabular Data ...................................... D: 2-4

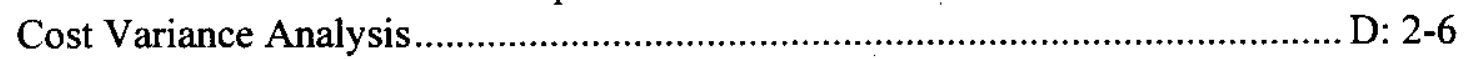

Schedule Variance Analysis................................................................ D: 2-7

Milestone Achievement Chart ............................................................ D: 2-8

Milestone Exception Report ……………………….............................. D: 2-9

Building Deactivation …………………............................................... D: 2-12

\section{E. Landlord}

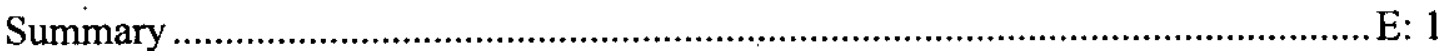

Building Deactivation and Facility Decommissioning .......................................... E: 3

F. Support

Summary F: 1

Cost/Schedule Performance Graph and Tabular Data ...........................................F: 6

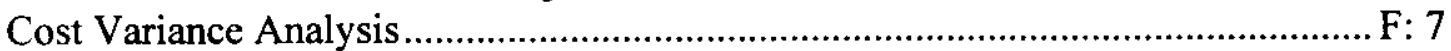

Schedule Variance Analysis.......................................................................... 7

Milestone Achievement Chart ..................................................................... 8

Milestone Exception Report …………….................................................... 8

\section{G. HAMMER}

Summary

Cost/Schedule Performance Graph and Tabular Data ............................................ 3

Cost Variance Analysis.

G: 4

Schedule Variance Analysis.

G: 4

Milestone Achievement Chart

G: 5

Milestone Exception Report 


\section{Table of Contents}

Section

\section{H. Advanced Reactors Transition}

Summary

Cost/Schedule Performance Graph and Tabular Data

H: 2

Cost Variance Analysis $\mathrm{H}: 3$

Schedule Variance Analysis.

H: 3

Milestone Exception Report H: 3

\section{EM - 50 Science \& Technology Activities}

Milestone Achievement Chart

Milestone Exception Report

J. National Programs

Cost/Schedule Performance Graph and Tabular Data $\mathrm{J}: 1$

\section{Glossary}




\section{INTRODUCTION}

$\mathrm{T}$ he purpose of this report is to provide the Department of Energy Richland Operations Office (DOE-RL) a report of the Project Hanford Management Contractors' (PHMC) Environmental Management (EM) performance by Fluor Hanford (FH) and its subcontractors. This report is a monthly publication that summarizes the PHMC EM performance. In addition, it includes some PHMC-level data not detailed elsewhere in the report.

Section A, Executive Summary, provides an executive level summary of the cost, schedule, and technical performance described in this report. It summarizes performance for the period covered, highlights areas worthy of management attention, and provides a forward look to some of the upcoming key performance activities as extracted from the PHMC baseline.

The remaining sections provide detailed performance data relative to each individual mission area (e.g., Waste Management, Spent Nuclear Fuels, etc.), in support of Section A of the report. A glossary of terms is provided at the end of this report for reference purposes. The "as of" dates for information are shown in the various sections as noted. If no date is shown the information is current as of December 31, 1999. 

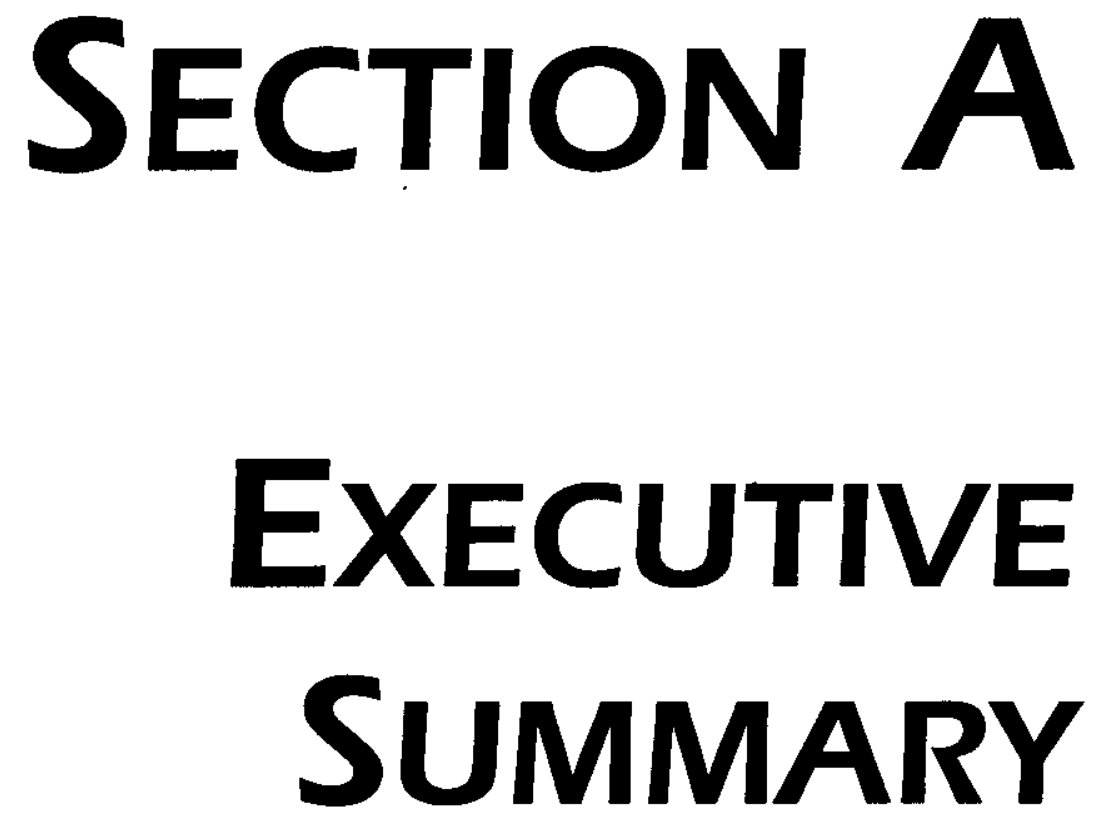

\section{AS OF DECEMBER 31, 1999}




\section{INTRODUCTION}

7 his section provides an executive level summary of the performance information covered in 1 this report and is intended to bring to Management's attention that information considered to be most noteworthy. The information is current as of the dates noted.

The section begins with a description of notable accomplishments that have occurred during the month and are considered to have made the greatest contribution toward safe, timely, and costeffective clean up. Following the accomplishment section is an overall fiscal year-to-date summary analysis addressing cost, schedule, and milestone performance. Overviews of safety ensue. The next segment of the Executive Summary, entitled Critical Issues, is designed to identify the high-level challenges to achieving cleanup progress.

The Key Integration Activities section follows next, highlighting Site activities that cross contractor boundaries and demonstrate the shared value of partnering with other Site entities to accomplish the work. Concluding the Executive Summary, a forward-looking synopsis of Upcoming Planned Key Events is provided.

\section{NOtABle ACCOMPLISHMENTS AS Of DeCEMBer 31, 1999}

- The 300 Area Fuel Supply Shutdown project is on schedule to meet the submittal of the final closure plan due on March 31, 2000.

- The Accelerated Deactivation project is making progress towards the disposition of approximately 1,865 metric tons (MT) of Hanford Unirradiated Uranium.

- Waste Management prepared for the Carlsbad Area Office Audit of Hanford's TRU Project to meet requirements of the new Part B Waste Isolation Pilot Plant (WIPP) Resource Conservation and Recovery Act Permit.

- Waste Management shipped 42 cubic meters of mixed low-level waste to ATG Inc. ATG initiated site treatment of this waste type December 22, 1999.

- DOE Richland Operations Manager Keith Klein toured the Waste Sampling and Characterization Facility (WSCF) and the 222-S Laboratory. At WSCF, Klein recognized the facility's six years without a lost day of work due to injury, since opening in October 1993.

- A total of 164 cans of plutonium oxides and sludges have been stabilized through thermal stabilization. By month's end, a total of 13 liters of plutonium nitrate solution were stabilized in the prototype vertical denitration calciner.

- The Canister Storage Building (CSB) is 94 percent complete, compared to 96 percent planned. The Cold Vacuum Drying (CVD) Facility is 92 percent complete compared to 94 percent planned.

Further details regarding the above accomplishments may be found in the individual Project Sections. 


\section{Performance Data AND Analysis as of December 31, 1999}
7 he following provides a brief synopsis of overall PHMC Environmental Management (EM) cost, schedule, and milestone performance.

\section{FY 2000 Cost and Schedule Performance}

Cost Performance - Fiscal-year-to-date (FYTD) cost performance reflects a four percent $(\$ 4.9$ million) unfavorable cost variance that is within the established $+10 /-5$ percent threshold.

Schedule Performance - There is a FYTD thirteen percent (\$17.2 million) unfavorable schedule variance.

\begin{tabular}{|c|c|c|c|c|c|c|c|}
\hline & & \multicolumn{6}{|c|}{ Data Through December 1999} \\
\hline & & \multirow{3}{*}{\begin{tabular}{|c} 
Total \\
FY PTS \\
BCWS \\
\end{tabular}} & \multicolumn{5}{|c|}{ Current Fiscal Year Performance (S x Million) } \\
\hline & & & \multicolumn{3}{|c|}{ FYTD } & \multirow{2}{*}{$\begin{array}{l}\text { Schedule } \\
\text { Variance } \\
\end{array}$} & \multirow{2}{*}{$\begin{array}{c}\text { Cost } \\
\text { Variance }\end{array}$} \\
\hline & & & BCWS & BCWP & ACWP & & \\
\hline 1.2 & $\begin{array}{l}\text { Waste Management } \\
\text { TP02,WM03-05 }\end{array}$ & 105.2 & 23.5 & 21.9 & 20.8 & $\cdot(1.6)$ & 1.1 \\
\hline 1.2 .4 & $\begin{array}{l}\text { Analytical Sves (222-S,HASP,WSCF) } \\
\text { WM06 }\end{array}$ & 25.7 & 5.9 & 5.8 & 6.4 & $(0.1)$ & $(0.6)$ \\
\hline 1.3 & Spent Nuclear Fuel & 195.1 & 43.5 & 33.8 & 44.6 & (9.7) & $(10.8)$ \\
\hline 1.4 .5 & $\begin{array}{l}\text { Nuclear Materials Stabilization } \\
\text { TP0S }\end{array}$ & 127.9 & 30.6 & 27.3 & 21.8 & (3.3) & 5.4 \\
\hline 1.4 & $\begin{array}{l}\text { River Corridor } \\
\text { TP01,TP04,TP08,TP10,TP12,TP14 }\end{array}$ & 58.2 & 12.9 & 11.4 & 11.3 & $(1.5)$ & 0.1 \\
\hline 1.5 & $\begin{array}{l}\text { Landlord } \\
\text { TP13 }\end{array}$ & 0.0 & 0.0 & 0.0 & 1.5 & 0.0 & (1.5) \\
\hline 1.8 & $\begin{array}{l}\text { Mission Support } \\
\text { OT01, OT04 }\end{array}$ & 28.1 & 10.3 & 9.8 & 9.1 & $(0.5)$ & 0.8 \\
\hline 1.9 & $\begin{array}{l}\text { HAMMER } \\
\text { HM01 }\end{array}$ & 5.5 & 1.3 & 1.3 & 1.2 & 0.0 & 0.0 \\
\hline \multirow[t]{2}{*}{1.12} & Advanced Reactors (EM) & 1.3 & 0.3 & 0.3 & 0.3 & 0.0 & 0.0 \\
\hline & PHMC EM Clean-Up Projects & 547.0 & 128.3 & 111.6 & 117.0 & (16.7) & (5.4) \\
\hline \multirow[t]{4}{*}{1.11} & $\begin{array}{l}\text { National Programs } \\
\text { OT02-03, OT06, WM07 }\end{array}$ & 5.8 & 1.1 & 1.1 & 0.7 & 0.0 & 0.3 \\
\hline & $\begin{array}{l}\text { Technology Development } \\
\text { (EM-50) }\end{array}$ & 23.4 & 4.9 & 4.3 & 4.0 & $(0.6)$ & 0.3 \\
\hline & Total Other Projects & 29.2 & 6.0 & $\mathbf{5 . 4}$ & 4.7 & $(0.6)$ & 0.7 \\
\hline & Total PHMC Projects & 576.2 & 134.1 & 117.0 & 121.9 & $(\mathbf{1 7 . 2 )})^{x}$ & (4.9) \\
\hline
\end{tabular}

Notes: Column headings (BCWS, BCWP, etc.) are defined in the glossary at the end of the report. Calculations are based on Project Baseline Summary detail. Waste Management and Nuclear Materials Stabilization have included RL-Directed costs (e.g. steam and laundry) in the PTS BCWS. Advanced Reactors (EM) have included steam.

The following Cost/Schedule and Variance to Plan charts provide an overall graphical view of fiscal year to date performance. In addition, the first chart shows the budget phasing for the entire year. The second chart portrays cost and schedule performance indicators. 


\section{FY 2000 Cost / Schedule Performance Cumulative to Date Status}
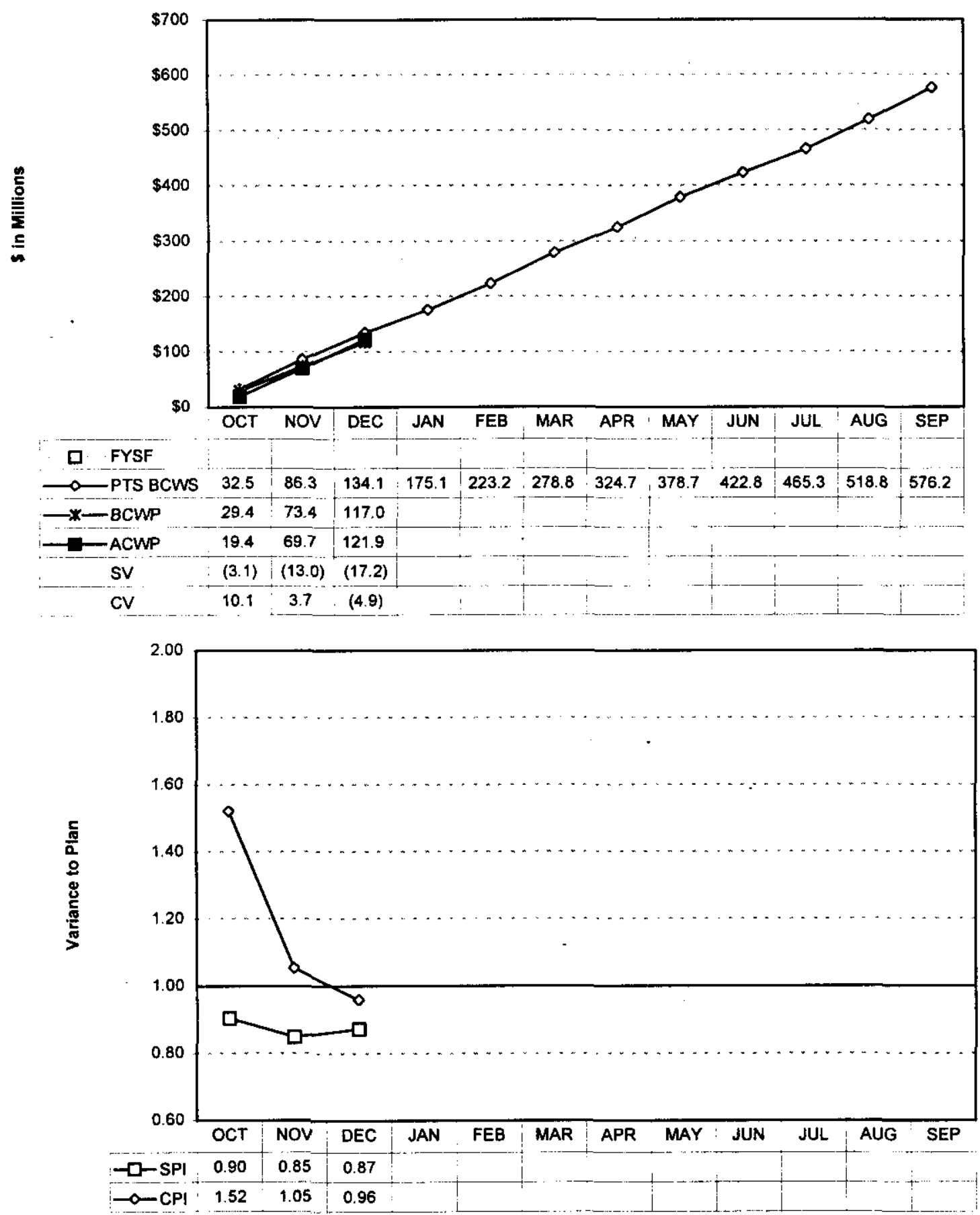

\section{Milestone Performance as Of December 31, 1999}

Milestones represent significant events in project execution. They are established to provide a higher level of visibility to critical deliverables and to provide specific status about the accomplishment of these key events. Because of the relative importance of milestones, the ability to track and assess milestone performance provides an effective tool for managing the PHMC EM cleanup mission. 


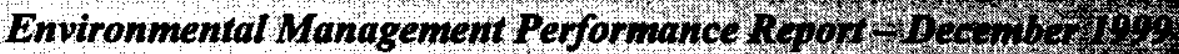

FYTD milestone performance (Enforceable Agreement [EA], U.S. Department of Energy-Headquarters [DOE-HQ], and RL) shows that 16 of 27 approved baseline milestones (59 percent) were completed on or ahead of schedule; 1 milestone (4 percent) was completed late; and 10 milestones ( 37 percent) are overdue. The 10 overdue milestones are associated with four projects: Nuclear Material Stabilization-one, River Corridor-two, Environmental Management (EM)-50-six, and Spent Nuclear Fuel—one. These overdue milestones do not share a common cause.

In addition to the FY2000 milestones described above, there are eight overdue milestones from prior fiscal years (FY1998 and FY1999). Further details regarding these milestones may be found in the Project Sections.

FY 2000 information is depicted graphically below and on the following page. For additional details related to the data in the graphs and prior year milestones, refer to the relevant project section titled "Milestone Exception Report."

FY 2000 information reflects the current approved baseline. Changes in both the number and type of milestones from month to month are the result of Baseline Change Requests (BCRs) approved during the year.

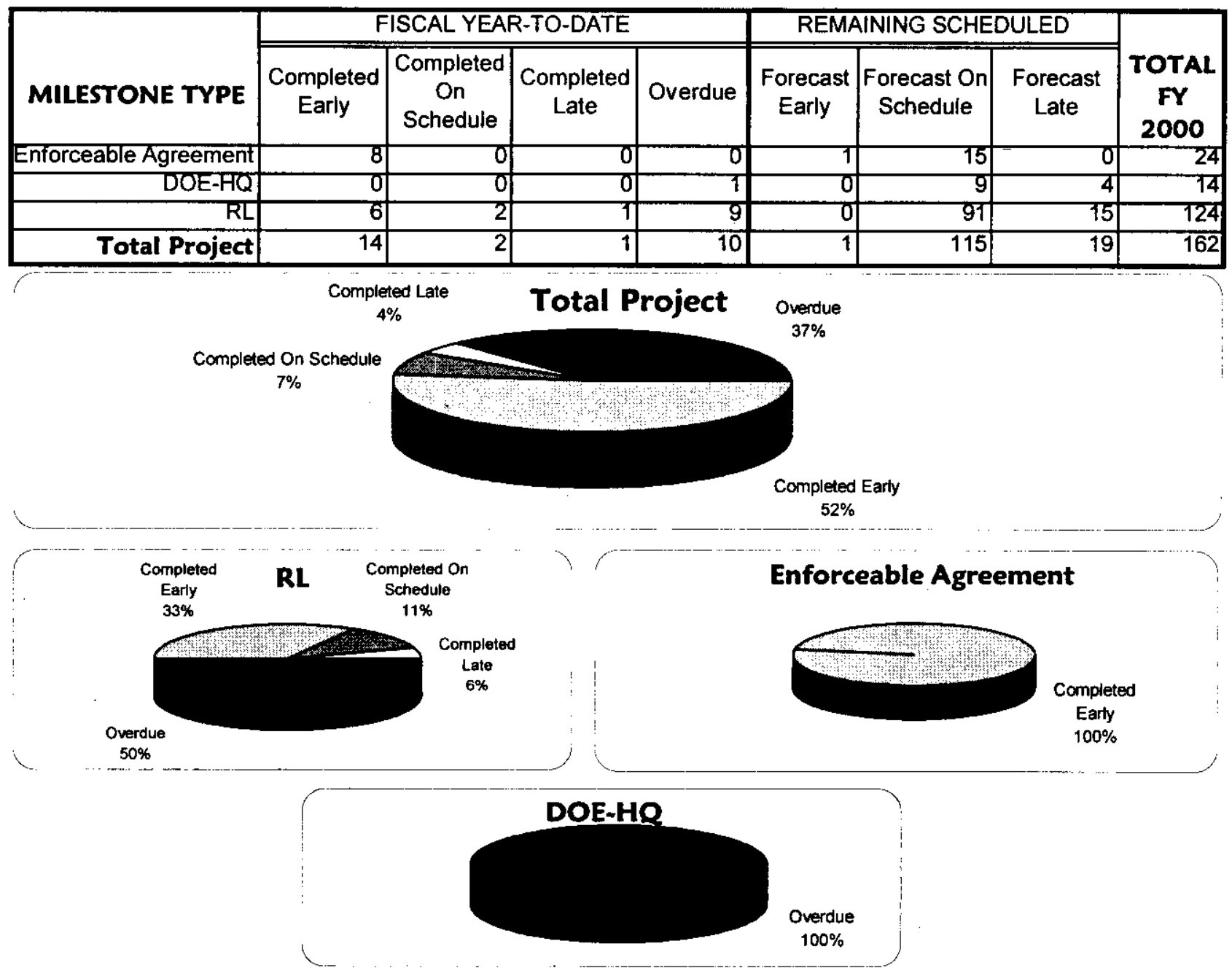




\section{MILESTONE EXCEPTIONS}

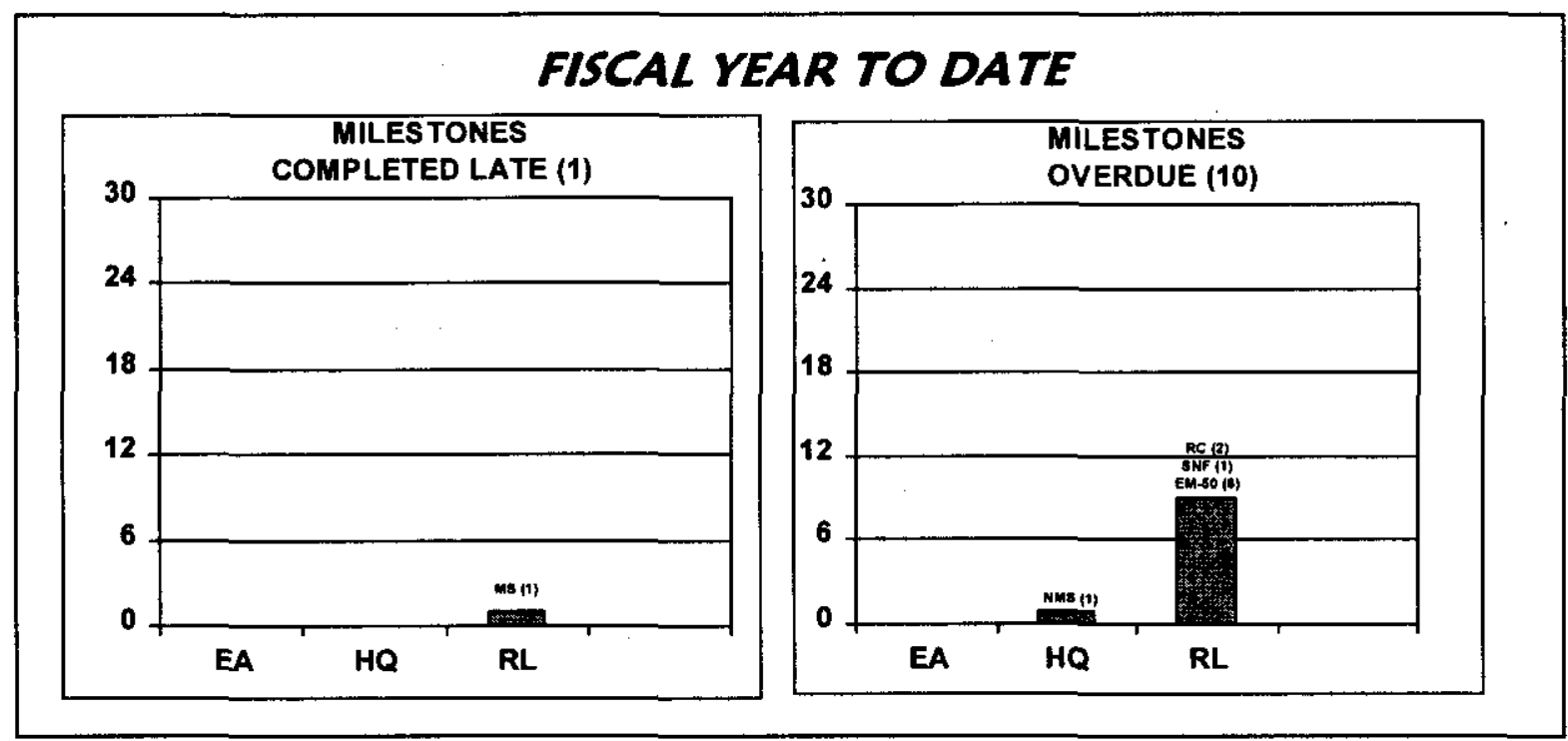

\section{REMAINING SCHEDULED}

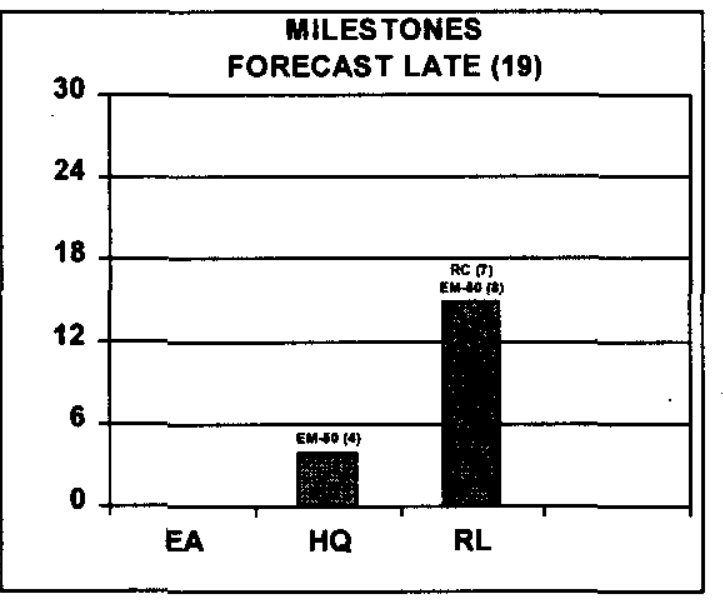

These charts provide detail by project and milestone level / type for milestones

- Completed Late

- Overdue

- Forecast Late

- Detailed information can be found in the individual project sections

\section{Safety OVerview as OF DeCeMber 31, 1999}

$\mathrm{T}$ The focus of this section is to document trends in accidents. Improvements in these rates are due to the efforts of the PHMC workforce as they implement the Integrated ES\&H Management System (ISMS), work towards achieving Voluntary Protection Program (VPP) "star" status, and accomplish work through Enhanced Work Planning (EWP). Safety and health statistical data is presented in this section.

\section{Significant Safety and Health Events}

PHMC Statistics - Rates have been stable over nearly two years. This plateau has been recognized, and Fluor Hanford kicked off its Integrated Safety Approach initiative on December 6, 
1999 in order to take safety performance to a new level. This initiative focuses upon the "people side" of accident prevention.

\section{Total OSHA Recordable Case Rate}

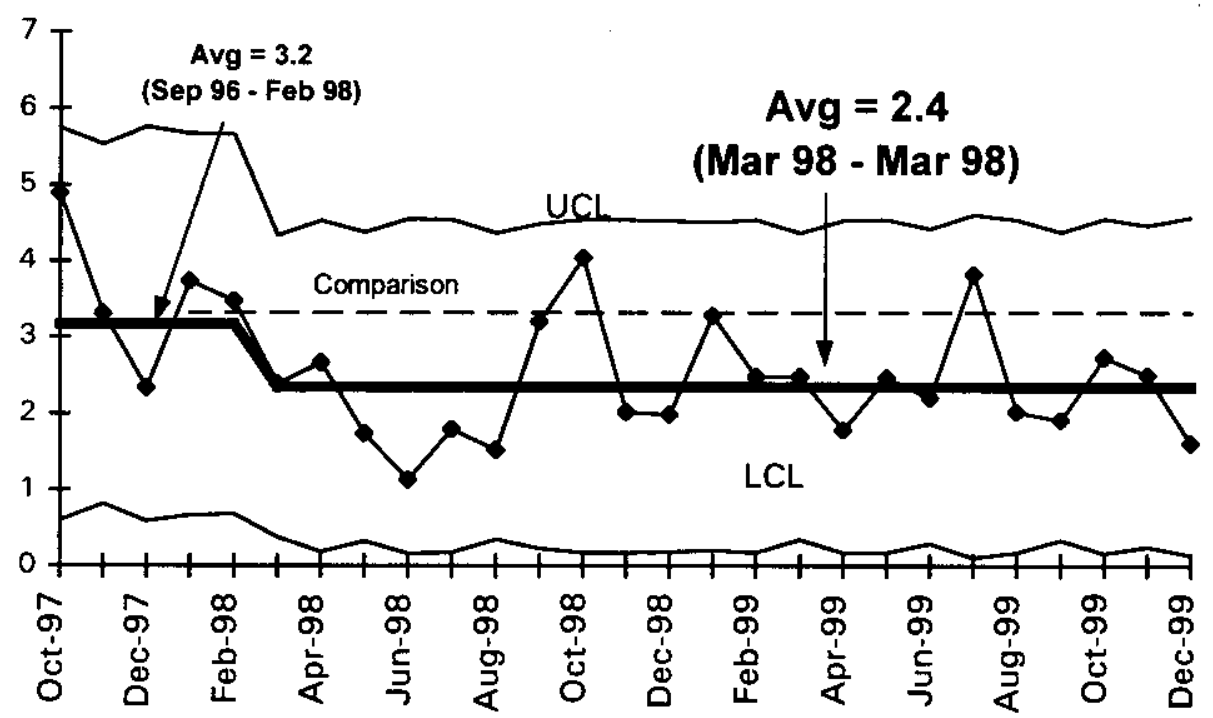

FY $1999=2.5$

FY $2000=2.3$

Contractor Comparison

Average $=3.3$

This indicator has been stable since March 1998.

The PHMC does recognize that this data has "plateaued" and is committed to taking action to gain a new reduction in injury rates.

\section{OSHA Recordable Case Rate}

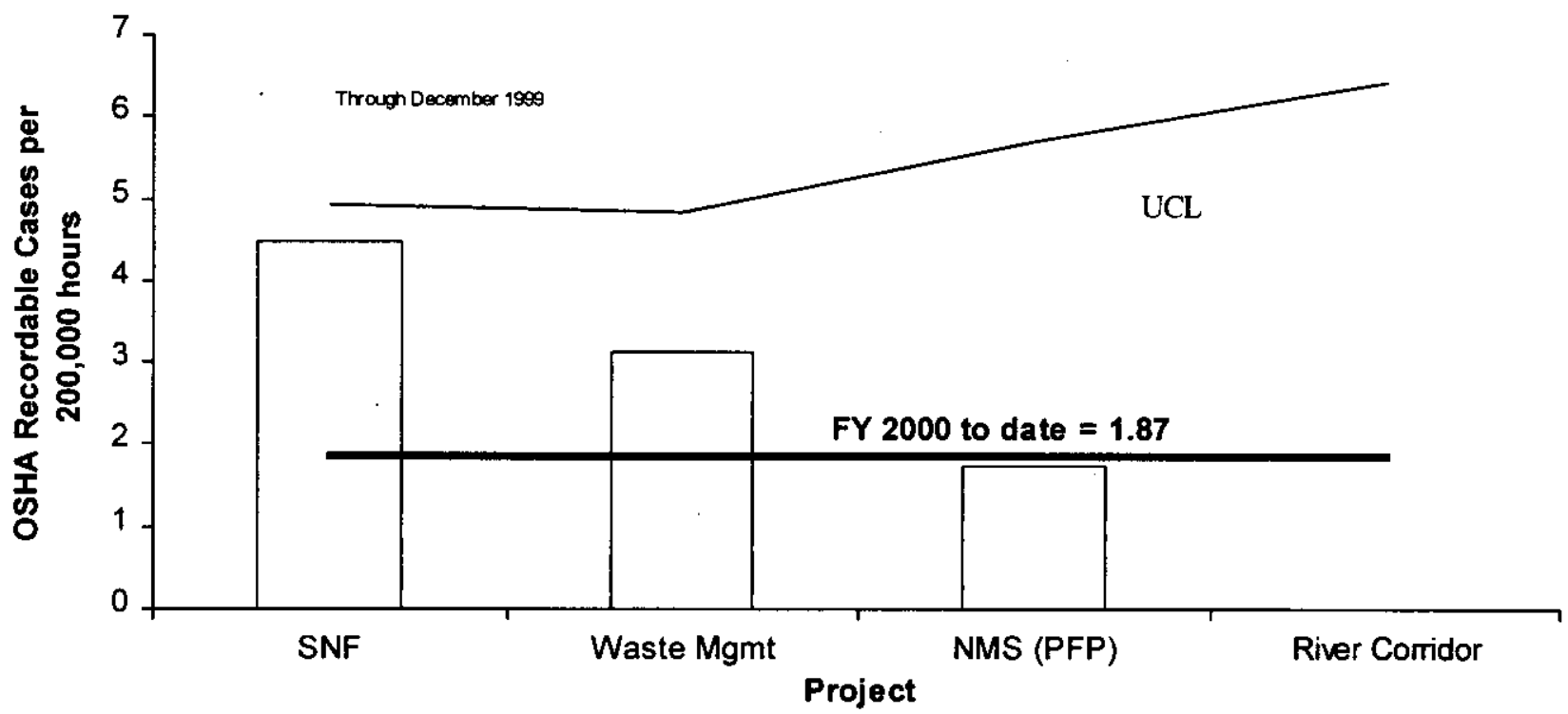

This graph reflects the project reorganization at the PHMC for FY 2000. There are four major projects, Spent Nuclear Fuels (SNF), Waste Management Project, Nuclear Material Stabilization (NMS), and River Corridor Project.

River Corridor Project has shown a significant improvement in its case rates.

SNF is showing some adverse trends in the beginning of FY 2000 as compared to FY 1999. Waste Management Project has been stable at relatively high case rate levels. 


\section{OSHA LOST/RESTRICTED WORKDAY CASE RATE}

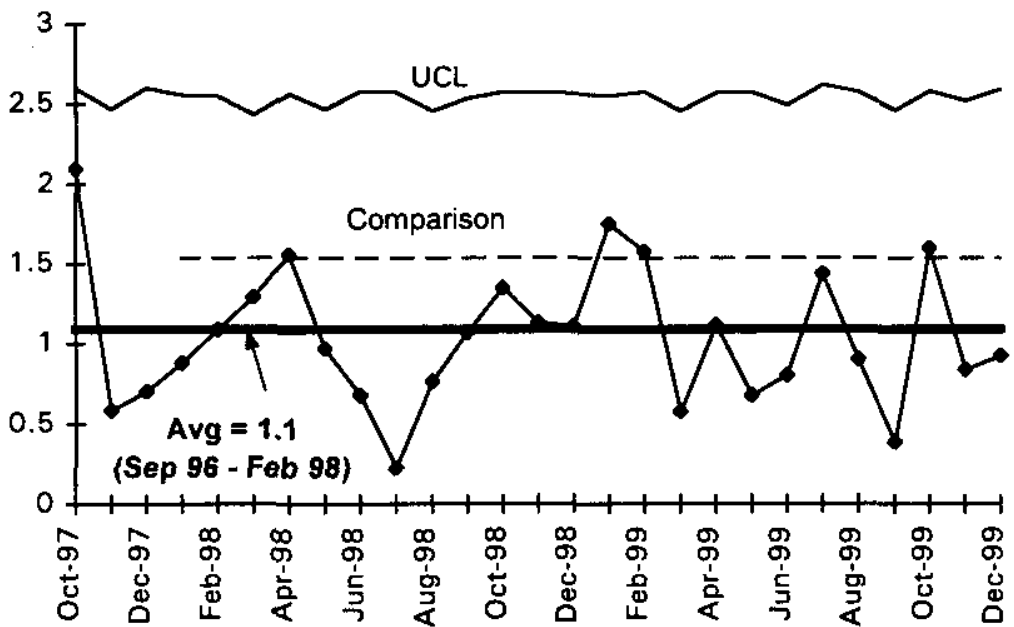

FY 1999 a 1.0

FY 2000 to date $=1.1$

Contractor Comparison

Average $=1.5$

The data have been stable

for the past two years.

\section{First Aid Case Rate}

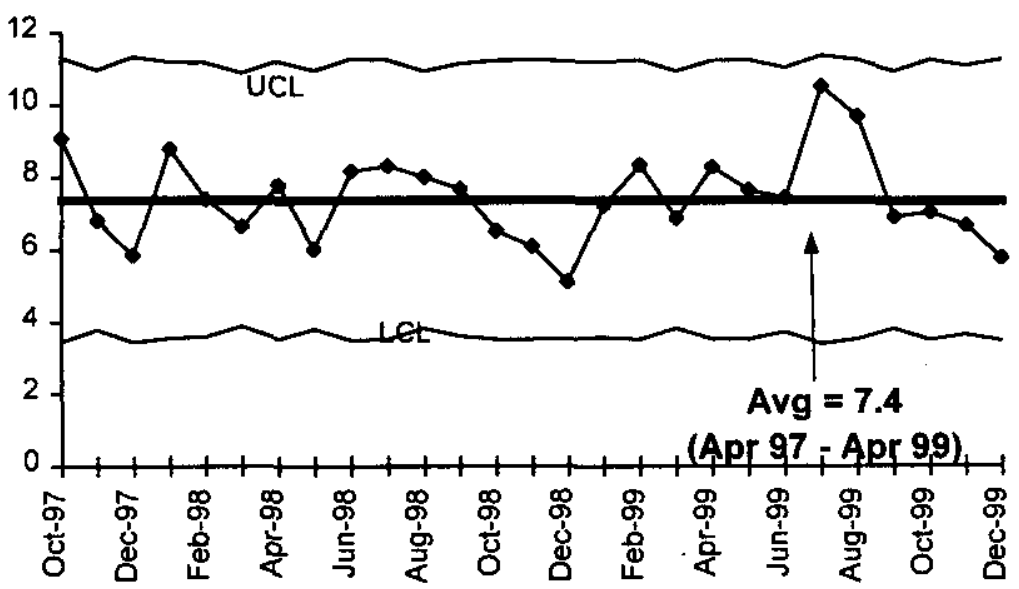

First Aid Rate undergoes seasonal cycles. Increases occur in warmer weather due to insect and animal encounters, and due to wind related minor injuries. The previously noted summer 1999 increase reduced due case reclassifications.

\section{DOE Safety Cost Index}

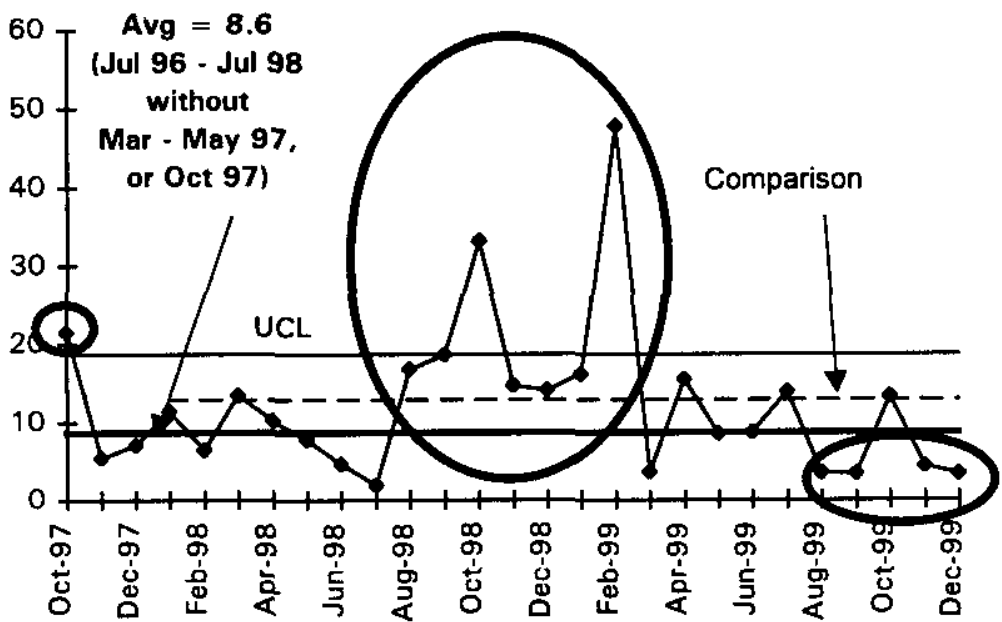

FY $1999=14.8$

FY 2000 to date $=6.9$

Contractor Comparison

Average 12.8

There has been a long term cycle over the past three years of decreases for 7 to 9 months, followed by increases. Past 4 of 5 months have been one standard deviation below average, a significant decrease. 


\section{Critical Issues as Of DeCEMBer 31, 1999}

- B CELL CLEANOUT SIX MONTHS BEHIND SCHEDULE

The 324 B Cell cleanout effort continues to experience delays as a result of systems and equipment failures. Extensive effort by the facility is focused on crane repairs. Recovery of schedule is expected through the implementation of the updated PMP recovery plan, shift work and an accelerated shipping schedule.

\section{- WIPP CERTIFICATION REQUIREMENTS}

Changing WIPP Certification requirements may cause certification and initial shipment of TRU waste to slip by at least 4 weeks. Negotiations between the DOE Waste Management Division, Waste Management Project and Carlsbad Area Office will continue.

\section{eM Corporate Performance Measures as of December 31,} 1999

\begin{tabular}{|c|c|c|c|}
\hline Performance Measures & $\begin{array}{c}\text { FY } 2000 \text { Current } \\
\text { Baseline }\end{array}$ & $\begin{array}{l}\text { FYTD } \\
\text { Planned }\end{array}$ & $\begin{array}{l}\text { FYTD } \\
\text { Actual }\end{array}$ \\
\hline \multicolumn{4}{|l|}{ Facilities Deactivated/Decommissioned } \\
\hline Facilities deactivated & 21 & 4 & \\
\hline Facilities decommissioned & 0 & 0 & \\
\hline \multicolumn{4}{|l|}{ TRansUranic (TRU) Waste } \\
\hline Stored - total inventory $\left(\mathrm{m}^{3}\right)$ & 16,333 & 16,333 & 16,347 \\
\hline Treated $\left(\mathrm{m}^{3}\right)$ & 0 & 0 & 0 \\
\hline Disposed (shipped to DOE site $\mathrm{m}^{3}$ ) & 35 & 0 & 0 \\
\hline \multicolumn{4}{|l|}{ High Level Waste } \\
\hline Treated $\left(\mathrm{m}^{3}\right)$ & 3,600 & 0 & 0 \\
\hline \multicolumn{4}{|l|}{ Mixed Low Level Waste } \\
\hline Stored - total inventory $\left(\mathrm{m}^{3}\right)$ & 8,567 & 9,099 & 9,318 \\
\hline Treated $\left(\mathrm{m}^{3}\right)$ & 1,060 & 280 & 0 \\
\hline \multicolumn{4}{|l|}{ Low Level Waste } \\
\hline Stored - total inventory $\left(\mathrm{m}^{3}\right)$ & 180 & 180 & 180 \\
\hline Disposed (on-site/commercial) $\left(\mathrm{m}^{3}\right)$ & 6,936 & 2,234 & 1,032 \\
\hline \multicolumn{4}{|l|}{ Material Stabilized } \\
\hline Plutonium Oxide (cans) & 140 & 47 & 164 \\
\hline Plutonium Solution (L) & 255 & 0 & 13 \\
\hline Uranium in other forms $(\mathrm{kg})$ & 17 & 17 & 17 \\
\hline Technology Deployments & 21 & 23 & 23 \\
\hline \multicolumn{4}{|l|}{\begin{tabular}{|l} 
Pollution Prevention \\
\end{tabular}} \\
\hline HAZ (MT) & 48 & 45 & 5 \\
\hline SAN (MT) & 1,781 & 1,781 & 182 \\
\hline LLW (m3) & 494 & 469 & 69 \\
\hline MLLW (m3) & 146 & 139 & 22 \\
\hline \multicolumn{4}{|l|}{ Cleanup/Stabilized Waste Avoided } \\
\hline FY 1999 planned baseline amount $\left(\mathrm{m}^{3}\right)$ & 1,920 & 1,920 & 1,386 \\
\hline FY 2000 planned baseline amount $\left(\mathrm{m}^{3}\right)$ & 1,926 & 1,926 & $\mathrm{~N} / \mathrm{A}$ \\
\hline
\end{tabular}

All of the above reflect the year end status. For deviations $+/-10 \%$, see the

All of the above reflect the first quarter status. For deviations $+/-10 \%$, see the following project sections: MLLW treatment - Waste Management Project; and Materials Stabilized, Plutonium Oxide and Solution - Nuclear Materials Stabilization Project. 


\section{MAJOR COMMITMENTS AS OF DECEMBER 31, 1999}

\section{Milestones}

Nudear Materials Stablization

Install 2 LANL Pyrolysis Units for Stabilization of Polycubes (TRP-00-500)

Deliver Core Sample Data Pkgs, for TANK

2412361DISP (M-015-37B)

\section{Mission Support}

Biennial Assess, of Info. \& Data Access Needs EPAFCO (2000-2046)

Submit an Annual Hanf Land Disposal Rest Rept (For FY 2000-2046)

\section{Spent Nuclear Fuels}

Complete KW CASK Facility Mods

(M-034.14A)

Provide Remedial Design report to EPA (M 034-04)

Waste Management

Issue Transuranic/Transuranic-Mixed Waste PMP (M 091-03)

Complete Construction CH TRU/TRUM

Retrieval Facility (M-091 04$)$

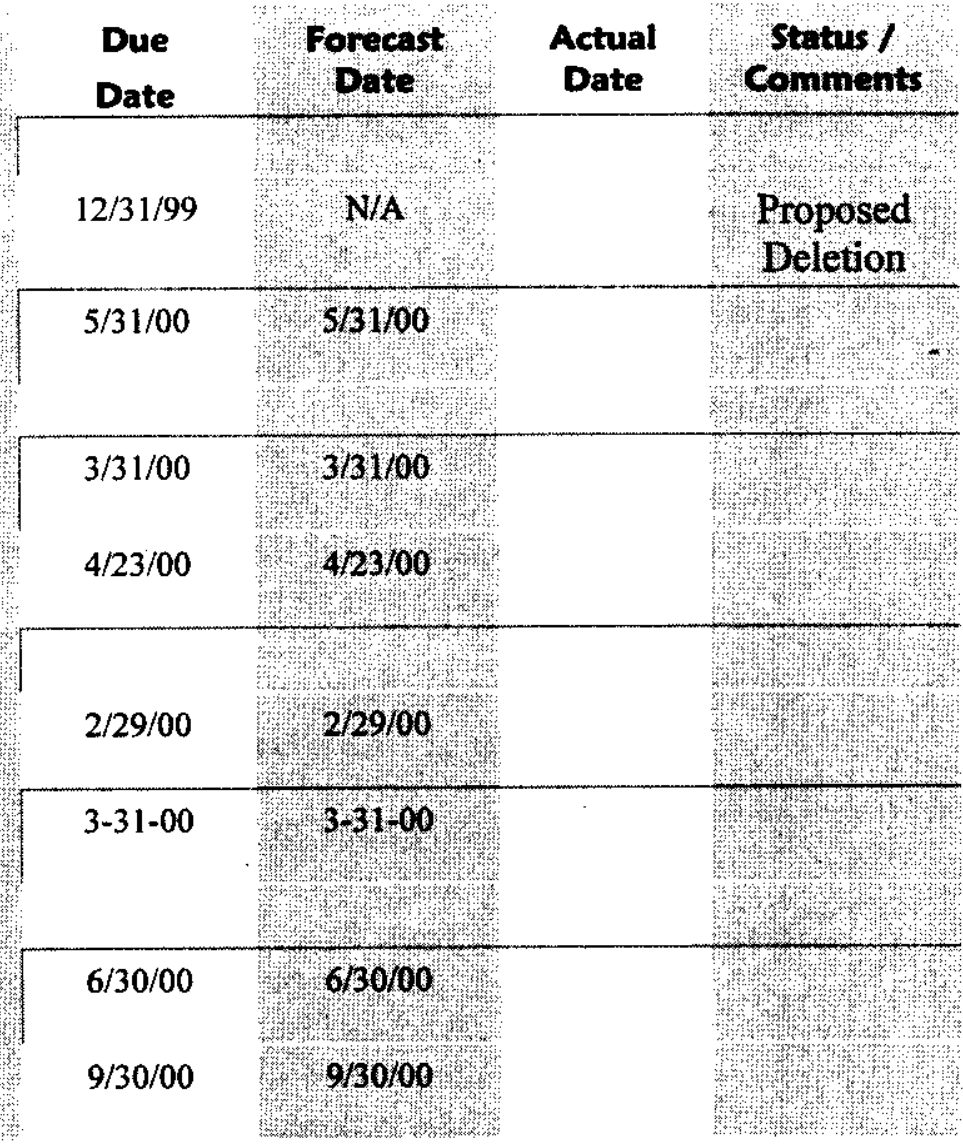

\section{Critical Few Performance Measures as of December 31, 1999}

\section{Performance Measure Spent Nuclear Fuel:}

Measure - Amount of fuel removed

Declaration of Readiness to move SNF and Phased Startup Initiative Phases I \& II

K-East Fuel Retrieval System facility modifications to allow FRS installation

Measure - Amount of SNF Stabilized

\section{$324 / 327$ Building Deactivation:}

Measure - Number of buildings dispositioned

\section{Waste Management:}

Measure - Adequacy of waste management services support

Number of analytical equivalent units (AEU's) analyzed

Through-put efficiency of effluent treatment facility (ETF) gpm

Number of 242-A evaporator campaigns completed

Measure - Retrieve and ship TRU offsite

Number of drums retrieved

Number of shipments to WIPP

Measure - MLLW Treated (m3)

Measure - MLLW Disposed (m3)

\section{Plutonium Stabilization:}

Measure - Pu metal/oxides/other types dispositioned (items)

Status as of

December 31, 1999
Yellow

Yellow

NA FY 2000

Green

Green

Green

Green

Green

Green

Green

Green

Yellows noted above are behind schedule but recoverable, action plans in place. 


\section{KeY INTEGRATION ACTIVITIES AS OF DECEMBER 31, 1999}

The following are the key technical integration activities that are currently underway and cross 1 project/contractor lines. These activities are being addressed by inter-discipline and interproject groups and demonstrate that Hanford Site contractors are working together to accomplish the EM Clean up mission.

1) 324 Building SNF removal. Interface: SNF/River Corridor Project

Status: $\quad$ An Acceptance Criteria was issued by the SNF Project to establish conditions for receipt of the SNF from the 324 Building. 324 Building BCell Cleanout Project along with the SNF project has developed an alternative plan for the fuel removal activity. Pending documentation, RL approval will be requested.

2) Activity: Complete National Facility Deactivation Initiative (NFDI) DOEcomplex Implementation Plan.

Interface: River Corridor Project / Westinghouse Savannah River (WSR) / Oak Ridge / Idaho National Engineering and Environmental Laboratory (INEEL) / Rocky Flats Environmental Technology (RFET)/ DOE-RL, SR, HQ

Status: $\quad$ NFDI team developed MOU between DOE (SR, RL \& HQ) and contractors (WSR, FH) for the deactivation planning at F Canyon, FB Line and associated facilities at SR. A resource loaded schedule for development of the Work Unit Library, field walk downs and estimating for $\sim 40$ facilities at INEEL was prepared. Also, survey reports on five pipeline facilities at the Oak Ridge, Tennessee site were completed along with the data consolidation in support of upcoming engineering study per Kaiser-Hill's request. The data will be used to compare the RFET site's needs with the Centralized Automated Modular Mobile (CAMM) solutions.

3) Activity: Canyon Disposition Initiative (CDI).

Interface: River Corridor Project / Waste Management (WM) / Bechtel Hanford, Inc. Status: $\quad$ Continued evaluation of U Plant internal structure condition from video. Briefed FH Project Acceleration team on CDI concept; concluded discussion with WM on CDI work scope ownership resulting in scope/funds/personnel to be transferred to WM.

4) Activity: Options Evaluation \& Cold Demonstration for HLV Tank 105 inspection, sampling and decontamination.

Interface: River Corridor Project / Pacific Northwest National Laboratory (PNNL) / other DOE sites

Status: The study of HLV Tank 105 , located in the 324 building is being conducted to demonstrate new technology in the deactivation of high dose radioactive tanks. This new technology has applications at other Hanford locations as well as other DOE sites. DOE-HQ is funding AEA Technologies to perform this effort, which was initiated in December. 
5) Activity: Groundwater/Vadose Zone Integration.

Interface: $\quad \mathrm{BHI} / \mathrm{PHMC} / \mathrm{PNNL}$

Status: $\quad$ Multi-contractor team implementing an integrated site strategy for assessment of groundwater pathways.

6) Activity: Collaboration on procurement of Experimental Breeder Reactor (EBR)-II casks and revision to existing EBR-II Safety Analysis Report for Packaging (SARP) to reduce procurement costs and the number of EBR-II Cask SARP revisions

Interface: PNNL/PHMC-Nuclear Material Stabilization

Status: It was determined that current changes to the SARP, which are being performed as a result of Facility Stabilization's plans to use the EBR II Cask for disposal of 324 Building spent fuel, may already bound the types and quantities of spent fuel for use by PNNL. PNNL obtained a final draft of the revised EBR II cask SARP and is still evaluating the revisions bound (i.e., how the set of parameters compare to) the PNNL material. This verification is expected to be completed in early CY-00. Preliminary indications are that the EBR-II will be acceptable. In addition the PHMC is reevaluating its need to use the EBR-II cask and may not proceed with procurement. PNNL has requested the PHMC to advise PNNL when this decision is made and if existing EBR-II casks can be transferred to PNNL for use.

\section{Upcoming Planned Key Events as Of December 31, 1999}

$\mathrm{T}$ he following Key events are extracted from the authorized baseline and are currently expected to be accomplished during the next three months. Most are EA, HQ or DNFSB Milestones.

\section{Waste Management:}

- Preparations for initial waste shipment to WIPP

- WIPP certification audit (Waste Isolation Pilot Plant in Carlsbad New Mexico) at Hanford scheduled January 2000. (NOTE: This item was completed in January). Expect approval of the Hanford TRU Certification Program March/April 2000.

- First shipment scheduled April 2000

Spent Nuclear Fuels:

- Initiate cold testing of KW Basin Fuel Retrieval System, January 2000

\section{River Corridor Project:}

- Complete 324 Building Project Management Plan, Rev 3, January 2000

- Move B Cell grout containers to A Cell for characterization/disposition, January 2000

- Remove 2A Rack from B Cell wall; initiate size reduction, February 2000

- $\quad$ Complete B Plant MOA commitments, February 2000

- Initiate 3-82B grout container shipments to CWC, February 2000

- Complete ISMS Readiness Review, February 2000

- $\quad$ Complete 224-T Process Cell Entry for characterization, February 2000

- Perform additional 60 of 300 planned transfers from 327 Facility Dry Storage

Carousel, February 2000 


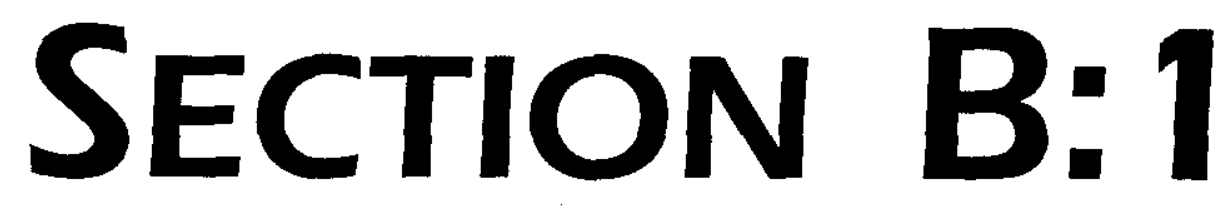

\title{
WASTE \\ MANAGEMENT \\ As OF DECEMBER 31, 1999
}

PROJECT MANAGERS

\author{
H. E. Bilson, RL \\ Phone: (509) 376-6628 \\ E. S. Aromi Jr., WMH \\ Phone: (509) 372-1033
}

DOE/RL-99-83, Rev. 1 


\section{SUMMARY}

Waste Management consists of the Solid Waste Storage and Disposal, Project Baseline Summary (PBS) WM03, Work Breakdown Structure (WBS) 1.2.1; Solid Waste Treatment, PBS WM04, WBS 1.2.2; Liquid Effluents - 200 Area, PBS WM05, WBS 1.2.3.1; and the Waste Encapsulation and Storage Facility, PBS TP02, WBS 1.4.2.

Prepared for Carlsbad Area Office Audit of Hanford's TRU Project to meet requirements of the new Part B WIPP Resource Conservation and Recovery Act Permit

- Changed approximately 60 procedures

- Retrained approximately 300 people

- Modified major documents including Quality Assurance Project Plan (QAPjP) and Certification Plan.

Shipped 42 cubic meters of mixed low-level waste (MLLW) to ATG Inc. and initiated treatment on December 22, 1999. This supports the base commitment of 1,060 cubic meters in FY 2000.

Milestone performance (EA, DOE-HQ and RL) shows no milestones are due this reporting period.

\section{ACCOMPLISHMENTS}

- Disposed 36,400 $\mathrm{ft}^{3}$ (FYTD) of Low Level Waste (LLW) in the burial grounds, as planned.

- Processed 1.9 million gallons (FYTD) of wastewater through the 200 Effluent Treatment Facility supporting River Protection Project (RPP), ERC 200-UP-1 Groundwater, N-Basin Water, and ERDF Leachate, as planned.

- Completed nondestructive examination (NDE) on 118 drums, radiography on 2 boxes, nondestructive assays of 27 drums, processing of 3 drums through the repackaging/compaction glovebox, and visual examinations of 24 transuranic drums at the Waste Receiving and Processing (WRAP) facility, as planned.

- Shipped over 1,500 cubic feet (FYTD) of mixed low-level waste to ATG for non-thermal treatment. ATG began MLLW treatment on December 22, 1999.

- Surpassed Secretary of Energy CY 1999 Pollution Prevention Goals:

\begin{tabular}{llcc} 
& Percent reduced & & Reduction Goal \\
\cline { 2 - 3 } Low-level waste & 86 & & 50 \\
Mixed low-level waste & 76 & 50 \\
Hazardous Waste & 79 & 50 \\
Toxic Chemical Release & 100 & 50 \\
Sanitary Waste & 89 & 33
\end{tabular}




\section{Cost Performance (\$M):}

\begin{tabular}{|l|c|c|c|}
\hline & BCWP & ACWP & VARIANCE \\
\hline Waste Management & $\$ 21.9$ & $\$ 20.8$ & $+\$ 1.1$ \\
\hline
\end{tabular}

The $\$ 1.1$ million (five percent) favorable cost variance is within established threshold. Further information at the PBS level can be found in the following Cost Variance Analysis details.

\section{Schedule Performance ( $\$ M)$ :}

\begin{tabular}{|l|c|c|c|}
\hline & BCWP & BCWS & VARIANCE \\
\hline Waste Management & $\$ 21.9$ & $\$ 23.5$ & $-\$ 1.6$ \\
\hline
\end{tabular}

The $\$ 1.6$ million (6.4 percent) unfavorable schedule variance is within the established threshold. Further information at the PBS level can be found in the following Cost Variance Analysis details.

\section{ISSUES}

Changing WIPP Certification requirements caused certification and initial shipment to slip until April 2000.

Strategy/Status: Continue negotiation between DOE -RL Waste Management Division, Waste Management Project and Carlsbad Area Office. An audit is scheduled at Hanford for the week of January 24, 2000. (Note: Completed in January). The first shipment is scheduled for no earlier than April 2000 following the expected approval of the Hanford TRU Certification Program.

The Waste Management Programmatic Environmental Impact Statement (PEIS) is expected to be issued in the near future. The Records of Decision (ROD) for LLW and MLLW will affect Hanford's disposal role for the Complex. The ROD outcomes may have a significant impact on disposal volumes and rates at Hanford.

Strategy/Status: Identification of DOE's notice of preference for the Waste Management Program LLW and MLLW disposal sites was published in the Federal Register on December 10, 1999. DOE will issue a ROD for LLW and MLLW treatment and disposal no sooner than 30 days after publication of the Notice.

Some current waste streams do not meet the Double Shell Tank (DST) system acceptance criteria. Waste Management is pursuing alternative disposition pathways for the 221-T tank system waste stream due to the presence of TSCA regulated PCBs.

Strategy/Status: WMH is working with FDH and DOE-RL to ensure a strong consolidated approach to compliant and effective PCB waste management. WMH has established a team to identify and propose paths for waste storage, treatment, and disposal alternatives to the DST system. Interim measures to enable continued operations are underway. 


\section{Waste Management \\ WBS 1.2}

\section{FY 2000 COST/SCHEDULE PERFORMANCE - ALL FUND TYPES}

\section{Cumulative to Date Status}
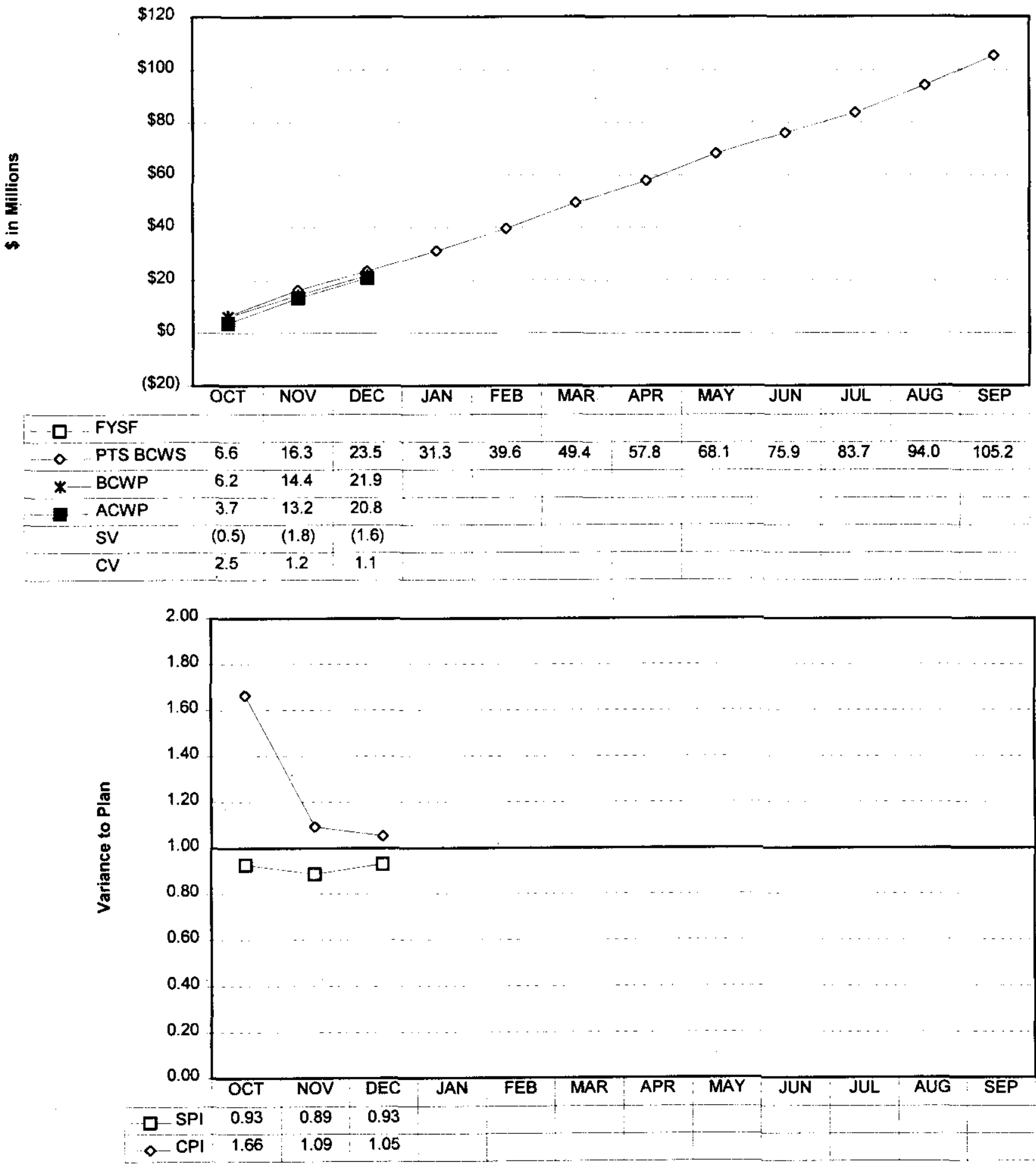


\section{WASTE ManaGement WBS 1.2 / 1.4 .2}

\begin{tabular}{|c|c|c|c|c|c|c|c|c|c|}
\hline & & & & & FYTD & & & AUTH & PTS \\
\hline & & & BCWS & BCWP & ACWP & SV & CV & BSLN & BCWS \\
\hline 1.4 .2 & WESF & Expense & 3.1 & 2.6 & 2.6 & $(0.5)$ & $(0.0)$ & 14.0 & 14.0 \\
\hline TP02 & & CENRTC & 0.0 & 0.0 & 0.0 & 0.0 & 0.0 & 0.0 & 0.0 \\
\hline & & GPP/LI & 0.0 & 0.0 & $\underline{0.0}$ & 0.0 & 0.0 & 0.0 & 0.0 \\
\hline & Subtotal 1.4 .2 & & 3.1 & 2.6 & 2.6 & $(0.5)$ & $(0.0)$ & 14.0 & 14.0 \\
\hline & & & & & & & & & \\
\hline 1.2.1. & Solid Waste & Expense & 8.3 & 8.1 & 7.5 & $(0.2)$ & 0.6 & 35.3 & 35.5 \\
\hline WM03 & Stor \& Disposal & CENRTC & 0.0 & 0.0 & 0.0 & 0.0 & $(0.0)$ & 0.0 & 0.0 \\
\hline & & GPP/LI & 0.0 & 0.0 & $(0.0)$ & 0.0 & 0.0 & 0.0 & 0.0 \\
\hline & Subtotal 1.2.1 & & 8.3 & 8.1 & 7.5 & $(0.2)$ & 0.6 & 35.3 & 35.5 \\
\hline & 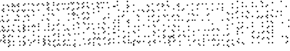 & 13 & & & & & & & \\
\hline 1.2 .2 . & Solid Waste & Expense & 5.9 & 5.1 & 5.5 & $(0.8)$ & $(0.4)$ & 26.7 & 26.7 \\
\hline WM04 & Treatment & CENRTC & 0.0 & 0.0 & $(0.0)$ & 0.0 & 0.0 & 0.0 & 0.0 \\
\hline & & GPP/LI & 0.0 & 0.0 & 0.0 & 0.0 & 0.0 & 0.0 & 0.0 \\
\hline & Subtotal 1.2.2 & & 5.9 & 5.1 & 5.5 & $(0.8)$ & $(0.4)$ & 26.7 & 26.7 \\
\hline & & & & & & & & & \\
\hline 1.2.3. & Liquid Effluents & Expense & 6.2 & 6.1 & 5.2 & (0.1) & 0.9 & 28.9 & 28.9 \\
\hline WM05 & & CENRTC & 0.0 & 0.0 & 0.0 & 0.0 & 0.0 & 0.0 & 0.0 \\
\hline & & GPP/LI & 0.0 & 0.0 & 0.0 & 0.0 & 0.0 & 0.0 & 0.0 \\
\hline & Subtotal 1.2 .3 & & 6.2 & 6.1 & 5.2 & $(0.1)$ & 0.9 & 28.9 & 28.9 \\
\hline Total h & aste Management & Expense & 23.5 & 21.9 & 20.8 & (1.6) & 1.1 & 104.9 & 105.2 \\
\hline & 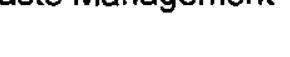 & CENRTC & 0.0 & 0.0 & $(0.0)$ & 0.0 & 0.0 & 0.0 & 0.0 \\
\hline & & GPP/LI & 0.0 & 0.0 & $(0.0)$ & 0.0 & 0.0 & 0.0 & 0.0 \\
\hline & Total & & 23.5 & 21.9 & 20.8 & $(\overline{1.6)}$ & 1.1 & 104.9 & 105.2 \\
\hline
\end{tabular}

PBS WM06, WBS 1.2.4 is included in Analytical Services, Section B: 2. The 300 Area LEF, PBS WM05, is include in the above table. 


\section{COST VARIANCE ANALYSIS: $(+\$ 1.1 \mathrm{M})$}

\section{$\underline{\text { WBS/PBS }}$}

\subsection{1/WM03}

Description/Car threshold.

Impact: No impact.

Corrective Action: No corrective action required.

\subsection{2/WM04 Solid Waste Treatment}

Description/Cause: The unfavorable cost variance of $\$ 0.4 \mathrm{M}(-7.2$ percent) is due to the initiation of FY 1999 carryover workscope (TRU PMP and TRU Retrieval).

Impact: No impact.

Corrective Action: The carryover change request will be approved in January, 2000.

\subsubsection{1/WM05 Liquid Effluents-200 Area}

Description/Cause: The favorable cost variance of $\$ .7 \mathrm{M}(14.1$ percent $)$ is due to staff vacancies and reduced sample analysis.

Impact: No impact.

Corrective Action: No corrective action required

\subsection{2/TP02 WESF}

Description/Cause: The favorable cost variance of less than $\$ 0.1 \mathrm{M}$ is within the established threshold.

Impact: No impact.

Corrective Action: No corrective action required. 


\section{SCHEDUle VARIANCe ANALYSIS: (-\$1.6)}

$\underline{\text { WBS/PBS }}$

1.2.1/ WM03

Description /Cause: The unfavorable schedule variance of $-\$ .2 \mathrm{M}(-2 \%$ percent $)$ is within the established threshold.

Impact: No Impact.

Corrective Action: No corrective action required.

\subsection{2/WM04}

Solid Waste Treatment

Description /Cause: The unfavorable schedule variance of $\$ .8 \mathrm{M}(-13.7$ percent $)$ is due to a delay in TRU production caused by WIPP permitting changes. RMW treatment is behind schedule due to ATG not completing construction on their facility.

Impact: None.

Corrective Action: ATG processing began on December 22, 1999. The schedule will be recovered. TRU production is focused only on items necessary to support the WIPP certification audit scheduled for January 24, 2000.

\subsubsection{1/WM05 Liquid Effluents-200 Area}

Description /Cause: The unfavorable schedule variance of $-\$ .1 \mathrm{M}(2.4$ percent $)$ is within the established threshold.

Impact: None.

Corrective Action: None.

1.4.2/TP02

WESF

Description /Cause: The unfavorable schedule variance of $-\$ 0.5 \mathrm{M}$ (15.9 percent) is due to the deferral of the WESF Safety Analysis Report (SAR).

Impact: None.

Corrective Action: A baseline change request is in process to defer the SAR to FY 2002. 


\section{WASTE MANAGEMENT - WBS 1.2 MILESTONE ACHIEVEMENT}

\begin{tabular}{|c|c|c|c|c|c|c|c|c|}
\hline \multirow[b]{2}{*}{ MILESTONE TYPE } & \multicolumn{4}{|c|}{ FISCAL YEAR-TO-DATE } & \multicolumn{4}{|c|}{ REMAINING SCHEDULED } \\
\hline & $\begin{array}{l}\text { Completed } \\
\text { Early }\end{array}$ & $\begin{array}{c}\text { Completed } \\
\text { On Schedule }\end{array}$ & $\begin{array}{c}\text { Completed } \\
\text { Late }\end{array}$ & Overdue & $\begin{array}{l}\text { Forecast } \\
\text { Early }\end{array}$ & $\begin{array}{c}\text { Forecast On } \\
\text { Schedule }\end{array}$ & $\begin{array}{c}\text { Forecast } \\
\text { Late }\end{array}$ & $\begin{array}{l}\text { TOTAL } \\
\text { FY } 2000\end{array}$ \\
\hline Enforceable Agreement & 0 & 0 & 0 & 0 & $\overline{0}$ & 3 & 0 & 3 \\
\hline DOE-HQ & 0 & 0 & 0 & $\overline{0}$ & 0 & 0 & $\overline{0}$ & 0 \\
\hline $\mathrm{RL}$ & 0 & 0 & 0 & 0 & $\overline{0}$ & 9 & 0 & 9 \\
\hline Total Project & 0 & 0 & 0 & 0 & 0 & 12 & $\overline{0}$ & $\overline{12}$ \\
\hline
\end{tabular}

\section{MILESTONE EXCEPTION REPORT}

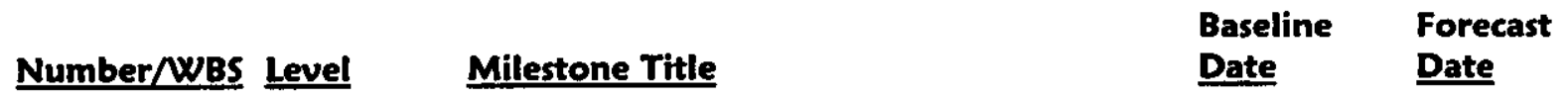

\section{OVERDUE - 0}

FORECAST LATE - 0

\section{FY 1999 OVERDUE - 1}
TRP-98-709 RL
Complete Hot Cell Deactivation
$03 / 31 / 99 \quad 06 / 30 / 00$

\subsection{2}

WESF Facility (A-E)

Cause: This milestone was not completed due to resources diverted to other higher priority areas (i.e. 200 Area contamination event, Low Level Liquid Waste project, FEB preparation).

Impact: No overall impact is expected.

Corrective Action: Awaiting determination of funding source. Cost Air Monitor 


\section{Environmental Management Performance Report - Pecensts}

Section B: 1 - Waste Management

\section{High LeVel Waste: Treatment}

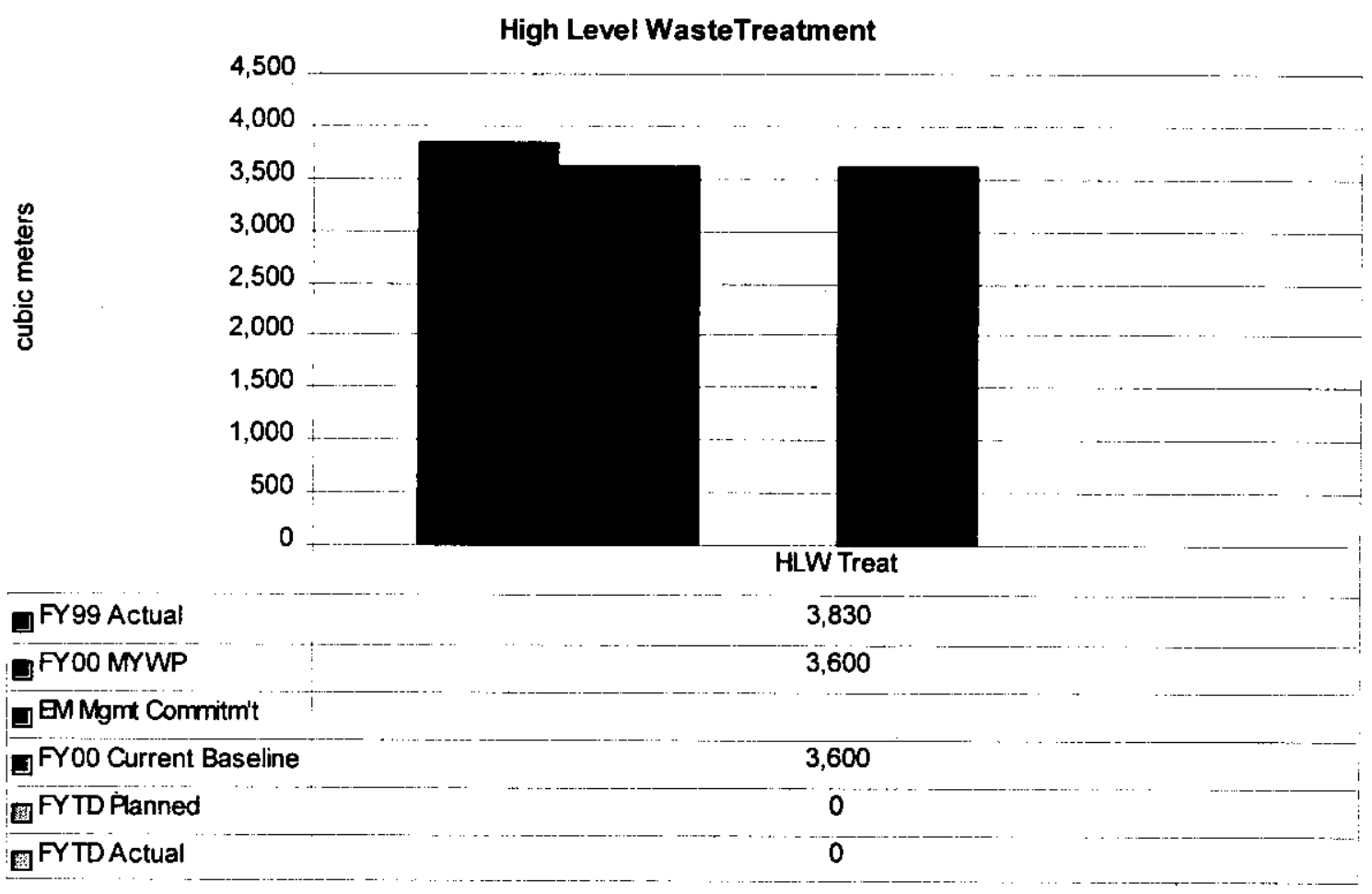

Treatment: (Waste Management Mission): Treatment via the 242-A evaporator is planned for the 4th quarter. 


\section{TransUranic (TRU) Waste: Storage, Treatment and Disposal}

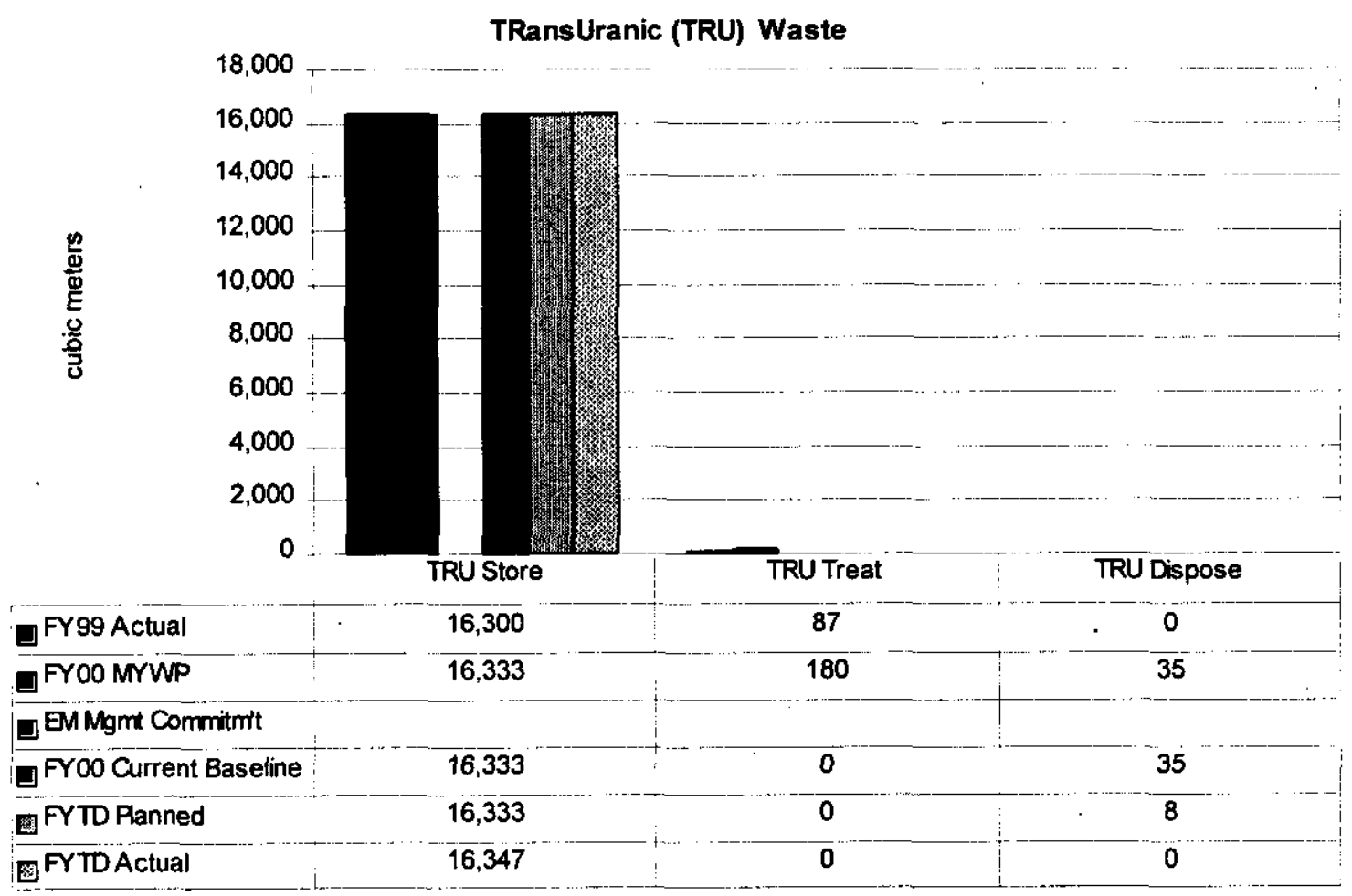

Storage: Storage continues to be provided for existing and newly generated TRU waste. The current volume of TRU in storage is within $10 \%$ of the planned amount.

Treatment: Based on DOE/RL interpretation, TRU processing at WRAP does not meet the revised TRU treatment definition. Therefore, TRU treatment volumes previously identified in the FY00 MYWP have been set to zero.

Disposal: None scheduled this period. 


\section{Mixed Low level Waste: Storage, Treatment and Disposal}

\section{Mixed Low Level Waste}

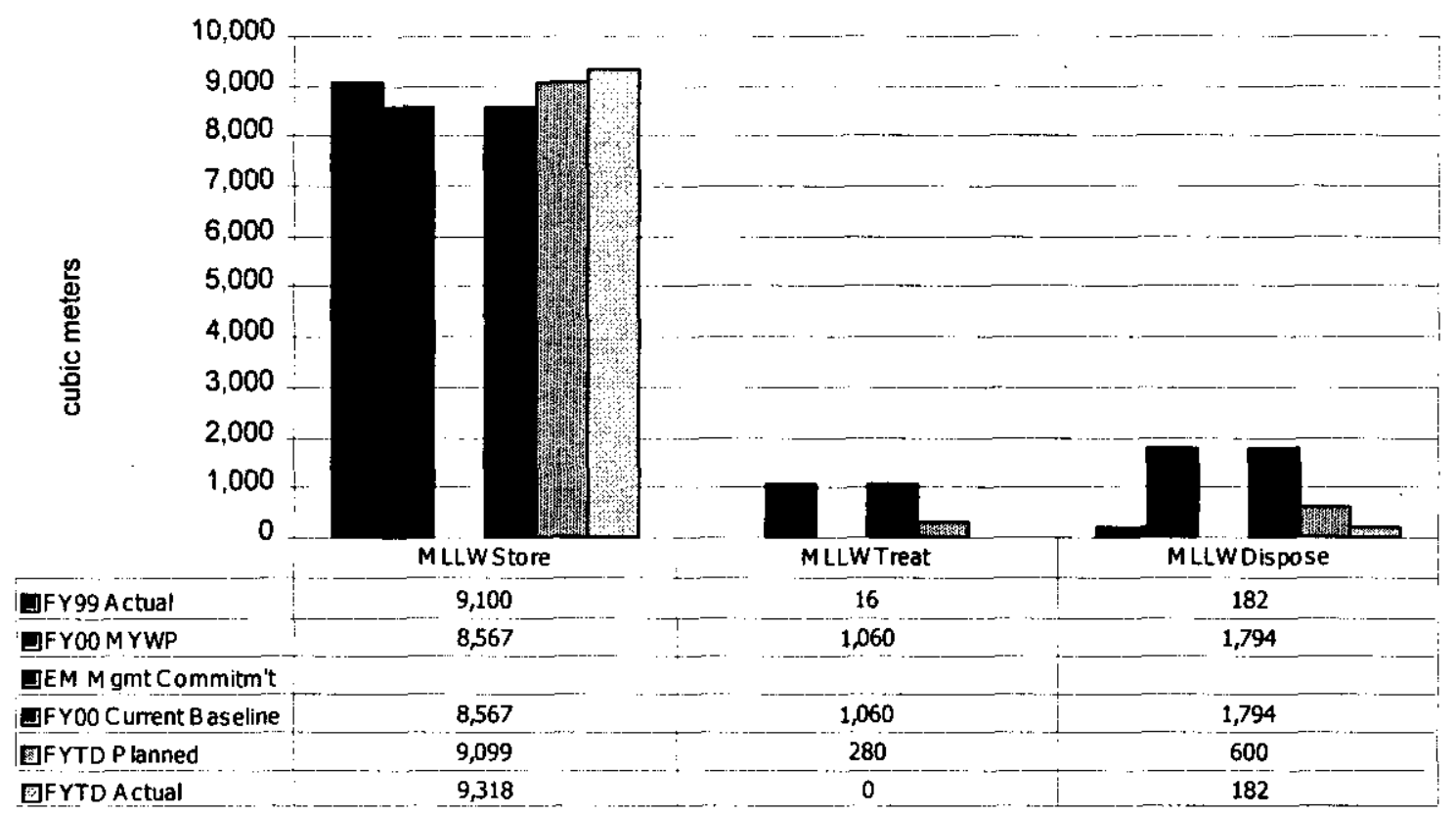

Storage: Storage continues to be provided for existing and newly generated MLLW waste. The current volume of MLLW in storage is within $10 \%$ of the planned amount.

Treatment: MLLW is in the process of being treated at Allied Technology Group (ATG). Because final waste treatment certification is not complete, the quantity of MLLW treated will not be reported until next quarter.

Disposal: MLLW being treated at ATG will require certification before disposal in the Site's Mixed Waste Disposal Trench. Both disposal and treatment FY00 totals are expected to be met. 


\section{Low level Waste: Storage, Treatment and Dispósal}

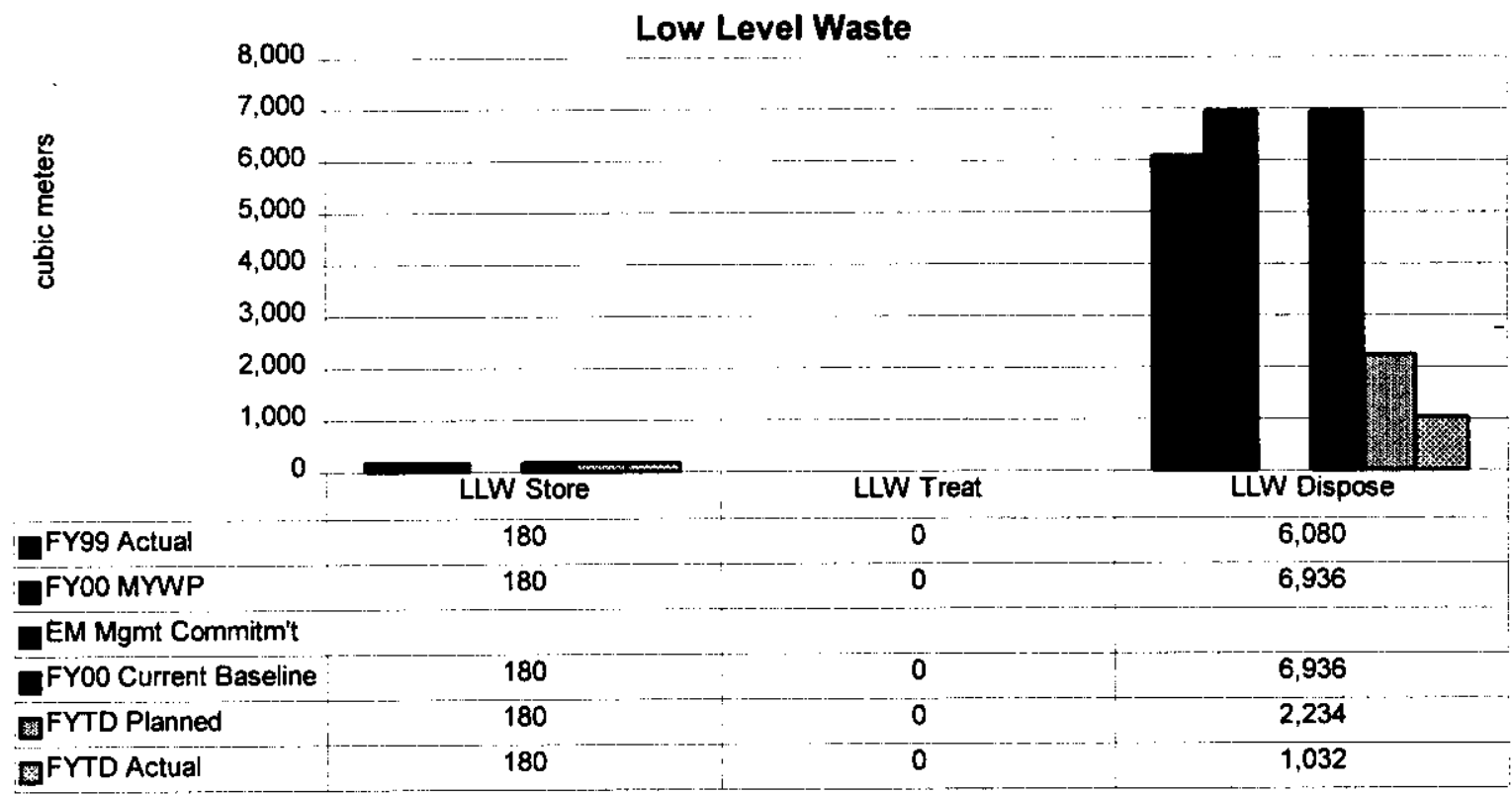

Storage: Storage remains unchanged for LLW not suitable for disposal. Contracting for commercial treatment of this waste is planned for FY2007.

Treatment: No treatment of LLW is planned until after FY2006 when a treatment alternative has been selected. All newly generated LLW receipts are prepared and packaged to the waste acceptance criteria for disposal of LLW in the burial grounds and no further treatment is required.

Disposal: LLW shipments from Argonne National Laboratory and Battelle Columbus originally planned for the first quarter have been rescheduled to the last 3 quarters. 
Environmental Management Performance Report-December 1999

Section B: 2 - Analytical Services
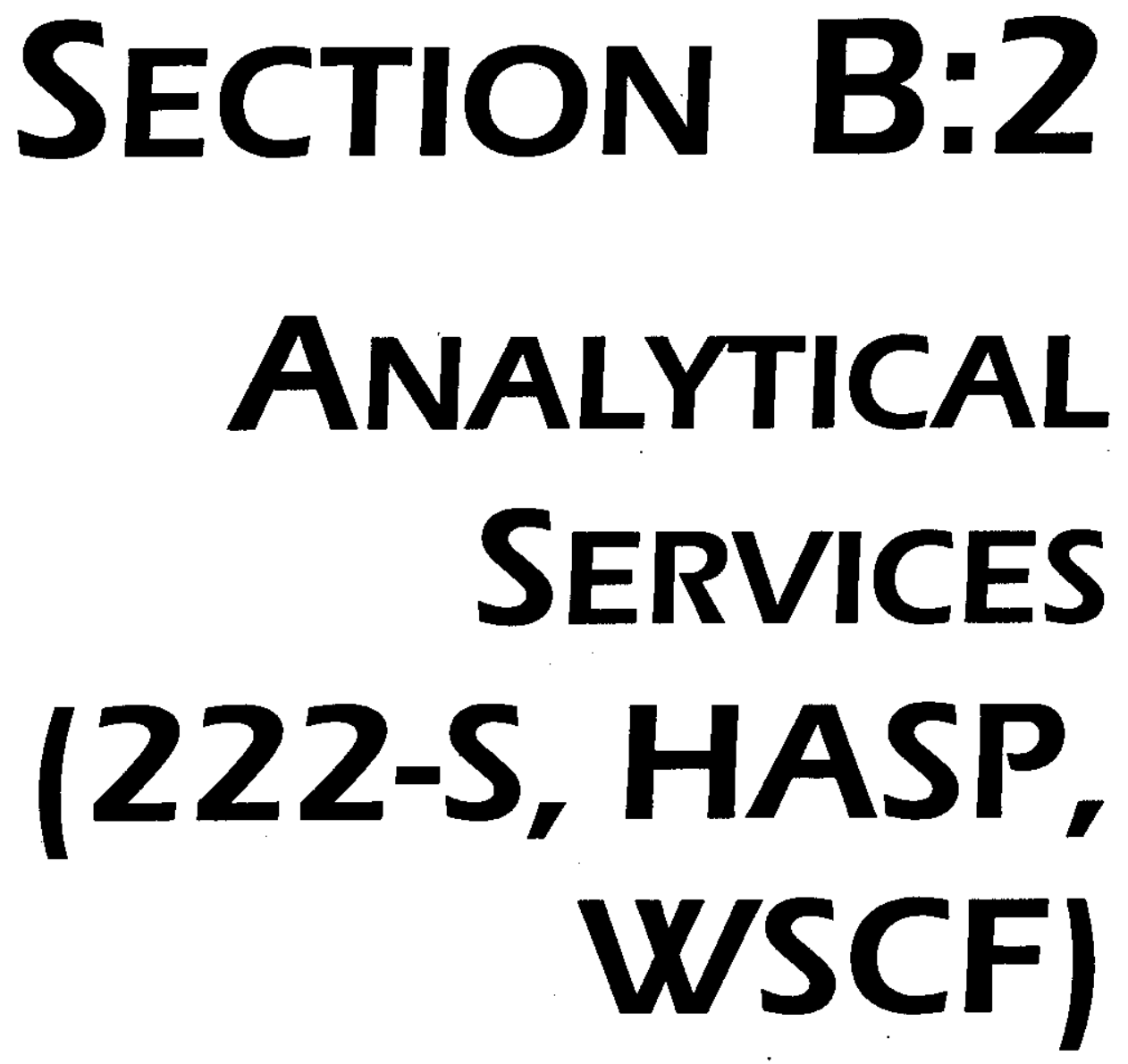

As OF DECEMBER 31, 1999

PROJECT MANAGERS

S. H. Wisness, RL

Phone: (509) 373-9337

D.L. Renberger, FH

Phone: (509) 372-0877 


\section{SUMMARY}

Analytical Services [222-S, Hanford Analytical Services Program (HASP), Waste Sampling and Characterization Facility (WSCF)] consists of Analytical Services, PBS WM06, WBS 1.2.4.

DOE Richland Operations Manager Keith Klein toured the Waste Sampling and Characterization Facility (WSCF) and the 222-S Laboratory. At WSCF, Klein recognized the facility's six years without a lost day of work due to injury, since opening in October 1993.

Preparations were conducted for headspace gas sampling and analysis of 5 TRU waste containers planned for early January 2000. A case narrative was built to validate the adequacy of the previously analyzed 107 drums. The data report will support the January 24, 2000 Carlsbad Area Office audit of Hanford's TRU Program WIPP certification. Technical issues related to Field Reference Standard Certification of Summa Canister Assemblies (SCA) have been successfully resolved.

Facility Evaluation Board (FEB) records and data were gathered in preparation for the FEB assessment January 17-28,2000. The requested documentation will be delivered to FEB on January 4,2000 . A new process in providing documentation is being "piloted" with FEB concurrence. In addition to hard copy documentation, an electronic table with hyperlinks to all information that is electronically available will be provided to the FEB. This will not only eliminate a large amount of copying, but also provide ease of access from any FEB workstation.

Milestone performance (EA, DOE-HQ and RL) shows no milestones are due this reporting period.

\section{ACCOMPLISHMENTS}

- $\quad$ Performed 1.2 Analytical Equivalency Units (AEU) (FYTD) through December 1999 at the 222-S Laboratory in support of the RPP (TWRS) tank characterization program as planned. Completed final analytical reports on RPP Tanks S-111 (grab), AP-103 (grab) and TX-113 (core) as planned.

- $\quad$ Performed 2,700 analyses (FYTD) through December 1999 at WSCF for a wide variety of customers as planned.

- $\quad$ The 222-S Laboratory successfully completed the EPA/ERA Water Pollution (WP) Performance Evaluation (PE) samples and received a perfect score of $100 \%$, with all thirty-five parameters within EPA/ERA established criteria.

- $\quad$ AS is actively participating in DOEs National Analytical Manager Program (NAMP) to develop a complex-wide auditing program for analytical laboratory services. 
- Visual checks of stacks at the 222-S Laboratory Complex and the WSCF were performed to detect evidence of cracking or other signs of structural problems. The State of Washington Department of Health $(\mathrm{DOH})$ required these visual checks of site stacks as a result of the discovery of cracks in the B Plant Canyon exhaust ductwork. The visual check revealed problems with the 222-S main stack ductwork.

- The reissued WMP/ASP ISMS Program Plan was approved and issued, which supports plans to declare readiness for ISMS verification by April 28, 2000.

\section{Cost Performance (\$M):}

\begin{tabular}{|l|c|c|c|}
\hline & BCWP & ACWP & VARIANCE \\
\hline Analytical Services & $\$ 5.8$ & $\$ 6.4$ & $-\$ 0.6$ \\
\hline
\end{tabular}

The $\$ 0.6$ million (10.3 percent) unfavorable cost variance is primarily due to the approved initiation of the FY 1999 carryover work scope, and the incremental cost of 222-S Laboratory tank 104 polychlorinated biphenyl recovery activities. Further information at the PBS level can be found in the following Cost Variance Analysis details.

\section{Schedule Performance (\$M):}

\begin{tabular}{|l|c|c|c|}
\hline & BCWP & BCWS & VARIANCE \\
\hline Analytical Services & $\$ 5.8$ & $\$ 5.9$ & $-\$ 0.1$ \\
\hline
\end{tabular}

The $\$ 0.1$ million (1.7 percent) unfavorable schedule variance is within established threshold.

\section{ISSUES}

The WSCF laboratory self-identified an analytical procedure where acid digestion of certain liquid samples was not conducted per permit-mandated protocol.

Strategy/Status: The procedure was revised and reanalysis completed for 200 and 300 Area customers. Analysis of historical analytical data for RCRA samples shows that approximately $80 \%$ were digested (microwave, closed vessel) prior to analysis. A draft "white paper" describing the comparison of digested vs. undigested water samples analyzed by ICP-MS has been completed and will be issued the first week in January. The white paper will included a section on "lessons learned". 


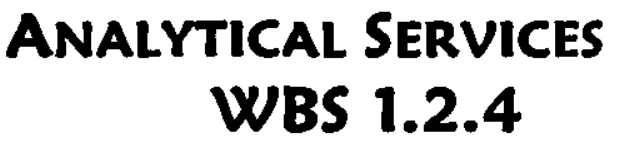

FY 2000 COST/SCHEDULE PERFORMANCE - ALL FUND TYPES

\section{Cumulative to Date Status}
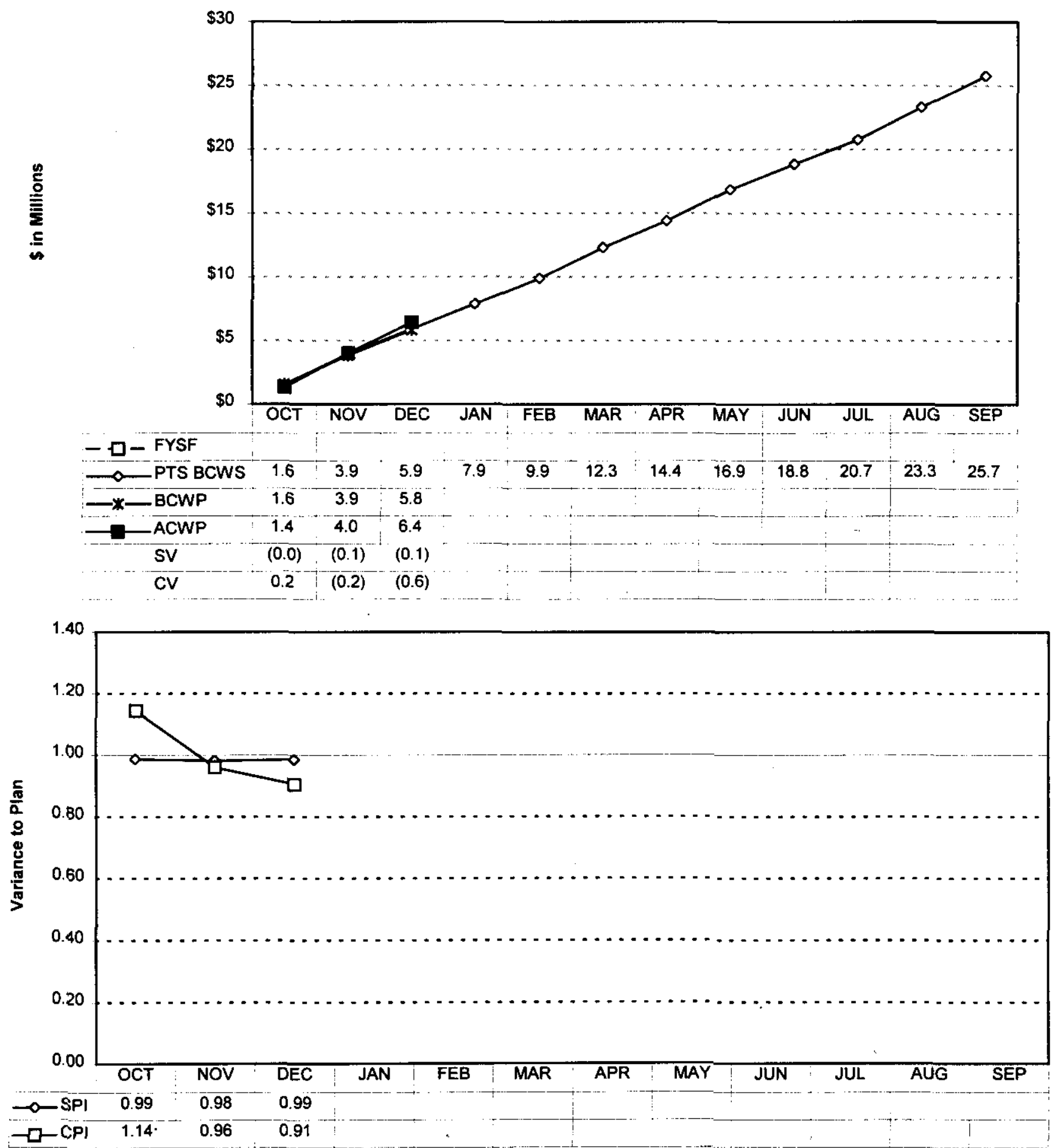


\section{ANALYTiCAL SERVices \\ WBS 1.2.4}

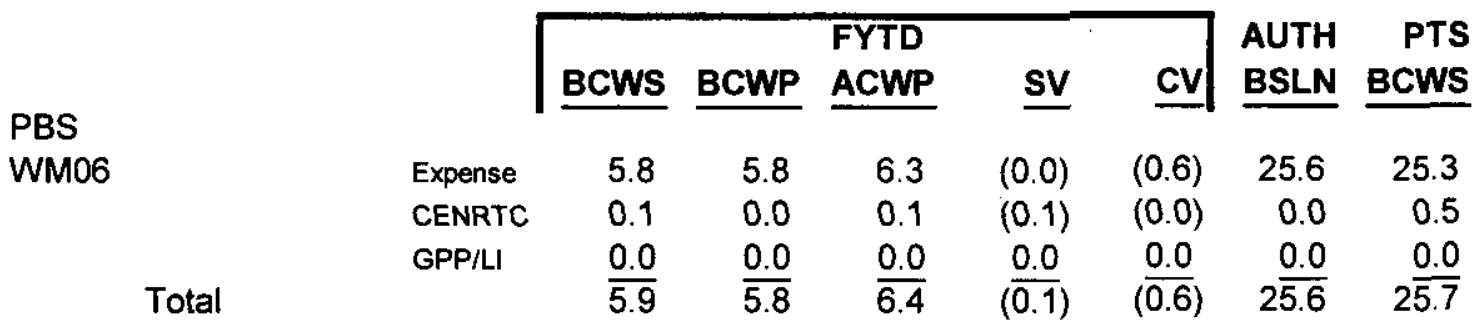

S In Millions

\section{COST VARIANCE ANALYSIS: $(-\$ 0.6 \mathrm{M})$}

\section{WBS/PBS}

\subsection{4/WM06}

1.2.4/WMO6 Calycal Services initiation of the FY 1999 carryover work scope, and the incremental cost of 222-S Laboratory tank 104 polychlorinated biphenyl recovery activities. Also contributing to the overrun are increased costs for development and implementation of chemical technologist training, health physics support to operations, and Integrated Environmental Safety and Health Management System (ISMS) implementation.

Impact: Current spending forecasts indicate a potential yearend overrun in this PBS. Corrective Action: The FY 1999 carryover baseline change request is expected to be approved and implemented in January which will partially negate the overrun position. The forecasted spending projection will continue to be monitored and appropriate corrective actions identified and implemented to alleviate projected yearend overruns.

\section{SChedule VARIance ANAlysis: (-\$0.1)}

\subsection{4/WM06 Analytical Services}

Description /Cause: The unfavorable schedule variance of \$0.1M (1.5 percent) is within established threshold.

Impact: None

Corrective Action: None required. 
Environmental Management Performance Report $-10 \mathrm{~d}$

Section B: 2 -Analytical Services (222-S, HA ASP, WSCF

\section{ANALYTICAL SERVICES - WBS 1.2.4 MILESTONE ACHIEVEMENT}

\begin{tabular}{|c|c|c|c|c|c|c|c|c|}
\hline \multirow[b]{2}{*}{ MILESTONE TYPE } & \multicolumn{4}{|c|}{ FISCAL YEAR-TO-DATE } & \multicolumn{3}{|c|}{ REMAINING SCHEDULED } & \multirow[b]{2}{*}{$\begin{array}{c}\text { TOTAL } \\
\text { FY } \\
2000\end{array}$} \\
\hline & $\begin{array}{c}\text { Completed } \\
\text { Early }\end{array}$ & $\begin{array}{c}\text { Completed } \\
\text { On } \\
\text { Schedule }\end{array}$ & $\begin{array}{c}\text { Completed } \\
\text { Late }\end{array}$ & Overdue & $\begin{array}{c}\text { Forecast } \\
\text { Early }\end{array}$ & $\begin{array}{c}\text { Forecast } \\
\text { On } \\
\text { Schedule }\end{array}$ & $\begin{array}{c}\text { Forecast } \\
\text { Late }\end{array}$ & \\
\hline Enforceable Agreemen & 0 & 0 & 0 & 0 & o & 0 & 0 & 0 \\
\hline DOE-HQ & 0 & 0 & 0 & 0 & 0 & 0 & 0 & 0 \\
\hline $\mathrm{FO}$ & 0 & 0 & 0 & 0 & $\overline{0}$ & 0 & 0 & 0 \\
\hline $\mathrm{RL}$ & 0 & $\overline{0}$ & 0 & 0 & $\overline{0}$ & 1 & $\overline{0}$ & 1 \\
\hline Total Project & 0 & 0 & 0 & 0 & 0 & 1 & 0 & 1 \\
\hline
\end{tabular}

\section{MILESTONE EXCEPTION REPORT}

\begin{tabular}{|c|c|}
\hline Number/NBBS LeveI & Milestone Title \\
\hline
\end{tabular}

\section{OVERDUE - 0}

FORECAST LATE - 0 

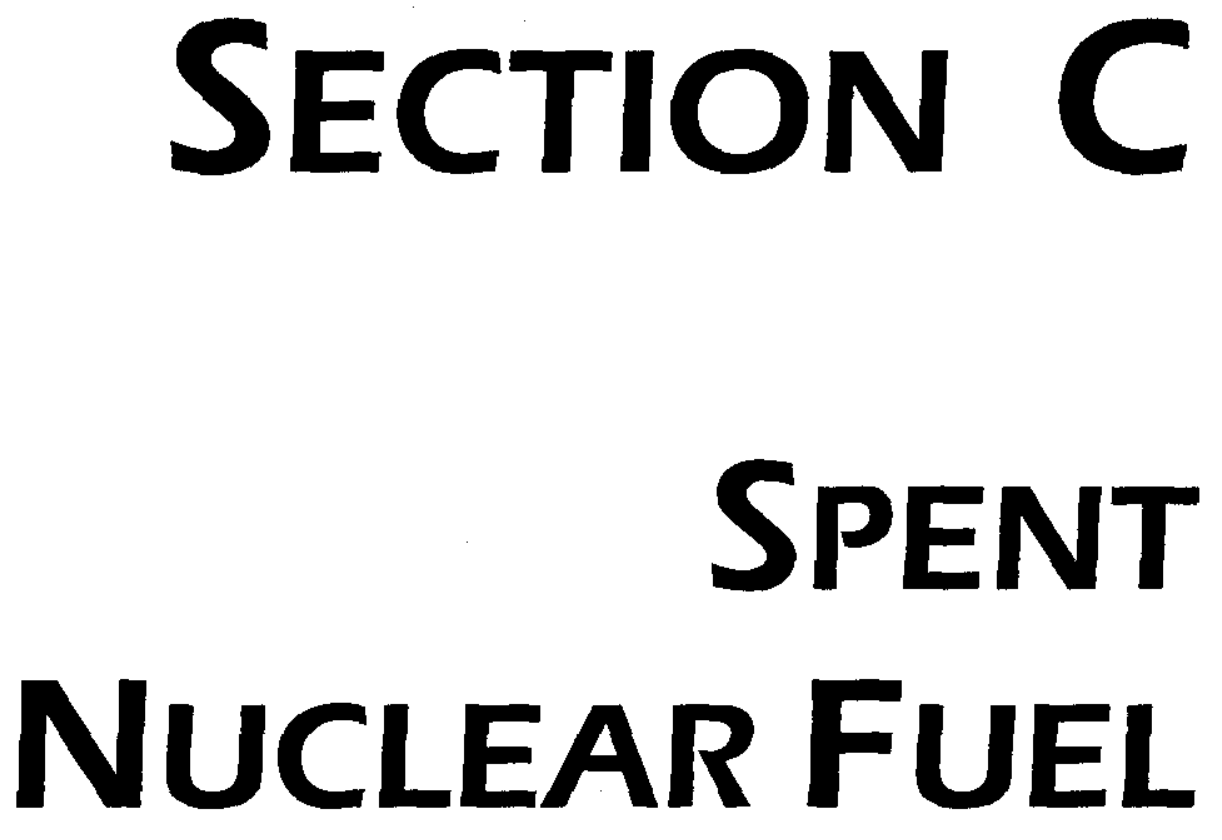

\title{
As OF DECEMBER 31, 1999
}

PROJECT MANAGERS

\author{
P. G. Loscoe, RL \\ Phone: (509) 373-7465
}

R. B. Wilkinson, FH

Phone: (509) 372-3030 


\section{Summary}

The Spent Nuclear Fuel (SNF) mission consists of the Spent Nuclear Fuel Project WBS 1.3.1.1 (Project Baseline Summary [PBS] WM01) and the subsequent Canister Storage Building (CSB) Operations Project WBS 1.3.2.1 (PBS WM02), which doesn't start until FY 2004.

The Canister Storage Building (CSB) is 94 percent complete, compared to 96 percent planned. The Cold Vacuum Drying (CVD) Facility is 92 percent complete compared to 94 percent planned.

The SNF Project continued testing of energized components (i.e., calibration, loop tests, equipment approach) at the Cold Vacuum Drying (CVD) Facility. RL issued the Safety Evaluation Report for the CVD Annex to SNF Project FSAR with conditions for approval.

Fabrication of production Multi-Canister Overpacks (MCO) and MCO baskets continued at Joseph Oat, Inc. and the Hanford Site respectively.

Preparations continued for initiation of cold testing of the K West Basin Fuel Retrieval System and Integrated Water Treatment System. The contractor management review indicated systems were not ready to initiate testing on December 31,1999 , as had been planned. Reinitiating of the management review in late January 2000 is anticipated, pending resolution of identified deficiencies.

Fiscal year-to-date milestone performance (EA, DOE-HQ, and RL) shows one of one milestones (100 percent) is overdue. The Milestone Achievement details, found following cost and schedule variance analysis, provide further information on all milestone types.

\section{Accomplishments}

- $\quad$ CSB project is 94 percent complete vs. 96 percent planned.

- CVD Facility is 92 percent complete vs. 94 percent planned.

- $\quad$ The Safety Evaluation Report (SER) for the CVD Annex for the SNF Project FSAR was issued by RL, with conditions for approval, as scheduled.

- Installation of drain valve covers was completed at the $\mathrm{K}$ Basins and associated Unresolved Safety Questions (USQs) were closed. 


\section{Cost Performance $(\$ M)$ :}

\begin{tabular}{|l|c|c|c|}
\hline & BCWP & ACWP & VARIANCE \\
\hline Spent Nuclear Fuels & $\$ 33.8$ & $\$ 44.6$ & $-\$ 10.8$ \\
\hline
\end{tabular}

The $\$ 10.8$ million (31.9 percent) unfavorable cost variance is primarily a result of Cold Vacuum Drying engineering and testing costs higher than planned; startup and testing activities; Safety Analysis Reports and K Basin KE Facility Modifications cost overruns.

\section{Schedule Performance (\$M):}

\begin{tabular}{|l|c|c|c|}
\hline & BCWP & BCWS & VARIANCE \\
\hline Spent Nuclear Fuels & $\$ 33.8$ & $\$ 43.5$ & $-\$ 9.7$ \\
\hline
\end{tabular}

The $\$ 9.7$ million (22.3 percent) unfavorable schedule variance is due primarily to Facility Modifications KE Construction; Canister Storage Building Construction Contract; K Basin Modular Office Trailers and Integrated Water Treatment System KE Construction.

\section{Issues}

MCO Quality Assurance Requirements: The U.S. Department of Energy, Richland Operations Office (RL) provided direction to Fluor Daniel Hanford, Inc. to include the Multi-Canister Overpacks (MCOs) and the MCO baskets on the Hanford Site's Office of Civilian Radioactive Waste Management Quality Assurance program Q-List. The additional quality assurance requirements will affect the cost but will not have any impact on the schedule for fabrication of the $\mathrm{MCO}$ and baskets.

Strategy/Status: Baseline change requests have been developed to define the impacts and to provide the authorization to place the MCOs and the MCO baskets on the Q-List. The BCRs are in the approval process. Clear definition of the SNF Project's interpretation of required actions to satisfy the RL guidance has been documented to RL. Effected implementation date to satisfy OCRWM QARD requirements for new work is March 8, 2000. 


\section{Spent Nuclear Fuels WBS 1.3}

FY 2000 COST/SCHEDULE PERFORMANCE - ALL. FUND TYPES Cumulative to Date Status
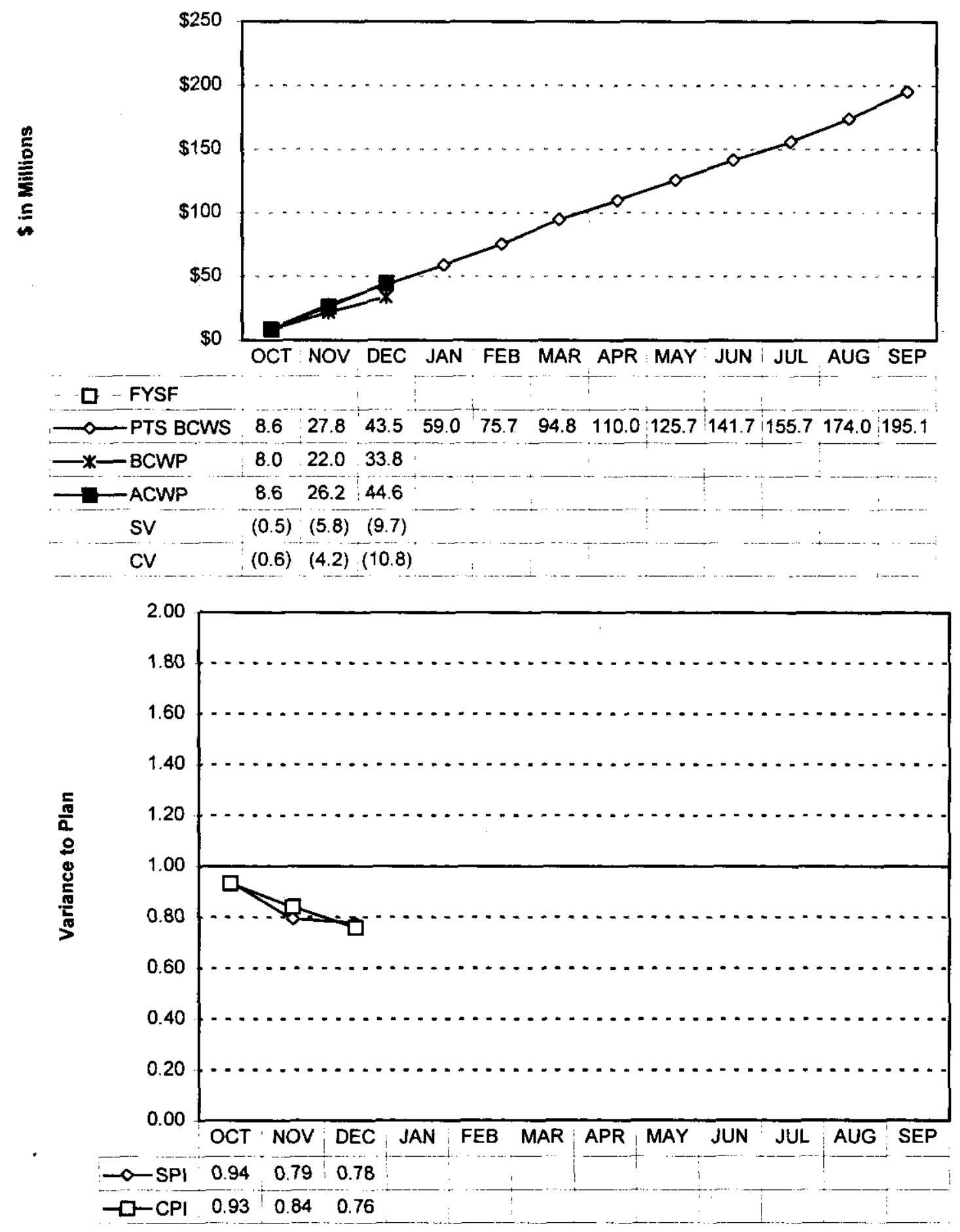


\section{Spent Nuclear Fuels \\ WBS 1.3}

1.3

PBS

WM01

Spent Nuclear Fuel

Sub-Total WMO1

WM02

Storage Canister

Sub-Total WM02

Total

Total

$\begin{array}{lrrr}\text { Expense } & 31.5 & 27.7 & 33.2 \\ \text { CENRTC } & 4.7 & 1.7 & 3.1 \\ \text { GPPILI } & 7.3 & 4.4 & 8.2 \\ & 43.5 & 33.8 & 44.6\end{array}$

\section{FYTD}

BCWS

Expense
CENRTC
GPP/LI

Expense

CENRTC

GPP/LI
43.5

31.5

4.7

7.3

43.5

0.0

0.0

e. 0

0.0

27.7

1.7

4.4

33.8

0.0

0.0

0.0

0.0

33.8

\section{ACWP}

33.2

3.1

8.2

44.6

0.0

0.0

0.0

0.0

sV

cy

(3.8)

(5.6)

(3.0)

(1.4)

(2.9)

(9.7)

(3.8)

(10.8)

AUTH

BSLN BCWS

PTS

$\begin{array}{llll}0.0 & 0.0 & 0.0 & 0.0\end{array}$

$\begin{array}{llll}0.0 & 0.0 & 0.0 & 0.0\end{array}$

0.0

0.0

0.0

0.0

0.0

0.0

0.0

\$ In Millions 


\section{COST VARIANCE ANALYSIS: $(-\$ 10.8 M)$}

\section{WBS/PBS $\quad \underline{\text { Title }}$}

\subsubsection{1/WM01 Spent Nuclear Fuel}

Description and Cause: Of the $\$ 10.8$ (31.9 percent) million unfavorable variance, $\$ 3.3$ million is due to engineering and testing costs for the Cold Vacuum Drying Facility exceeding plan; $\$ 1.4$ million for startup and testing activities; $\$ 1.2$ million for Safety Analysis Reports not budgeted in FY 2000 and $\$ .9$ million for (K Basin Facility modifications overrun resulting from KE mezzanine) removal punchlist items, panel 9 installation and MEI reroute.

Impact: These overruns were anticipated changes foreseen during the contingency analysis and will be allocated through baseline change control. Essentially all contingency will be utilized. Corrective Actions: SNF Project will continue to look at cost efficiencies to replenish contingency.

\section{SCHEDULE VARIANCE ANALYSIS: $(-\$ 9.7 \mathrm{M})$}

\section{WBS/PBS $\quad$ Title}

\subsubsection{1/WM01 Spent Nuclear Fuel}

Description and Cause: Of the $\$ 9.7$ million (22.3 percent) unfavorable schedule variance, $\$ 2.5$ million is due to $\mathrm{KE}$ Construction of the Facility Modifications resulting from resources to support KW Punchlist \& Testing; \$2.2 million for the Canister Storage Building Construction Contract is inconsistent with baseline, but meets end date; 1.1 million for the Modular office trailer behind schedule (no impact); and $\$ 0.7$ million for Integrated Water Treatment System KE construction due to design/fabrication rebid.

Impacts: All projects continue to support the fuel move date of November 30, 2000. Deliveries will support Tri-Party Agreement dates. Although variances are not currently negatively affecting planned fuel movement; negative impacts could result if work around plans are not accomplished.

Corrective Actions: SNF Project is developing, analyzing, and implementing recovery plans designed to mitigate schedule variances. All recovery plans support the November 2000 fuel movement milestone. 


\section{Spent Nuclear Fuels - WBS 1.3 \\ Milestone Achievement}

\begin{tabular}{|c|c|c|c|c|c|c|c|c|}
\hline \multirow[b]{2}{*}{ MILESTONE TYPE } & \multicolumn{4}{|c|}{ FISCAL YEAR-TO-DATE } & \multicolumn{3}{|c|}{ REMAINING SCHEDULED } & \multirow[b]{2}{*}{$\begin{array}{c}\text { TOTAL } \\
\text { FY } \\
2000\end{array}$} \\
\hline & $\begin{array}{c}\text { Completed } \\
\text { Early }\end{array}$ & $\begin{array}{c}\text { Completed } \\
\text { On } \\
\text { Schedule }\end{array}$ & $\begin{array}{c}\text { Completed } \\
\text { Late }\end{array}$ & Overdue & $\begin{array}{c}\text { Forecast } \\
\text { Early }\end{array}$ & $\begin{array}{c}\text { Forecast } \\
\text { On } \\
\text { Schedule }\end{array}$ & $\begin{array}{c}\text { Forecast } \\
\text { Late }\end{array}$ & \\
\hline Enforceable Agreement & 0 & 0 & 0 & 0 & 0 & 2 & 0 & 2 \\
\hline DOE-HQ & 0 & 0 & of & 0 & 0 & 0 & 0 & 0 \\
\hline $\mathrm{RL}$ & 0 & 0 & 0 & 1 & 0 & 4 & 0 & 5 \\
\hline Total Project & 0 & 0 & 0 & 1 & 0 & 6 & 0 & 7 \\
\hline
\end{tabular}

\section{MILESTONE EXCEPTION REPORT}

\begin{tabular}{|c|c|}
\hline Number/WBS Level & Milestone Title \\
\hline
\end{tabular}

\section{Overdue - 1}

S07-97-053 RL CSB FSAR and Project FSAR Approval $\quad 12 / 21 / 1999 \quad 03 / 01 / 00$

\subsection{1}

Cause: Changes in strategy of controls of the Multi-Canister Overpack Handling Machine due to electrical separations issues.

Impact: No impacts to limiting path activities.

Corrective Action: BCR SNF-2000-002 has been issued for approval. This change request will modify the baseline schedule to reflect a new FSAR approval date.

\section{Forecast Late - 0}



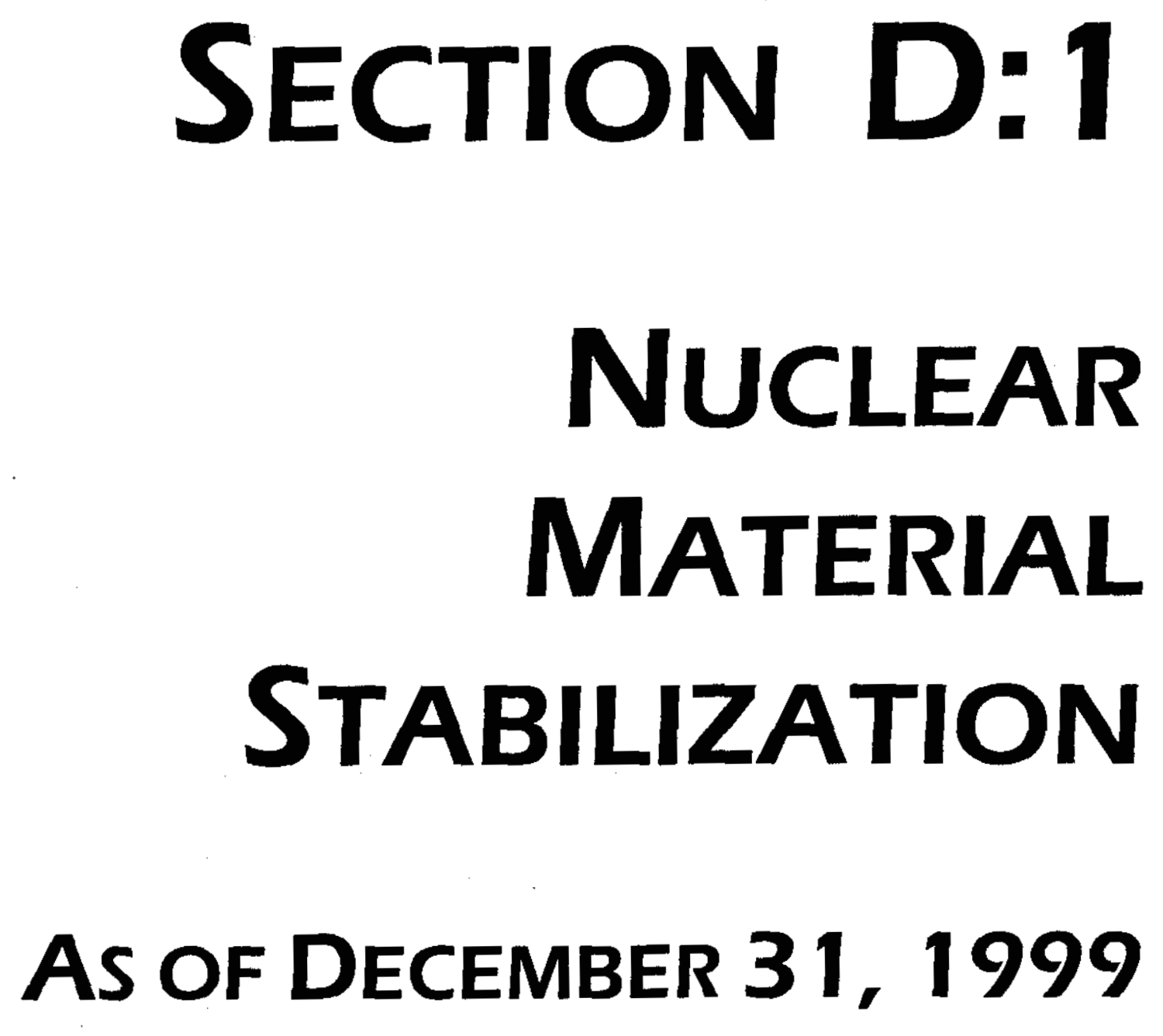

PROJECT MANAGERS

P. M. Knollmeyer, RL
Phone: (509) 376-7435

L. J. Olguin, FH

Phone: (509) 372-8233 


\section{SUMMARY}

The Nuclear Material Stabilization mission consists of the Plutonium Finishing Plant (PFP), WBS 1.4.5, PBS TP05.

As of December 1999 a total of 164 cans of Plutonium oxides and sludges have been stabilized through thermal stabilization (69 items in December 1999). By month's end, a total of 13 liters of Plutonium nitrate solution have been stabilized in the prototype vertical denitration calciner.

Fiscal-year-to-date milestone performance (EA, DOE-HQ, and RL) shows that two milestones (67 percent) were completed on or ahead of schedule, no milestones were completed late, and one (33 percent) is overdue. Milestone (TRP-00-500) is late due to a proposed change in process implementation. A letter was sent to RL indicating the milestone would not be met. Further details can be found in the milestone exception report following the cost and schedule variance analysis.

\section{ACCOMPLISHMENTS}

- Plutonium Oxide Stabilization - A total of 164 cans of oxides/sludges have been stabilized (69 items in December 1999).

- Plutonium Nitrate Solution Stabilization - A total of 13 liters of solution have been stabilized. The magnesium hydroxide precipitation glovebox fabrication is proceeding on schedule.

- Plutonium Polycube stabilization - A decision to perform direct thermal stabilization in lieu of pyrolysis followed by thermal stabilization was made and documented via a letter issued December 30, 1999.

- Project W-460 - The contract for the Bagless Transfer System Glovebox has been issued. Delivery of this system to Hanford is expected two weeks ahead of schedule.

\section{Cost Performance (\$M):}

\begin{tabular}{|l|c|c|c|}
\hline & BCWP & ACWP & VARIANCE \\
\hline Nuclear Material Stabilization & $\$ 27.3$ & $\$ 21.8$ & $\$ 5.4^{*}$ \\
\hline
\end{tabular}

*Rounding

The $\$ 5.4$ million (19.8 percent) favorable cost variance is due to a shortage of staff, a lag in costs for contracts [(e.g., including the Energy Services contract for steam, $\mathrm{Mg}(\mathrm{OH})^{2} \mathrm{Glovebox}$, etc], slow start in definitive design support for Project W-460 and delay in contract release for the Bagless Transfer System (BTS) procurement. Developed work-around with DOE Savannah River Site to recover schedule from late award of contract which delivers the BTS to Hanford two weeks early, due to arrive the first week of June 2000 . 


\section{SChedule Performance (\$M):}

\begin{tabular}{|l|c|c|c|}
\hline & BCWP & BCWS & VARIANCE \\
\hline Facility Stabilization & $\$ 27.3$ & $\$ 30.6$ & $-\$ 3.3$ \\
\hline
\end{tabular}

The $\$ 3.3$ million (10.8 percent) unfavorable schedule variance is primarily due to the behind status in special projects (sanitary water system upgrade, Criticality Alarm Panel upgrade and radiation monitoring constant air monitor upgrade); and the definitive design delay on Project W460. Further details provided in the Schedule Variance Analysis section.

\section{ISSUES}

Loss of electrical transformer capacity (two of four transformers supplying power to the PFP failed in November 1999). The remaining two transformers show the same signs of degradation as the failed units.

Strategy/Status: Temporary transformers have been located and are being installed. Currently working to identify recommended path forward to ensure continued electrical capacity. 


\section{Nuclear Materials Stabilization Project WBS 1.4.5}

\section{FY 2000 COST/SCHEDULE PERFORMANCE - ALL FUND TYPES}

Cumulative to Date Status
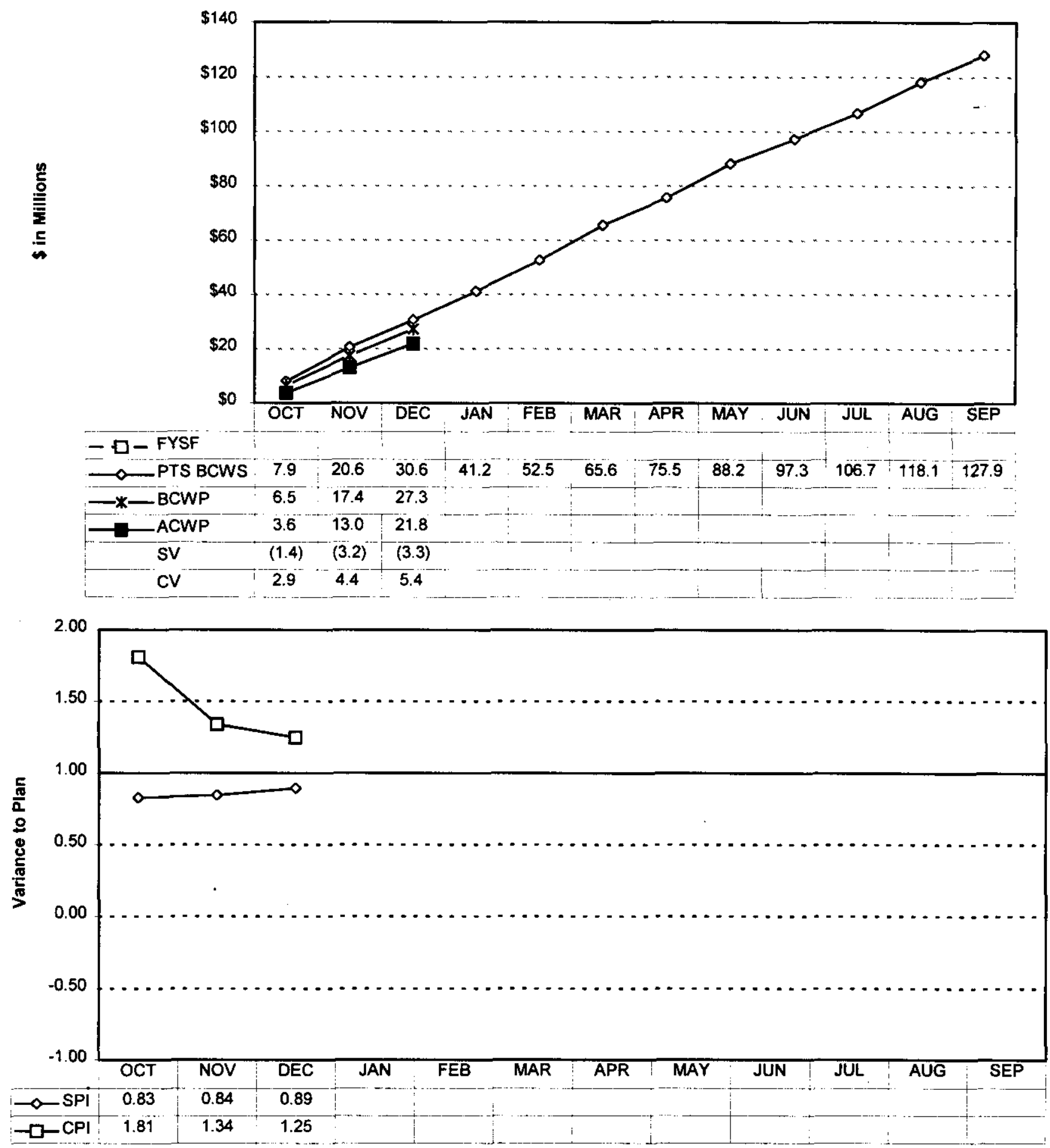
Nuclear Materials Stabilization Project

WBS 1.4.5

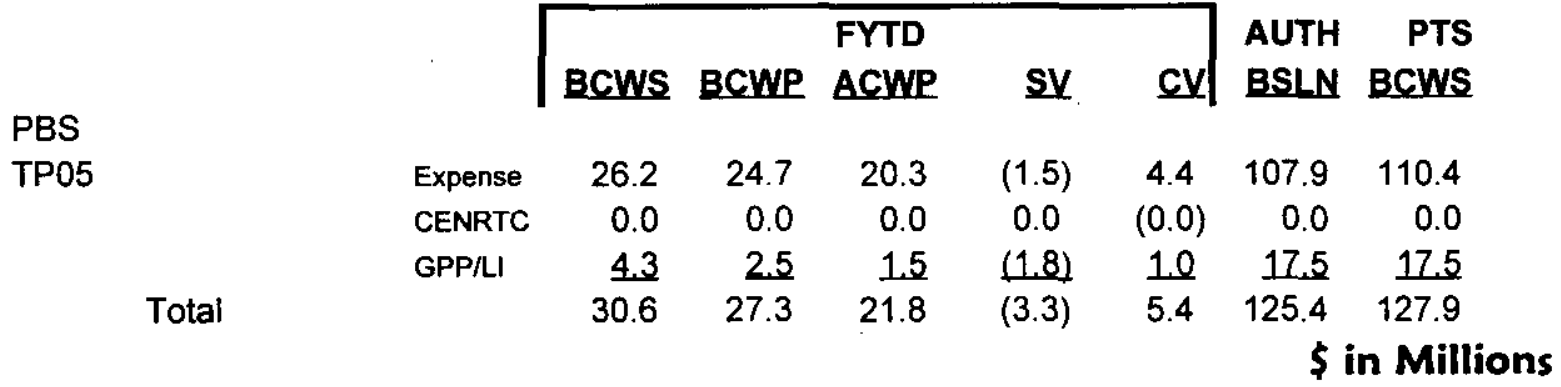

RL-Directed costs (steam) are included in the PTS BCWS.

\section{COST VARIANCE ANALYSIS: $(+\$ 5.4 \mathrm{M})$}

\section{WBS/PBS}

\subsection{5/TP05}

Description and Cause: The $\$ 5.4$ million favorable cost variance is due to a shortage of staff FY2000 resulting from suspended hiring in FY1999 due to budget constraints, lag in costs for contracts (i.e., including the Energy Services contract for steam), and delay in contract release for the BTS glove box procurement.

Impact: No impact. The favorable cost variance will self correct once contract costs/accruals align.

Corrective Action: Numerous contracts have been issued to correct for staff shortage. Also, staff hiring has been expedited.

\section{SCHEDULE VARIANCE ANALYSIS: (-\$3.3)}

\section{WBS/PBS}

\subsection{5/TP05}

Description and Cause: The unfavorable schedule variance is due primarily to: 1) Min-safe activities are behind schedule $<\$ 606 \mathrm{~K}>$ on projects such as sanitary water system (must wait for warmer weather), Cost Air Monitor (CAM) replacements (CAMs on order but not arrived) and the criticality alarm panel upgrades (budget front-loaded) awaiting available time for craft support; 2) Stabilize Polycubes shows behind schedule $<\$ 497>$ because project being statused against original baseline yet working on new path forward with an approved AWA; 3) Stabilize Residues behind $<\$ 416>$ due to the same reason as polycubes; 4 ) Disposition of Nuclear Materials behind schedule $<\$ 858>$ because resources have been used in supporting stabilization efforts; and 5) Project W-460 behind schedule $<\$ 1,947>$ due to facility mod construction not started awaiting design, procurements (NDA lab equipment, trailer installation, and Outer Can Welder) delayed. The negative schedule variances are somewhat offset by ahead of schedule status (\$2106) for metal stabilization. Schedule recovery on all activities is in work.

Impact: There is no long term impact from the behind schedule status on either the Special Project or Project W-460 definitive design activities as the schedule is anticipated to be recovered.

Corrective Action: Special projects and definitive design being worked to recover schedule. 


\section{NUCLEAR MATERIAL STABILIZATION - WBS 1.4.5 MILESTONE ACHIEVEMENT}

\begin{tabular}{|c|c|c|c|c|c|c|c|c|}
\hline \multirow[b]{2}{*}{ MILESTONE TYPE } & \multicolumn{4}{|c|}{ FISCAL YEAR-TO-DATE } & \multicolumn{3}{|c|}{ REMAINING SCHEDULED } & \multirow[b]{2}{*}{$\begin{array}{l}\text { TOTAL } \\
\text { FY } 2000\end{array}$} \\
\hline & $\begin{array}{c}\text { Completed } \\
\text { Early }\end{array}$ & $\begin{array}{c}\text { Completed } \\
\text { On } \\
\text { Schedule }\end{array}$ & $\begin{array}{c}\text { Completed } \\
\text { Late }\end{array}$ & Overdue & $\begin{array}{l}\text { Forecast } \\
\text { Early }\end{array}$ & $\begin{array}{l}\text { Forecast } \\
\text { On } \\
\text { Schedule }\end{array}$ & $\begin{array}{c}\begin{array}{c}\text { Forecast } \\
\text { Late }\end{array} \\
\text { L }\end{array}$ & \\
\hline Enforceable Agreement & & & 0 & 0 & 0 & & 0 & \\
\hline DOE-HQ & 0 & & 0 & 1 & 0 & 0 & 0 & \\
\hline$R_{L}$ & 1 & 0 & 0 & 0 & 0 & 10 & 0 & 1 \\
\hline Total Project & 2 & 0 & 0 & 1 & 0 & 11 & 0 & 12 \\
\hline
\end{tabular}

\section{Total Project}

Completed Early $67 \%$

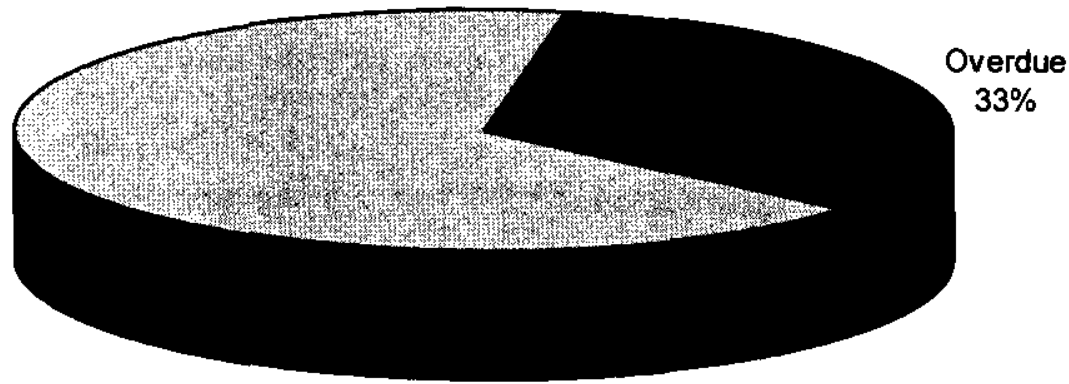




\section{MILESTONE EXCEPTION REPORT}

\begin{tabular}{|c|c|}
\hline Number/WBS Level & Milestone Title \\
\hline
\end{tabular}

\section{OVERDue - 1}

TRP-00-500 HQ

1.4.5
Install Two LANL Pyrolysis Units for

Stabilization of Polycubes
12/31/99 Proposed

Deletion

Cause: An alternative path forward using muffle furnaces for stabilization of polycubes has been recommended. A letter was issued to Department of Energy, Richland Office (DOE-RL) stating this Defense Nuclear Facility Safety Board milestone would not be met.

Corrective Action: Thermal stabilization testing at Hanford's Pacific Northwest National Laboratory and Plutonium Finishing Plant's Plutonium Process Support Laboratory is underway with an approved Advanced Work Authorization. A baseline change request is being prepared to document changes.

\section{FY 1999 OVERDUE - 2}
TRP-99-419 HQ
Complete Installation of Production
$09 / 30 / 99$
Proposed
1.4.5
Scale Vertical Calciner
Deletion

Cause: The production scale vertical calciner has been replaced with the Magnesium Hydroxide Precipitation process.

Impact: No impact. This milestone is obsolete.

Corrective Action: Since installation and testing of the production scale vertical calciner is an EM-65 Management Commitment, the Department of Energy, Richland Office (DOE-RL) change control process cannot remove this milestone.
TRP-99-500 HQ
Complete Installation \& Testing of
$09 / 30 / 99$
Proposed
1.4.5
Production Vertical Calciner
Deletion

Cause: The production scale vertical calciner has been replaced with the Magnesium Hydroxide Precipitation process.

Impact: No impact. This milestone is obsolete.

Corrective Action: Since installation and testing of the production scale vertical calciner is an EM-65 Management Commitment, the Department of Energy, Richland Office change control process cannot remove this milestone. 


\section{Nuclear Materials Stabilized During the Current Period}

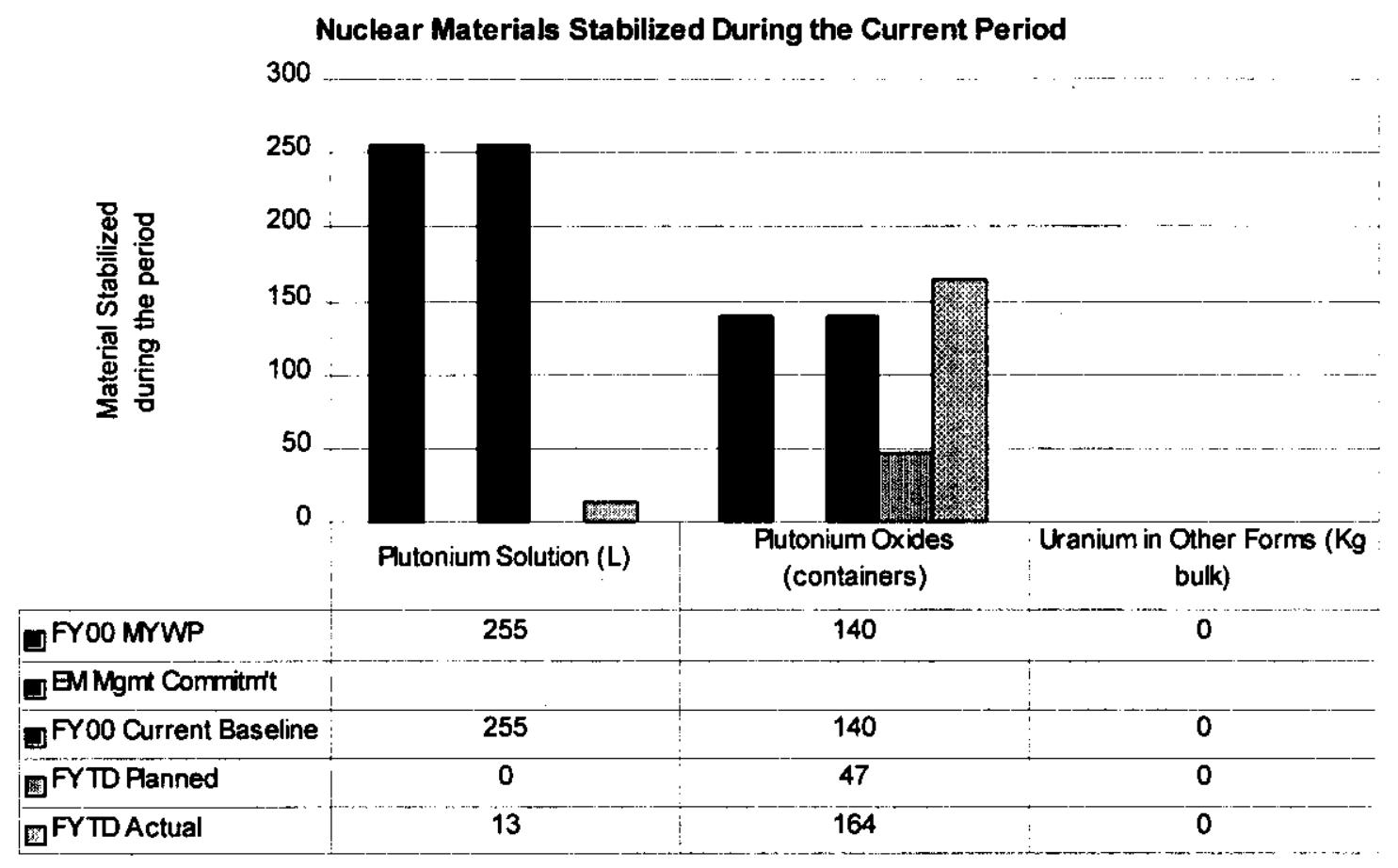

Plutonium Solution: Laboratory testing resulted in early stabilization of 13 liters of Plutonium solution during 1st quarter FY00.

Plutonium Oxides: 164 cans of metal/oxide were stabilized, which exceeds the planned quantity of 47 cans. Metal/oxide stabilization will continue for the next two quarters, whereupon the focus will switch towards stabilization of the solutions. It is currently expected that planned quantities for stabilization of residue, solution and metal/oxide will be met or exceeded for FY00.

Uranium in Other Forms: There is no Uranium inventory. 


\section{BUILDING DEACTIVATION}

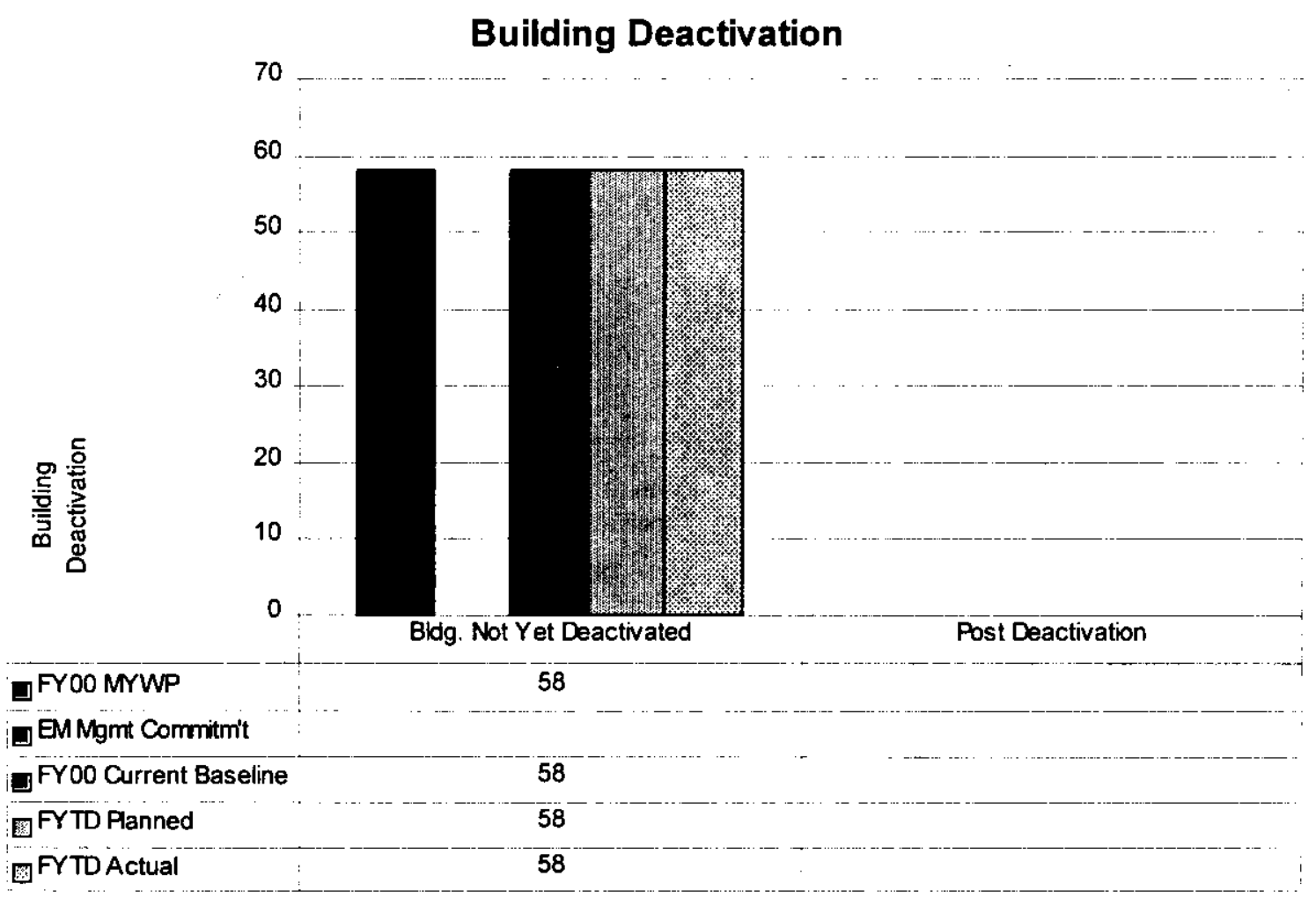

Buildings Not Yet Deactivated: Deactivation of the 58 FYTD actual buildings not yet deactivated will not begin until FY2009 as documented in the Integrated Project Management Plan for the Nuclear Material Stabilization Project.

Post Deactivation: There are no buildings in post deactivation. 

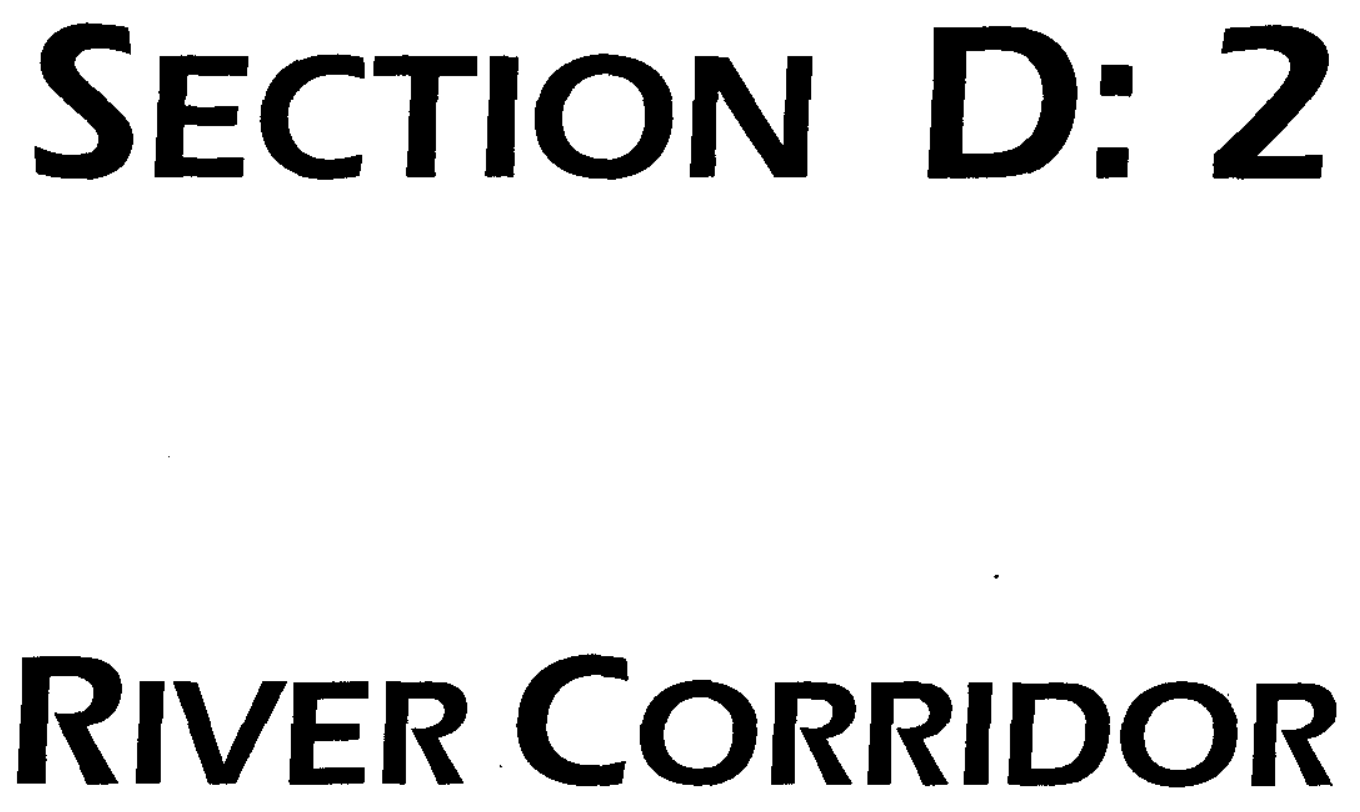

\title{
AS OF DECEMBER 31, 1999
}

PROJECT MANAGERS

\author{
P. M. Knollmeyer, RL \\ Phone: (509) 376-7435
}

N. Boyter, FH Phone: (509) 373-3725 


\section{SUMMARY}

The River Corridor Project consists of the following projects: 300 Area Liquid Effluent Facility (LEF) WBS 1.2.3.2, Project Baseline Summary (PBS) WM05; B-Plant, WBS 1.4.1, PBS TP01; 300 Area/Special Nuclear Materials, WBS 1.4.4, PBS TP04; Transition Project Management, WBS 1.4.6, PBS TP12; Accelerated Deactivation, WBS 1.4.8, PBS TP10; 324/327 Facility Transition, WBS 1.4.10, PBS TP08; and Hanford Surplus Facility Program (300 Area Revitalization), WBS 1.4.11, PBS TP14.

PBS WM05 is divided between WBS 1.2.3.1, Liquid Effluents (200 LEF) and WBS 1.2.3.2, 310 TEDF/340 Facility (300 LEF). The 310 TEDF/340 Facility work scope is now included in the River Corridor Project, whereas the Liquid Effluents (200 LEF) work scope has remained in Waste Management. For the purpose of performance analysis, PBS WM05 is reported in Waste Management, which has the majority of the work scope and funding incorporated in their baseline.

The 300 Area Fuel Supply Shutdown project is on schedule to meet the submittal of the final closure plan due on March 31, 2000. Washington State Department of Ecology (Ecology) approved the changes to the Phase 3 Decontamination Inspection Plan (DIP) and Phase 3 closure field activities associated with the 300 Area Waste Acid Treatment System (WATS) Closure plan.

The Accelerated Deactivation project is making progress towards the planning for the disposition of approximately 1,865 metric tons (MT) of Hanford Unirradiated Uranium. Activities completed to date include the issuance of the Environmental Analysis (EA) for public comment while the Safety Analysis Report for Packaging (SARP) for billet shipment is pending approval by the Department of Energy, Headquarters (DOE-HQ). A white paper on the selection of carbon steel pipe packaging system for 0.95 and 1.25 enriched fuel was also completed. Additionally, a Uranium Disposition Alternatives workshop is scheduled for mid January. Other project progress includes the approval of the 231-Z Safety Analysis and documentation for characterization, allowing characterization work to begin at the $231-Z$ facility.

The National Facility Deactivation Initiative (NFDI) team has been actively participating in several multi-DOE site/contractor activities. They assisted in the development of a Memorandum of Understanding (MOU) between DOE-HQ, DOE Richland (RL) and DOE Savannah River (SR) and contractors Westinghouse Savannah River and Fluor Hanford for the deactivation planning at F Canyon, FB Line and associated facilities at SR. A resource loaded schedule for development of the Work Unit Library, field walk-downs and an estimate for approximately forty facilities at Idaho National Engineering and Environmental Laboratory (INEEL) were also prepared. In addition, survey reports on five pipeline facilities at the Oak Ridge, Tennessee site were completed along with the data consolidation in support of upcoming engineering study per Kaiser-Hill's request. The data from the study will be used to compare the Rocky Flats Environmental Technology site (RFETS) needs with the Centralized Automated Modular Mobile (CAMM) solutions.

The 324 B Cell cleanout effort continues to experience delays as a result of systems and equipment failures. The project remains behind schedule in supporting TPA milestone, M-89-02, Complete Removal of 324 Building Radiochemical Engineering Cells (REC) B Cell Mixed Waste (MW) and Equipment, due November 30,2000 . Extensive effort by the facility is focused on crane repairs. 


\section{Environmental Management Performance Report - December 909 \\ Section D: 2 - River Corridor}

One of two crane repairs was completed. Parallel path opportunities and alternate work is being defined and pursued. In addition, a recovery plan and schedule have been developed and will be documented in HNF-IP-1289, 324/327 Buildings Stabilization/Deactivation Project Management Plan (PMP), Rev. 3, which will be completed in early January. Implementation of the revised PMP will occur upon approval of the baseline change request (BCR) FSP-2000-013 expected in late January or early February.

Progress has been made in selecting a vendor to provide a robotic arm that will be used in performance of deactivation work in a high radiation environment. Specifically, the robotic arm will be used to complete B Cell characterization work in FY 2001. The Accelerated Site Technology Deployment (ASTD) B Cell robotics contract award is expected in February.

Progress on the acceleration of deactivation at the 327 Facility includes the transfer of eight additional specimen containers from dry storage. To date twenty-nine specimen containers out of 272 planned have been transferred. Consolidation of approximately seventy-five grams of fissile samples from Hot Cells A through I into shielded drums for disposal was also completed. There are approximately 432 grams of fissile samples that require disposition. Other progress includes packaging 26 legacy waste buckets into shielded drums, completing the packaging of 13.9 cubic meters $\left(\mathrm{m}^{3}\right)$ of bulk waste into boxes including the Non Destructive Analysis (NDA) and completion of the NDA for $12.4 \mathrm{~m}^{3}$ of bulk waste packaged in FY 1999.

Fiscal-year-to-date milestone performance (EA, DOE-HQ, and RL) shows that one of three milestones ( 33 percent) was completed on or ahead of schedule and 2 milestones ( 67 percent) are overdue. The Milestone Achievement details, found following cost and schedule variance analysis, provide further information on all milestone types.

\section{ACCOMPLISHMENTS}

- Completed transfer of eight additional specimen containers from the 327 Facility dry storage; 29 transfers out of 272 planned completed to date.

- Completed consolidation of $\sim 75$ grams of fissile samples from 327 Facility Hot Cells A through I into shielded drums for disposal; 432 grams in inventory planned for disposition in FY 2000.

- Completed packaging of 26 legacy waste into shielded drums at the 327 Facility.

- Completed packaging $13.9 \mathrm{~m}^{3}$ bulk waste from 327 Facility into waste boxes including NDA.

- Completed NDA for $12.4 \mathrm{~m}^{3}$ bulk waste from 327 Facility packaged in FY 1999.

- Issued the Uranium Disposition Environmental Analysis for public comment.

- Completed white paper on carbon steel pipe packaging system for $0.95 \& 1.25$ enriched fuel.

- Approved the 231-Z Safety Analysis \& Documentation for characterization. 


\section{Cost Performance (\$M):}

\begin{tabular}{|l|c|c|c|}
\hline & BCWP & ACWP & VARIANCE \\
\hline River Corridor Project & $\$ 11.4$ & $\$ 11.3$ & $+\$ 0.1$ \\
\hline
\end{tabular}

The $\$ 0.1$ million ( 0.9 percent) favorable cost variance is within the established threshold. Further information at the PBS level can be found in the following Cost Variance Analysis details.

\section{Schedule Performance ( $\$ M)$ :}

\begin{tabular}{|l|c|c|c|}
\hline & BCWP & BCWS & VARIANCE \\
\hline River Corridor Project & $\$ 11.4$ & $\$ 12.9$ & $-\$ 1.5$ \\
\hline
\end{tabular}

The $\$ 1.5$ million (11.6 percent) unfavorable schedule variance is primarily due to delays with $B$ Cell clean out activities including waste shipments and estimate update activities. Further information at the PBS level can be found in the following Schedule Variance Analysis details.

\section{ISSUES}

Downtime driven by facility systems/equipment failures continues to create delays in the 324 Facility project schedules. The ongoing crane and facility system failures have placed the project significantly behind schedule.

Strategy/Status: Extensive effort is being focused on crane repairs and their availability. In parallel opportunities to optimize the project sequencing, alternate work arounds are being defined and pursued. Recovery of schedule is expected through the implementation of the updated Project Management Plan (PMP), shift work, and an accelerated shipping schedule (all of these activities will be a part of the plan.

The 324 Building Fire Hazards Analysis (FHA) revision supporting the 324 Building Safety Analysis Report (SAR) update resulted in lower combustible load limits. There is a potential adverse cost impact to work progress at the 324 Building.

Strategy/Status: An implementation plan that allows work to continue and maintain allowable combustible load limits has been developed. Alternative fire suppression capabilities to allow increase in combustible load limits are also being evaluated.

Waste Sampling and Characterization Facility (WSCF) metals analysis deviated from EPA Method 200.8. This resulted in being in a non-compliance state with the National Pollutant Discharge Elimination System Permit.

Strategy/Status: Analysis of archived samples was repeated with no bias. No further actions are required. This is the last month this issue will be reported. 
Environmental Management Performance Repont - Decest $190 \%$

Section D: 2-River Corridor

RIVER CORRIDOR

WBS 1.4.1, 1.4.4, 1.4.6, 1.4.8, 1.4.10, 1.4.11

FY 2000 COST/SCHEDULE PERFORMANCE - ALL FUND TYPES

Cumulative to Date Status
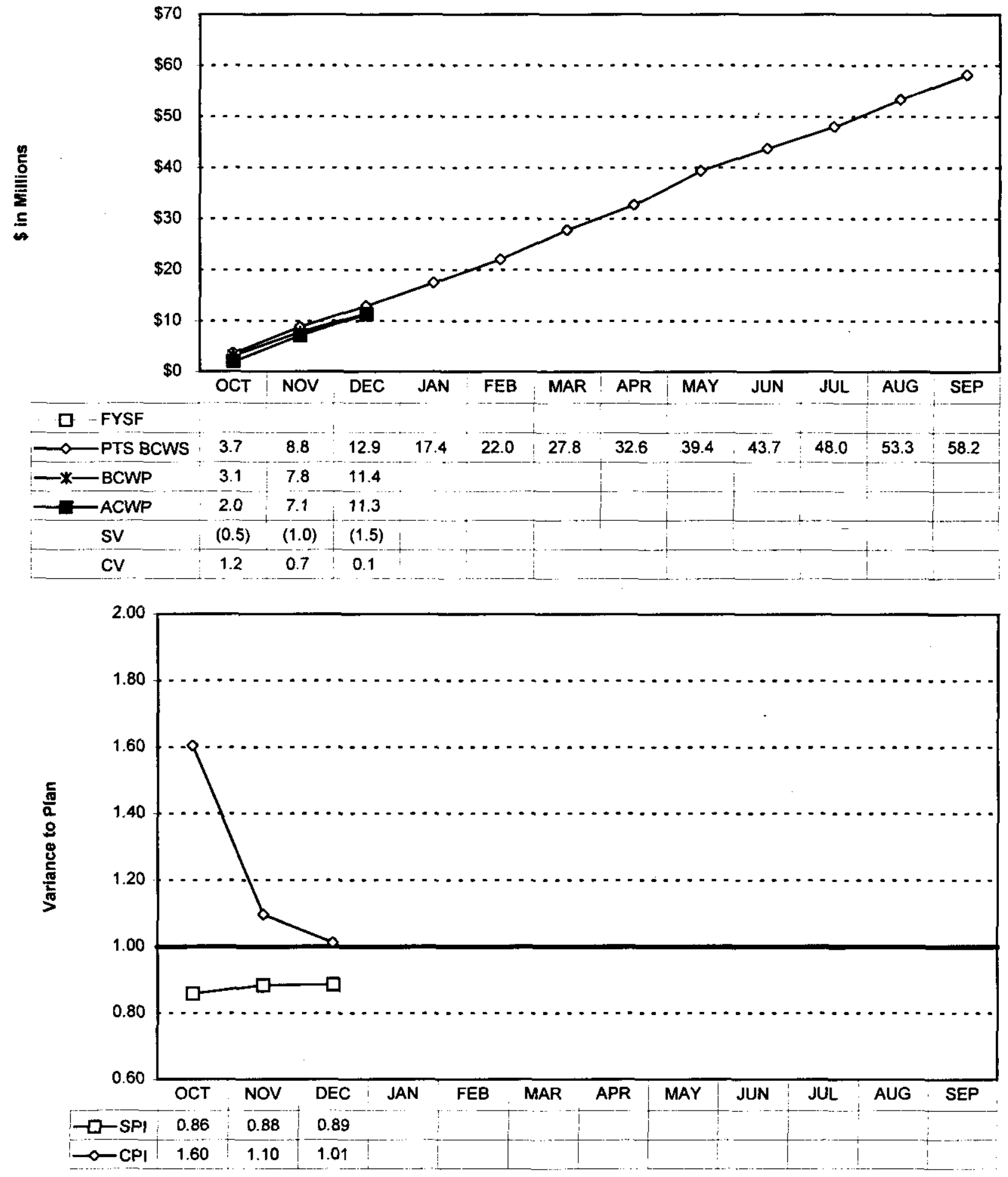


\section{River CORRIDOR \\ WBS 1.4.1, 1.4.4, 1.4.6, 1.4.8, 1.4.10, 1.4.11}

\begin{tabular}{|c|c|c|c|c|c|c|c|c|c|}
\hline & & & & & & & & \multirow[b]{2}{*}{ AUTH } & \multirow[b]{2}{*}{ PTS } \\
\hline & & & \multicolumn{5}{|c|}{ FYTD } & & \\
\hline & & & BCWS & BCWP & ACWP & sV & cy & BSLN & BCWS \\
\hline 1.4.1.1 & B-Plant & Expense & 0.0 & 0.0 & 0.1 & 0.0 & $(0.1)$ & 0.0 & 0.0 \\
\hline TP01 & & CENRTC & 0.0 & 0.0 & 0.0 & 0.0 & 0.0 & 0.0 & 0.0 \\
\hline & & GPP/LI & 0.0 & 0.0 & 0.0 & 0.0 & (0.0) & 0.0 & 0.0 \\
\hline & Subtotal 1.4.1.1 & & 0.0 & 0.0 & 0.1 & 0.0 & $(0.1)$ & 0.0 & 0.0 \\
\hline 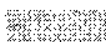 & 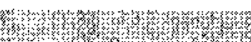 & 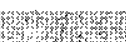 & 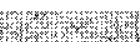 & Whew & & & & & \\
\hline 1.4 .4 .1 & 300 Area/SNM & Expense & 0.6 & 0.6 & $0.7^{3}$ & $(0.0)$ & $(0.0)$ & 27 & 27 \\
\hline TP04 & & CENRTC & 0.0 & 0.0 & 0.0 & 0.0 & 0.0 & 0.0 & 0.0 \\
\hline & & GPP/LI & 0.0 & 0.0 & 0.0 & 0.0 & 0.0 & 0.0 & 0.0 \\
\hline & Subtotal 1.4.4.1 & & 0.6 & 0.6 & 0.7 & $(0.0)$ & $(0.0)$ & 2.7 & 2.7 \\
\hline Why & 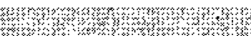 & & & & & & & & \\
\hline 1.4.6.1 & Transition Project & Expense & 4.4 & $4.4^{3.3}$ & 3.2 & $(0.0)$ & 1.2 & 18.8 & 19.4 \\
\hline TP12 & Mgmt & CENRTC & 0.0 & 0.0 & 0.0 & 0.0 & 0.0 & 0.0 & 0.0 \\
\hline & & GPP/LI & 0.0 & 0.0 & 0.0 & 0.0 & 0.0 & 0.0 & 0.0 \\
\hline & Subtotal 1.4.6.1 & & 4.4 & $\overline{4.4}$ & 3.2 & $(\overline{0.0})$ & $\overline{1.2}$ & 18.8 & 19.4 \\
\hline & & & & & & & & & 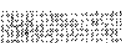 \\
\hline 1.4.8.1 & Accelerated & Expense & 0.6 & 0.7 & 0.5 & 0.1 & 0.2 & 2.5 & 2.5 \\
\hline TP10 & Deactivation & CENRTC & 0.0 & 0.0 & 0.0 & 0.0 & 0.0 & 0.0 & 0.0 \\
\hline & & GPP/LI & 0.0 & 0.0 & 0.0 & 0.0 & 0.0 & 0.0 & 0.0 \\
\hline & Subtotal 1.4.8.1 & & 0.6 & 0.7 & 0.5 & 0.1 & 0.2 & 2.5 & 2.5 \\
\hline 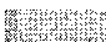 & & W & 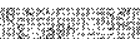 & & & & & AF & 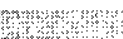 \\
\hline 1.4.10.1 & $324 / 327$ Facility & Expense & 7.1 & 5.6 & 6.8 & $(1.5)^{2}$ & $(1.2)$ & 32.4 & 32.9 \\
\hline TP08 & Transition & CENRTC & 0.0 & 0.0 & 0.0 & 0.0 & 0.0 & 0.0 & 0.0 \\
\hline & & GPP/LI & 0.0 & 0.0 & 0.0 & 0.0 & 0.0 & 0.0 & 0.0 \\
\hline & Subtotal 1.4.10.1 & & 7.1 & 5.6 & 6.8 & (1.5) & $(1.2)$ & 32.4 & 32.9 \\
\hline 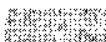 & 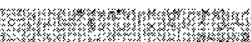 & 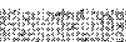 & & 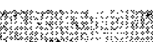 & & 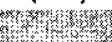 & & & \\
\hline 1.4.11.1 & HSFP 300 Area & Expense & 0.2 & 0.1 & 0.1 & $(0.0)$ & 0.0 & 0.8 & 0.8 \\
\hline TP14 & Revitalization & CENRTC & 0.0 & 0.0 & 0.0 & 0.0 & 0.0 & 0.0 & 0.0 \\
\hline & & GPP/LI & 0.0 & 0.0 & 0.0 & 0.0 & 0.0 & 0.0 & 0.0 \\
\hline & Subtotal 1.4.11.1 & & 0.2 & 0.1 & 0.1 & $(0.0)$ & 0.0 & $\overline{0.8}$ & 0.8 \\
\hline & 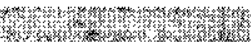 & & & & & & & & \\
\hline RIVER CC & RIDOR & Expense & 12.9 & 11.4 & $\$ 1.3$ & (1.5) & 0.2 & 57.2 & 58.2 \\
\hline TOTAL & & CENRTC & 0.0 & 0.0 & 0.0 & $0.0^{\circ}$ & 0.0 & 0.0 & 0.0 \\
\hline & & GPP/LI & 0.0 & 0.0 & 0.0 & 0.0 & $(0.0)$ & 0.0 & 0.0 \\
\hline & River Corridor Tota & & 12.9 & 11.4 & $\sqrt{11.3}$ & $(1.5)$ & 0.1 & 57.2 & 58.2 \\
\hline
\end{tabular}




\section{Cost VARIANCE ANAlysis: $(+\$ 0.1)$}

\section{WBS/PBS $\quad \underline{\text { Title }}$}

\subsection{1/TP01 B Plant}

Description and Cause: The unfavorable cost variance is primarily due to unplanned costs associated with the ventilation filter change outs and ductwork repairs.

Impact: Deprives other projects of funding for current year priorities including accelerated deactivation activities.

Corrective Action: Work scope is being performed via an approved Advanced Work Authorization (AWA) while BCR FSP-00-008, which funds the B Plant action items is in process.

\subsection{4/TP04 300 Area / Special Nuclear Materials}

Description and Cause: The unfavorable cost variance is primarily due to higher than planned costs related to the Resource Conservation and Recovery Act of 1976 (RCRA) Waste Acid Treatment System (WATS) activities.

Impact: The impact is currently being evaluated.

Corrective Action: A detailed spend forecast is being developed to determine corrective action plan.

\subsubsection{0/TP08 324/327 Building Deactivation}

Description and Cause: The unfavorable cost variance is primarily due to carryover work scope being performed via an AWA, higher than planned B Cell crane repairs, and performing unfunded accelerated 327 Building deactivation work scope also via AWA. Impact: None. Spending against AWAs is being closely monitored.

Corrective Action: Costs of work being performed via AWA will be measured against baseline performance once the applicable baseline change requests are approved. This is particularly applicable to the effort associated with the 327 accelerated deactivation work scope.

\subsection{8/TP10 Accelerated Deactivation}

Description and Cause: The favorable cost variance is primarily due to a $\mathrm{P} 3^{\mathrm{TM}}$ schedule activity status error resulting in overstated BCWP. The true cost variance is a favorable $\$ 80 \mathrm{~K}$ which is primarily the result of lower than planned labor support to $231-\mathrm{Z}$.

Impact: No impact.

Corrective Action: P3 will be corrected in January to reflect the correct BCWP.

\subsection{6/TP12 Transition Project Management}

Description and Cause: The favorable cost variance is primarily due to the PHMC restructuring which has mapped personnel to other sub-projects, resulting in underruns in labor and contractor support. Other sub-projects are experiencing unfavorable cost variances due to the influx of unplanned personnel from PBS TP 12.

Impact: Not determined. Underruns have been utilized to fund other high priority project and FY 1999 carryover work scope. 


\section{COST VARIANCE ANALYsIS: (+\$0.1)}

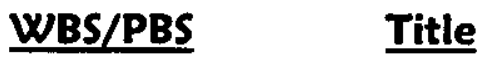

Corrective Action: Re-planning of this account is underway to reflect the new structure, including the transfer of funds to other PHMC sub-projects where former Facility Stabilization personnel have been mapped.

\subsubsection{1/TP14 HSFP 300 Area Revitalization}

Description and Cause: The favorable cost variance is primarily due to less than planned costs in Min Safe surveillance and corrective maintenance activities.

Impact: None.

Corrective Action: Funds made available via underruns will be utilized toward achievement of accelerated deactivation activities.

\section{SCHEDULE VARIANCE ANALYSIS: (-\$1.5)}

\section{WBS/PBS $\quad \underline{T i t l e}$}

\subsubsection{0/TP08 324/327 Building Deactivation}

Description and Cause: The unfavorable schedule variance includes limited progress in the B Cell clean out or waste shipments due to non availability of cell support systems. Additionally, B Cell carryover work scope is being performed via an AWA, which is not reflected in the baseline. Also included in the variance is the PUREX Tunnels work scope, which is not being performed, as this activity is no longer required.

Impact: The continued behind schedule condition jeopardizes achievement of schedule recovery. Corrective Action: Maximum effort is being expended to repair cranes and other cell support systems. The PMP revision, which should be completed in early January, includes a re-sequence of critical path activities that will provide recovery of TPA milestone schedule.

\subsection{8/TP10 Accelerated Deactivation}

Description and Cause: The favorable schedule variance is due to a P3 status error resulting in overstated BCWP. The true schedule variance is an unfavorable $\$ 24 \mathrm{~K}$, which is within the established threshold.

Impact: None

Corrective Action: P3 will be corrected in January to reflect the correct BCWP.

\subsubsection{1/TP14 HSFP 300 Area Revitalization}

Description and Cause: The unfavorable schedule variance is due to delays in performing the baseline estimate update activities. Changes in organization associated with the PHMC restructuring have caused the delay as a result of personnel performing other planned work either within sub-project or other areas.

Impact: Will not complete the estimate update in first quarter as planned.

Corrective Action: Continue activities and provide notifications that estimate update will be completed in second quarter.

All other PBS variances are within established thresholds. 


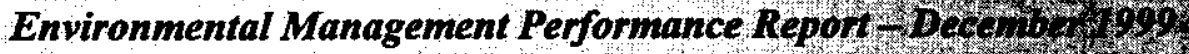
Section D: 2 - River Corridor

River Corridor

MILESTONE ACHIEVEMENT

\begin{tabular}{|c|c|c|c|c|c|c|c|c|}
\hline \multirow[b]{2}{*}{ MILESTONE TYPE } & \multicolumn{4}{|c|}{ FISCAL YEAR-TO-DATE } & \multicolumn{3}{|c|}{ REMAINING SCHEDULED } & \multirow[b]{2}{*}{$\begin{array}{l}\text { TOTAL } \\
\text { FY } 2000\end{array}$} \\
\hline & $\begin{array}{c}\text { Completed } \\
\text { Early }\end{array}$ & $\begin{array}{c}\text { Completed } \\
\text { On } \\
\text { Schedule }\end{array}$ & $\begin{array}{c}\text { Completed } \\
\text { Late }\end{array}$ & Overdue & $\begin{array}{c}\text { Forecast } \\
\text { Early }\end{array}$ & $\begin{array}{c}\text { Forecast } \\
\text { On } \\
\text { Schedule }\end{array}$ & $\begin{array}{c}\text { Forecast } \\
\text { Late }\end{array}$ & \\
\hline Enforceable Agreement & 1 & 0 & 0 & 0 & 0 & 0 & 0 & 1 \\
\hline DOE-HQ & 0 & $\overline{0}$ & 0 & $\overline{0}$ & 0 & 0 & 0 & 0 \\
\hline $\mathrm{FO}$ & 0 & 0 & 0 & 0 & 0 & 0 & 요 & 0 \\
\hline RL & $\overline{0}$ & $\underline{0}$ & 0 & 2 & 0 & 1 & 7 & 10 \\
\hline Total Project & 1 & 0 & 0 & 2 & 0 & 1 & 7 & 11 \\
\hline
\end{tabular}

\section{Total Project}
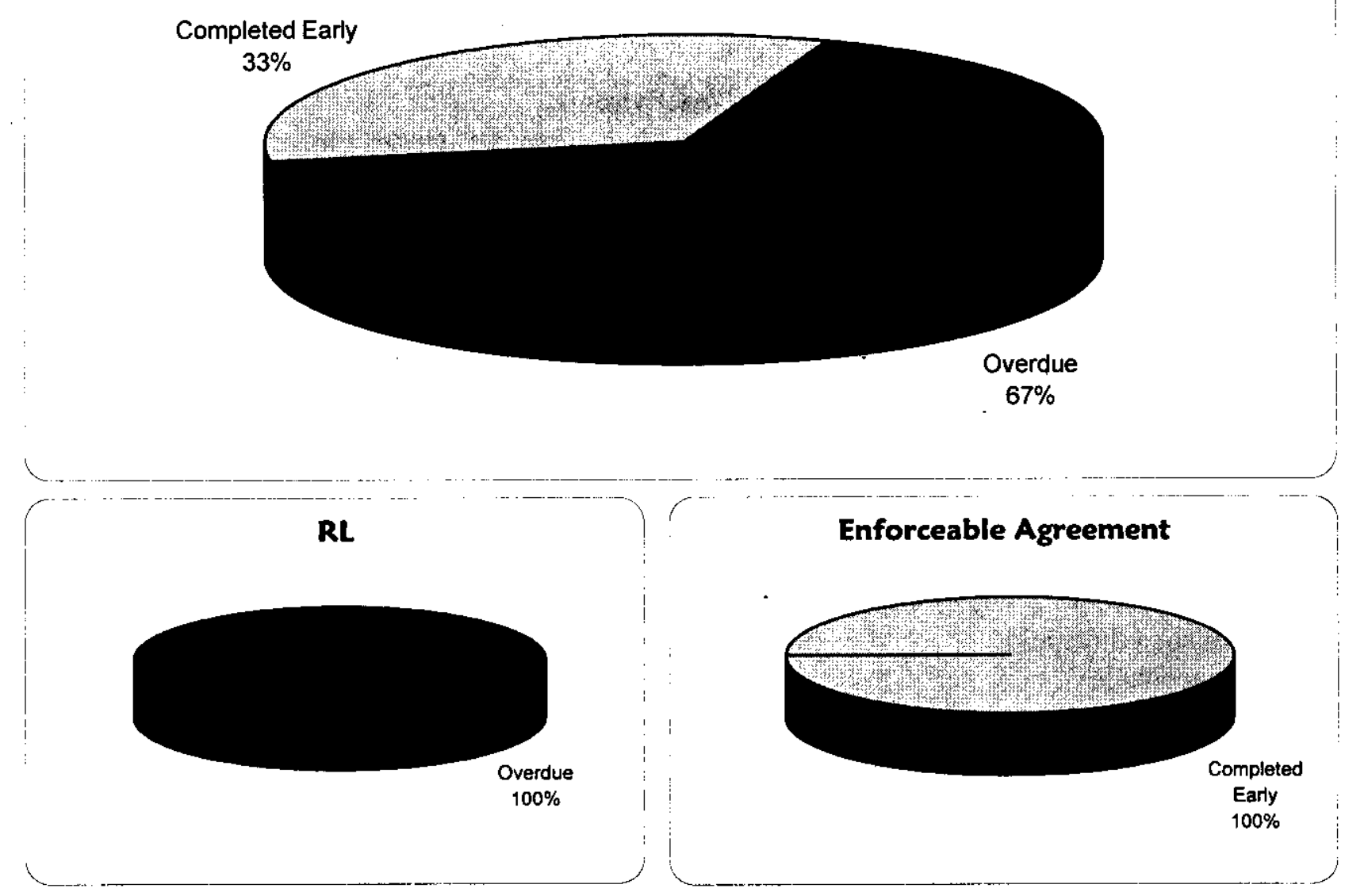


\section{MILESTONE EXCEPTION REPORT}

\section{Number/WBS Level Milestone Title Date Date}

Baseline Forecast

\section{OVERDUe - 2}

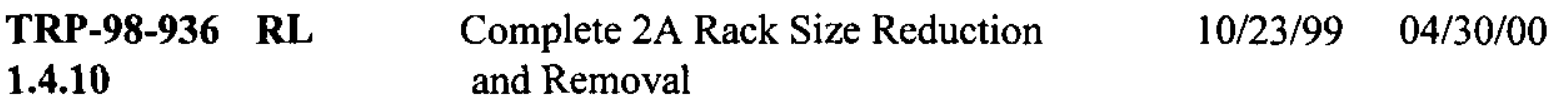

Cause: Building systems, including facility cranes, are not operating in a manner that allows progress on project schedules.

Impact: Currently six months behind schedule to support TPA milestone M-89-02 due November 2000.

Corrective Action: Increased emphasis has been placed on improving systems availability. Additionally, the revised PMP will re-sequence critical path activities that will provide recovery to the schedule. Implementation of the revised PMP will occur upon approval of

BCR FSP-00-013.

\section{$\begin{array}{llll}\text { TRP-99-933 RL Complete Containerization of Dispersible } & 11 / 06 / 99 & 04 / 30 / 00\end{array}$ 1.4.10 under 2A Rack}

Cause: Building systems, including facility cranes, are not operating in a manner that allows progress on project schedules.

Impact: Currently six months behind schedule to support TPA milestone M-89-02 due November 2000 .

Corrective Action: Increased emphasis has been placed on improving systems availability. Additionally, the revised PMP will re-sequence critical path activities which includes revising the completion date of this milestone and mitigating schedule impact to M-89-02.

Implementation of the revised PMP will occur upon approval of BCR FSP-00-013.

\section{FORECAST LATE - 7}

TRP-99-907 RL Complete 1A Rack 382-B Cask Shipments 01/01/00 05/30/00

\subsubsection{0}

Cause: Building systems, including facility cranes, are not operating in a manner that allows progress on project schedules.

Impact: Currently four months behind schedule to support TPA milestone M-89-02 due November 2000.

Corrective Action: Increased emphasis has been placed on improving systems availability. Additionally, the revised PMP will re-sequence critical path activities which includes revising the completion date of this milestone and mitigating schedule impact to M-89-02.

Implementation of the revised PMP will occur upon approval of BCR FSP-00-013. 


\section{MILESTONE EXCEPTION REPORT}

\section{Number/WBS Level Milestone Title}

TRP-99-910 RL

1.4.10

\section{Baseline Forecast \\ Date Date}

01/11/00 Proposed

Cause: The decreased availability of the facility cranes and delay in grout container characterization activities resulted in work scope delays.

Impact: Minimal impact. Not on TPA M-89-02 critical path.

Corrective Action: This milestone will be deleted upon the completion and implementation of the revised PMP. Implementation of the revised PMP will occur upon approval of BCR FSP-00-013.
TRP-99-945 RL
Complete shipment of one RH-TRU
01/13/00 Proposed
1.4.10
Grout Container
Deletion

Cause: The decreased availability of the facility cranes and delay in grout container characterization activities resulted in work scope delays.

Impact: Minimal/None.

Corrective Action: This milestone will be deleted upon completion and implementation of the revised PMP, which re-sequences B Cell clean out activities. Implementation of the revised PMP will occur upon approval of BCR FSP-00-013

TRP-99-909 RL Complete 2A Rack 382-B Cask Shipments 03/29/00 02/28/01

\subsubsection{0}

Cause: Building systems, including facility cranes, are not operating in a manner that allows progress on project schedules.

Impact: Currently eleven months behind schedule; however, delay does not affect TPA milestone M-89-02, due November 2000.

Corrective Action: Increased emphasis has been placed on improving systems availability. Additionally, the revised PMP will re-sequence critical path activities which includes revising the completion date of this milestone and mitigating schedule impact to M-89-02.

Implementation of the revised PMP will occur upon approval of BCR FSP-00-013.

$\begin{array}{llll}\text { TRP-00-914 RL } & \text { PUREX Tunnels Ready to Receive } & 04 / 20 / 00 & \begin{array}{l}\text { Proposed } \\ \text { Deletion }\end{array} \\ \text { 1.4.10 } & \text { B Cell MW/SCW } & & \end{array}$

Cause: Revision to the Special Case Waste Study, completed in September 1999, determined waste shipments to Central Waste Complex (CWC) was a better option than the Purex tunnels. Impact: No impact. Work no longer planned for tunnel disposition.

Corrective Action: This milestone will be deleted upon completion and implementation of the revised PMP, which re-sequences B Cell clean out activities and eliminates use of PUREX tunnels for storage of special-case waste (SCW). Implementation of the revised PMP will occur upon approval of BCR FSP-00-013. 


\section{MILESTONE EXCEPTION REPORT}

\section{Number/WBS Level Milestone Title}

TRP-00-915 RL

\subsubsection{0}

Complete the 324 LWHS Design \&

Construction

\section{Baseline Forecast Date Date}

$06 / 30 / 00 \quad 09 / 30 / 03$

Cause: Delays in design approval driven by need for additional characterization of the physical, installed transfer systems that will interface with LWHS.

Impact: Currently thirty-nine months behind schedule; however delay does not affect TPA milestone M-89-02 due November 2000.

Corrective Action: This activity will be performed in a different sequence than currently planned in support of final deactivation. The milestone date will be revised upon implementation of the revised PMP, which will occur upon approval of BCR FSP-00-013.

TRP-00-931 RL Complete SCW Shipments to Storage $\quad 09 / 29 / 00 \quad 11 / 30 / 00$

\subsubsection{0}

Cause: Building systems, including facility cranes, are not operating in a manner that allows progress on project schedules. Cranes are required to package, characterize and move waste containers.

Impact: Currently two months behind schedule to support TPA milestone M-89-02 due November 2000.

Corrective Action: Increased emphasis has been placed on improving systems availability. The milestone date will be revised upon implementation of the revised PMP, which will occur upon approval of BCR FSP-00-013.

\section{FY 1999 OVERDUE - 1}
TRP-99-937 RL
Remove, Package \& Ship Excess
09/30/99
Proposed
1.4.10
Equipment from B Cell
Deletion

Cause: The work scope related to this milestone was included in the 324 B Cell Cleanout work scope reconfiguration per approved BCR FSP-99-017. The milestone should have been deleted with the approval of FSP-99-017 but was overlooked.

Impact: None. This milestone is obsolete.

Corrective Action: This milestone will be deleted upon implementation of the revised PMP, which will occur upon approval of BCR FSP-00-013. 


\section{Building Deactivation}

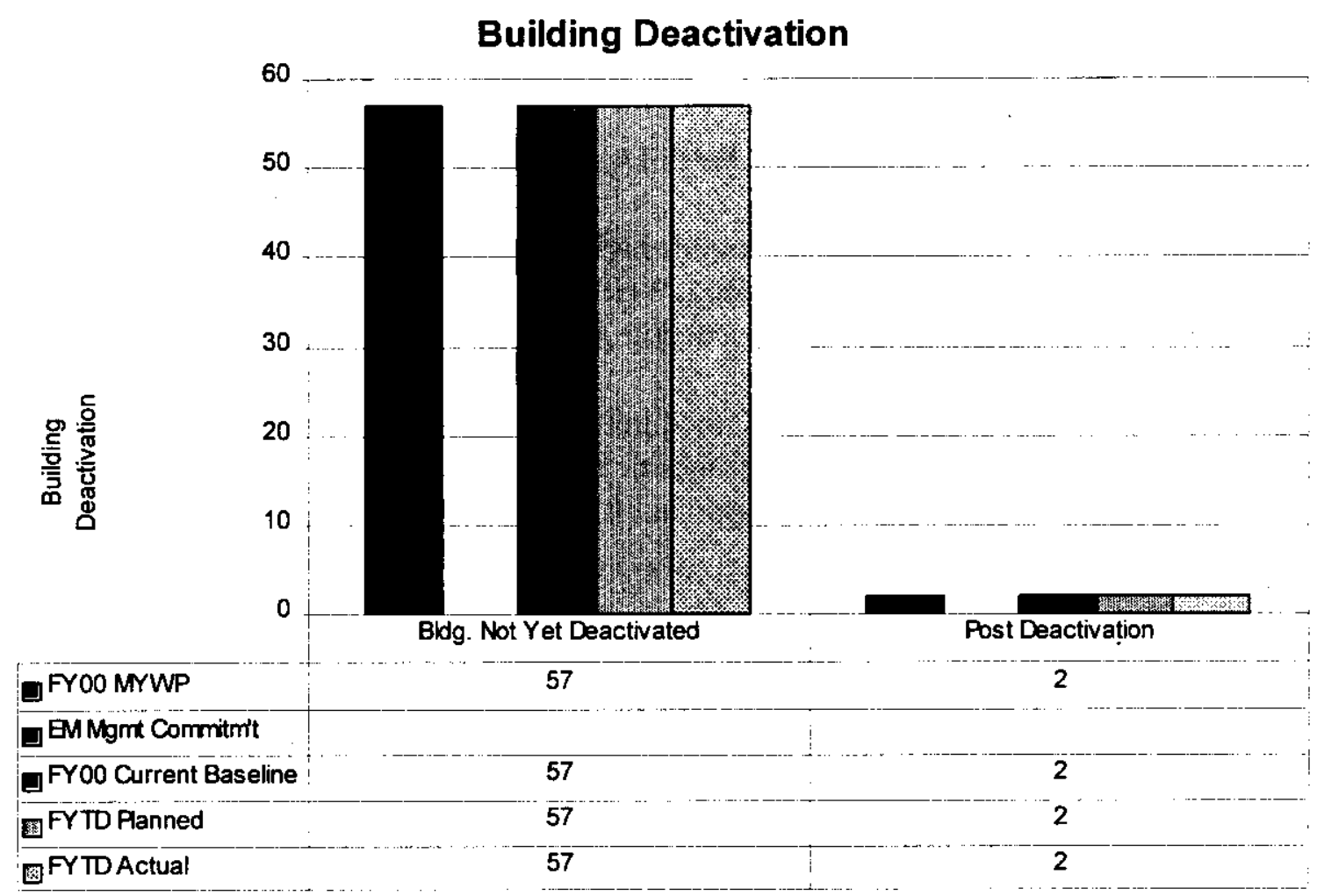

Buildings Not Yet Deactivated: The current baseline does not fund building deactivation in FY 2000.

Post Deactivation: These two buildings, deactivated in FY 1996, are in post-deactivation surveillance until formal turnover to the ERC, when the 300 Area Fuel Supply Shutdown project is completed in FY 2001. 

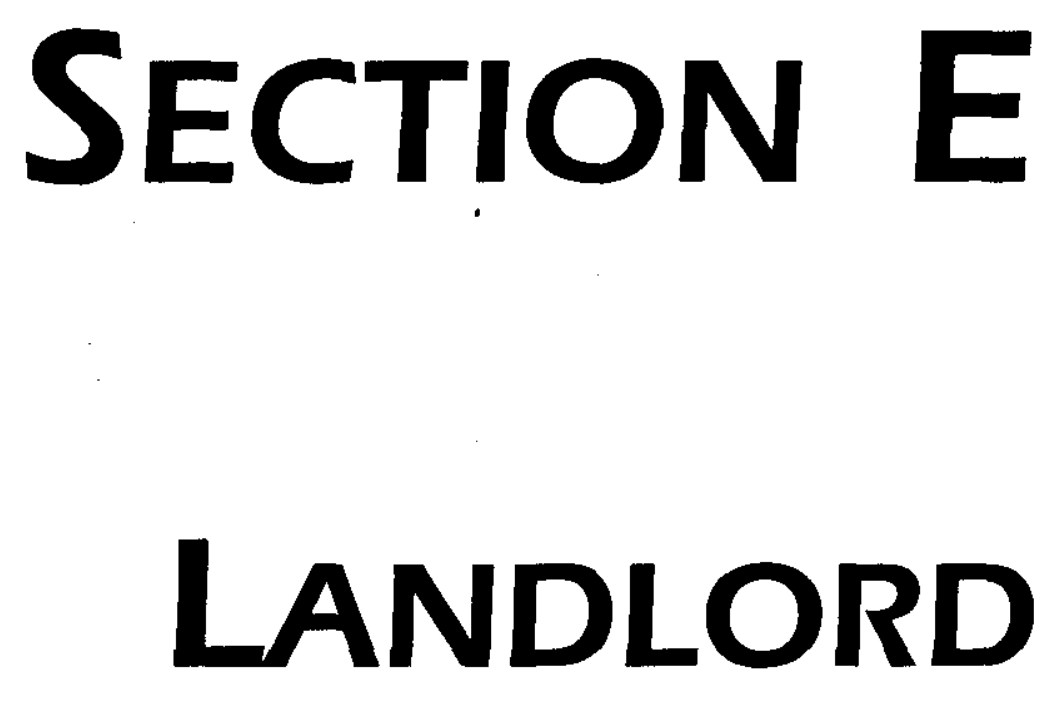

\title{
AS OF DECEMBER 31, 1999
}

PROJECT MANAGERS

\author{
S. H. Wisness, RL \\ Phone: (509) 373-9337 \\ D. S. Kelly, FH \\ Phone: (509) 376-7334
}




\section{SUMMARY}

The Landlord mission area consists of the Landlord Project, WBS 1.5.1, Project Baseline Summary (PBS) RL-TP13.

The Landlord Project bridge change request, accompanying the FY 2000 Multi Year Work Plan (MYWP) update, was disapproved by DOE-RL. The proposed life-cycle change increased the baseline by approximately $51 \%$ and exceeds the threshold that RL can approve; it must go to DOE-HQ for approval. The proposed change incorporates necessary infrastructure system upgrades, capital equipment replacements, 338 non-contaminated facilities assigned to Landlord in the out years, and new workscope for the Integrated Site Vegetation and Animal Control (ISVAC) Project. The path forward is to submit three separate Baseline Change Requests (BCRs) as follows: 1) FY 2000 through 2002 time frame, 2) FY 2003 through 2046 (Project end-of-life), and 3) ISVAC which is new workscope directed by DOE-RL to be added to the FY 2001 and out years baseline. A baseline change request for FY 2000 to FY 2002 was approved by the change control board and was forwarded to RL for final approval. This BCR will provide performance data in the financial system.

\section{ACCOMPLISHMENTS}

No major RL milestones were planned or completed through December, 1999. The Milestone Achievement and Milestone Exception Report have not been included in this section because there are no milestones for the fiscal year.

\section{Cost Performance $(\$ M):$}

\begin{tabular}{|l|c|c|c|}
\hline & BCWP & ACWP & VARIANCE \\
\hline Landlord & $\$ 0.0$ & $\$ 1.5$ & $-\$ 1.5$ \\
\hline
\end{tabular}

FY 2000 baseline information is not loaded in HANDI; therefore, project performance cannot be demonstrated in the performance module.

Project L-291, Sanitary Water \& Sewer to the Patrol Training Academy, completed final project closeout. This was a carryover project that provides a sanitary water and sewer line from HAMMER that connects the Patrol Training Academy to the City of Richland water and sewer systems. 


\section{SChedule Performance ( $\$ M)$ :}

\begin{tabular}{|l|c|c|c|}
\hline & BCWP & BCWS & VARIANCE \\
\hline Landlord & $\$ 0.0$ & $\$ 0.0$ & $\$ 0.0$ \\
\hline
\end{tabular}

FY 2000 baseline information is not loaded in HANDI; therefore, project performance cannot be demonstrated in the performance module. The Cost Variance Analysis and Schedule Variance Analysis will be included as soon as the baseline information is available in the performance module.

\section{ISSUES}

Landlord Project FY 2000 Bridge BCR submitted with the Multi-Year Work Plan in August 1999 was disapproved. Life-cycle baseline increase of 51\% exceeds DOE-RL approval thresholds. After RL reviewed the Bridge BCR changes it was decided to develop and submit multiple BCRs.

Strategy/Status: Three separate BCRs are being prepared as follows: 1) FY 2000 through 2002 time frame, 2) FY 2003 through 2046 (Project end-of-life), and 3) ISVAC which is new workscope directed by RL to be added to the FY 2001 and out years baseline. FY 2000 baseline information can not be loaded in HANDI without approval of the first BCR, which covers FY 2000 through 2002. Therefore, project performance cannot be demonstrated in the performance module. 


\section{Building Deactivation}

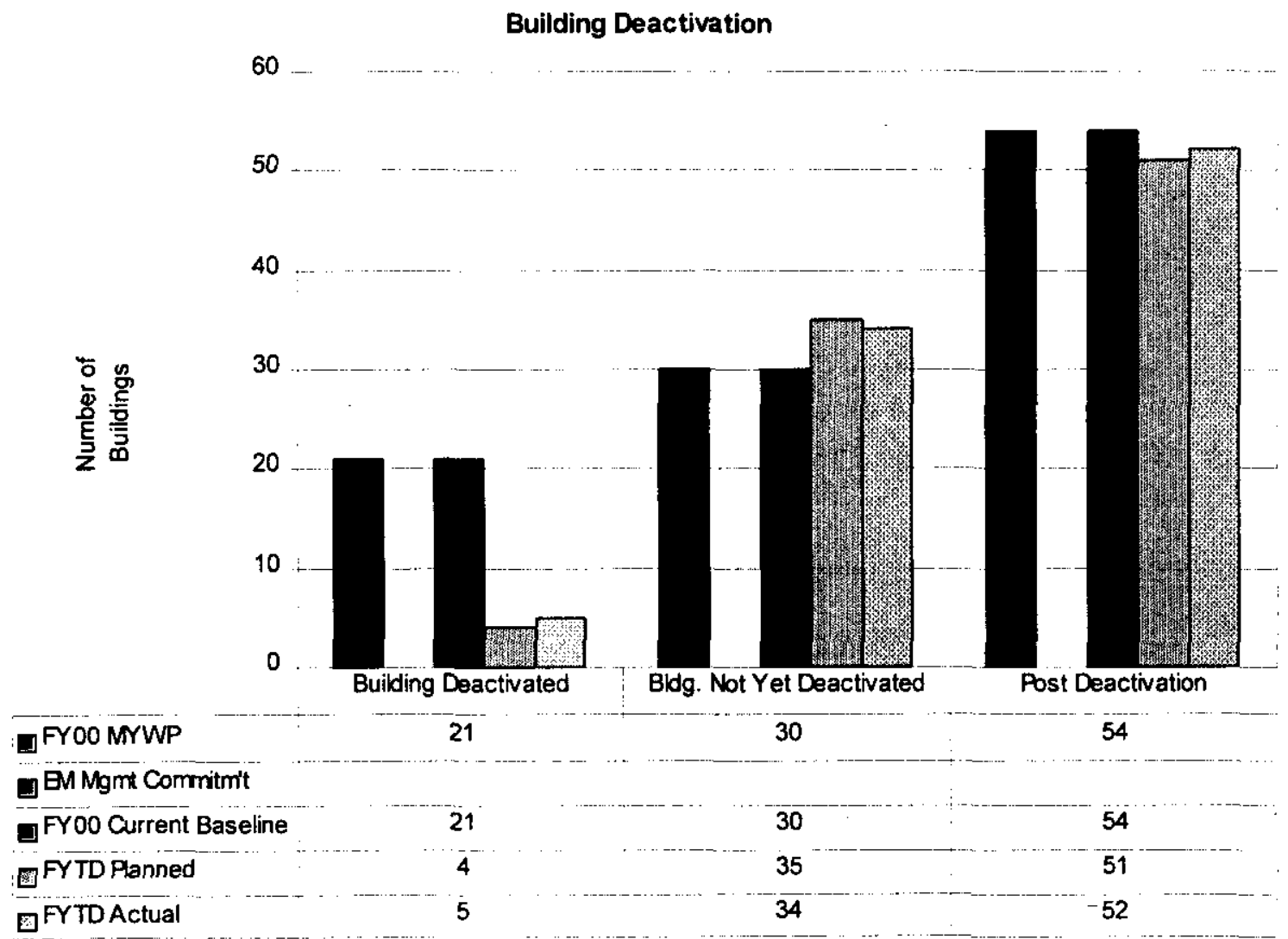

Buildings Deactivated: Performance is within $+/-10 \%$, therefore no variance explanation is provided.

Buildings Not Yet Deactivated: Performance is within $+/-10 \%$, therefore no variance explanation is provided.

Post Deactivation Monitoring: Performance is within $+/-10 \%$, therefore no variance explanation is provided. 


\section{FaCility Decommissioning - Cleanups}

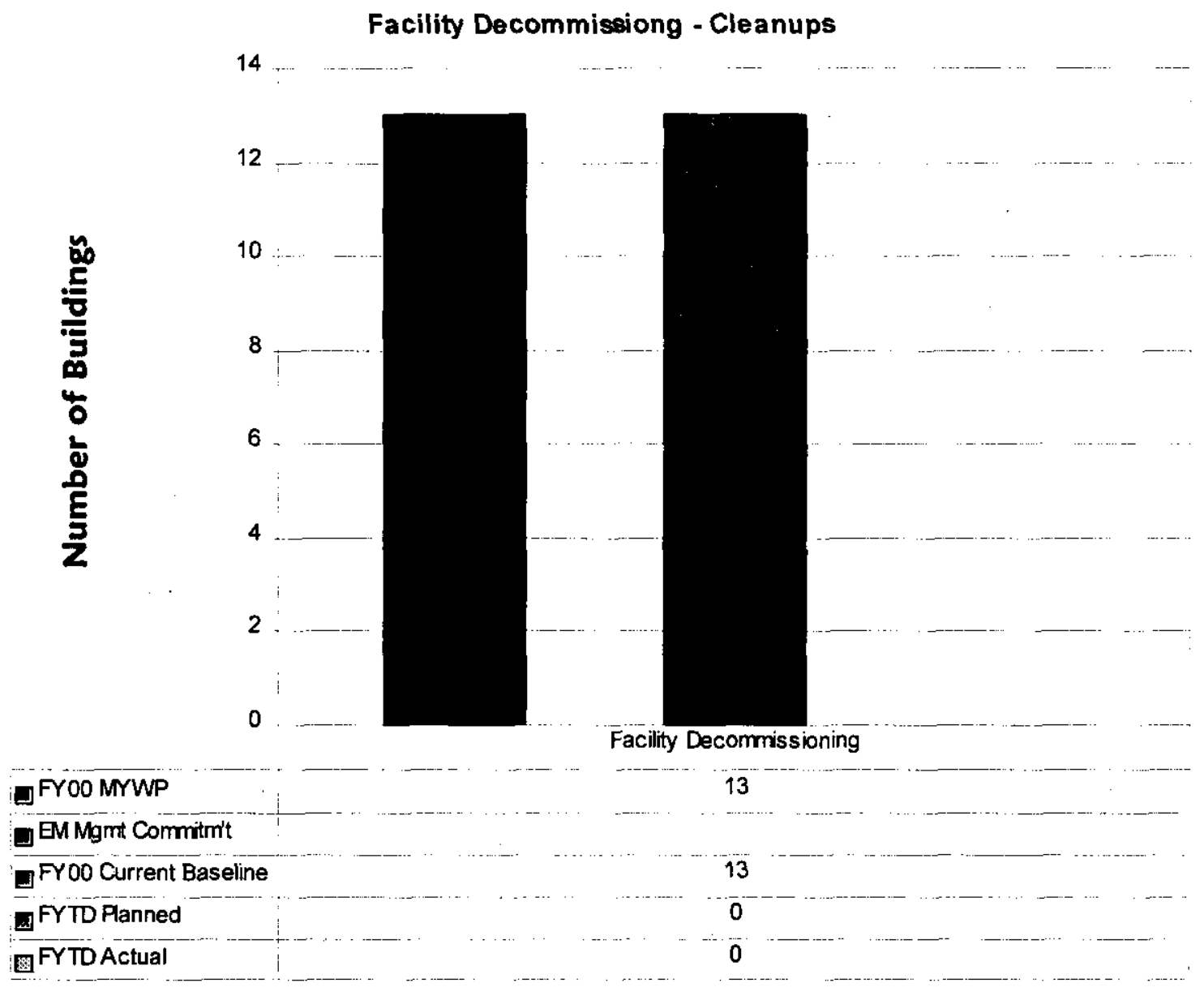

Facility Decommissioning: None planned for this period. 

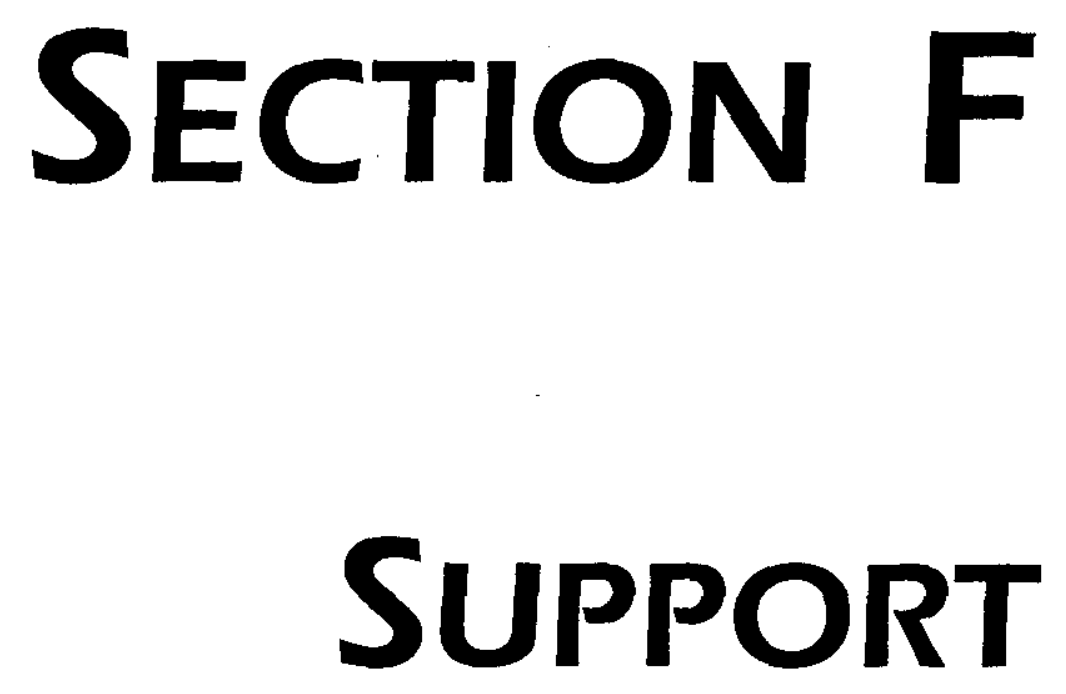

\section{AS OF DECEMBER 31, 1999}

PROJECT MANAGERS

SP\&I W. W. Ballard, RL G. J. McCleary, FH

SSE W. W. Ballard, RL

$$
\text { M. L. Grygiel, FH }
$$

ECP S. H. Wisness, RL

$$
\text { J. W. Hales, FH }
$$

PSRP S. H. Wisness, RL

R. L. Dirkes, PNNL
(509) 376-6657

(509) 372-8385

(509) 376-6657

(509) 372-2983

(509) 373-9337

(509) 376-4069

(509) 373-9337

(509) 376-8177 


\section{SUMMARY}

The project consists of Site Support, Project Baseline Summary (PBS) OT04 and Mission Support, PBS OT01. Site support is RL directed support and Mission Support consists of four sub-projects:

- $\quad$ Planning and Integration (Work Breakdown Structure (WBS 1.8.2.1)

- $\quad$ Systems Engineering (WBS 1.8.2.2)

- $\quad$ Environmental Compliance (WBS 1.8.2.3)

The Environmental Compliance Program is composed of two elements. These two elements were stand-alone programs known as the Hanford Environmental Management Program (HEMP) and the Effluent and Environmental Monitoring Program (EEM) prior to FY99. Although there is a single program, these elements retain their identity on the Integrated Priority List as two separate Units of Analysis. Public Safety and Resource Protection (WBS 1.8.2.4)

In addition, Richland Directed Activities, PBS OT04, is included in this section. It consists of general site requirements such as :

- $\quad$ Resource Conservation and Recovery Act [RCRA] Mixed Waste Fee (management fee)

- Department of Health (DOH) Oversight (air monitoring)

- Downwinder Litigation

- $\quad$ Permits/site support [State of Washington (air emissions program)]

- $\quad$ Emergency Preparedness Grants

- State of Oregon Hanford Oversight

- $\quad$ Payment in Lieu of Taxes

- Hanford Advisory Board/Miscellaneous Grants (Hanford Openness Panel)

- Uranium Mass Balance Project (Paducah)

- National Security Analysis (formerly declassification of documents)

- As well as other minor financial assistances and contracts.

Fiscal-year-to-date milestone performance (EA, DOE-HQ, and RL) shows that 7 of 8 milestones ( 88 percent) were completed on or ahead of schedule and one milestone (12 percent) was completed late. The Milestone Achievement details, found following cost and schedule variance analysis, provide further information on all milestone types.

Planning and Integration - Preparations for the release of the Site Paths to Closure document to the regulators/public were finalized during December.

For FY 2001 budget formulation, SP\&I continues to support the development of the special submission of the funding requirements associated with Safeguard and Security activities. Phase 2 submission defines the amount of funding that will be transferred from the Environmental Management (EM) Program to the Safeguard and Security Office (SO). FH has identified impacts by Project Baseline Summaries (PBSs) so that the FY 2001 President's Budget Justification material, if directed, could be changed. The transfer in the Budget submission has 
not been implemented; however, indications are that an amended budget will be submitted in February to effect this transfer.

Additional modules within the Integrated Planning, Accountability, and Budgeting System (IPABS) have been released. The Planning and Budgeting Modules join the Project Execution Module (PEM), the Reporting Module, and the Administration Module to complete the system. IPABS is a web-based application that will be used for submittal of all HQ-level planning, budgeting, and performance information. Efforts are underway to adapt local planning and reporting tools to provide the necessary electronic feeds to IPABS.

Support was provided to the updating of the FY 2001 President's Budget justification material based upon the Office of Management and Budget (OMB) passback and DOE-HQ's appeal. SP\&I participated in planning meetings and provided hard copy documents for redlining since the IPABS access and availability at the time was still limited.

The first quarterly report submission to the PEM, due January 21,2000 , will be completed using a manual input to the PEM web-based application. Efforts to modify the computer systems to electronically collect, format, report and provide batch-feed capabilities are currently underway.

The Hanford Site Performance Report (HSPR) is undergoing a major overhaul. The name has changed to the Richland Operations Office Environmental Management Performance Report (EMPR). The name change was necessary due to the split of Hanford into two DOE offices RL and Office of River Project (ORP). The ORP mission is no longer reported in the new EMPR. Further changes include:

- Most of the information formerly contained in the Site Summary section will be reported only twice a year; the remainder of the data has been moved to the Executive Summary.

- The report will no longer focus on Critical Success Factors and Success Indicators, but rather on the RL Critical Outcomes.

- An additional change for the December report involves having FH, BHI and PNNL prepare separate reports on their Environmental Cleanup Mission work. These individual reports are then submitted to $\mathrm{FH}$, which assembles them into one document to complete the new EMPR.

A number of products are being generated by SP\&I in support of the team of contractor personnel assembled to develop alternative approaches or scenarios for determining site work/funding priorities. Specifically, summary schedule, and resource (cost) and milestone data for Hanford's projects through 2016 are being prepared. The intent is to provide RL/Contractor senior management with a tool that would be used to support prioritization of work, assist in annual update of the Site Integrated Priority List, and evaluate impacts of proposed baseline change requests; thereby providing the capability to look at alternative scenarios for site cleanup in a more timely fashion.

Site Systems Engineering (SSE) - Site Systems Engineering and Integration continued to work with Frontline Solutions to develop a modeling capability for "what if" scenarios on the Hanford Site Environmental Management Specification (HSEMS). At completion, 72 major facilities will be modeled; 35 are currently complete. 
SSE is supporting Environmental Services Chemical Management Program in evaluating the capabilities of the recently implemented Indus PassPort ${ }^{\mathrm{TM}}$, commercial-off-the-shelf (COTS) Enterprise Resource Planning (ERP) software module to manage chemical inventory data for the PHMC.

SSE sponsored a one week Value Engineering study to determine ways to integrate the FH Requirements Management activities, the Project Hanford Management System, the FH Standards/Requirements Identification Document (S/RID), and the Hanford Site Technical Baseline.

\section{Environmental Compliance Program (ECP) - Four ECP Milestones were due in} December and all four were completed early.

Spill/Release Reporting:

For the month of December, there were seven (7) non-reportable spills of hazardous and/or petroleum products to the environment; one (1) reportable event with a release to the environment and eight (8) reportable non-compliance events without a release to the environment. The 1st Quarter FY2000, FH Quarterly Spill and Release Report has been completed per the requirements of the FY2000 Technical Workscope, Environmental Compliance Program.

Inspection Support:

- Prepared the 2000 Hanford Permit Inspection Schedule for issue to Ecology.

- $\quad$ Performed pre-Facility Evaluation Board (FEB) assessment of the Low-Level Burial Grounds (LLBG), Central Waste Complex (CWC), T Plant, and 616 water quality program (includes physical walkdowns, Regulatory File and Procedure Reviews, and written General Assessment Evaluations for each facility)

- $\quad$ Supported a internal compliance assessment of Plutonium Finishing Plant (PFP) and issued assessment report

- $\quad$ Supported resolution of FEB assessment findings for Waste Receiving and Processing (WRAP).

- Performed a management assessment on the Hanford Facility [Resource Conservation and Recovery Act of 1976 (RCRA) Permit] Operating Record.

- Coordinated the weeklong Ecology Clean Air Act (CAA) inspection that began on December 9.

RCRA Permit Revision and Implementation:

- Developed, coordinated and supported the preparation of the comment package for Modification E proposed Permit modifications for transmittal to Ecology.

- Developed, coordinated and supported the preparation of the comment package for the proposed modifications to the Hazardous Solid Waste Amendments (HSWA) Portion of the Permit for transmittal to U. S. Environmental Protection Agency (EPA).

- Developed and supported Bechtel Hanford, Incorporated (BHI) and RL with the preparation of the comment package for the transfer of corrective action authority from the EPA to Washington State Department of Ecology (Ecology).

- Coordinated and prepared the Quarterly Class 1 Permit modification for quarter ending 
December 31, 1999 for transmittal to Ecology. Units included in the modification package were Liquid Effluent Retention Facility / Effluent Treatment Facility (LERF/ETF), 242-A Evaporator, 305-B Storage Facility, and the 325 Hazardous Waste Treatment Units (HWTU).

Environmental Center of Expertise (COE) Established:

The Environmental COE was established and convened. The COE purpose is identify and resolve sitewide environmental issues and includes representation from all FH Projects and Service Providers. Two issues have been identified for COE action and are currently being analyzed.

Public Safety and Resource Protection (PSRP) - The PSRP Program Projects were all conducted in accordance with the scope, milestones, and budget defined in the FY 2000 PSRP Program [Mission Support (PBS \#RL-OT01)] Multi-Year Work Plan during December.

\section{ACCOMPLISHMENTS}

SP\&I Planning and Integration completed two deliverables in December: Annual Update of the Workforce Staffing Plan and an update to the EM Liabilities report. The latter report integrated an estimate for long term surveillance and maintenance of the Hanford Site after the EM cleanup mission is completed in FY 2046. The estimate was refined by re-evaluating project requirements and applying those requirements to an estimating model.

In mid December, the FY 2002 Budget Formulation project control kickoff meeting was held. Weekly project control meetings have been initiated to facilitate implementation of updated guidance and resolve issues.

SP\&I also developed an updated P3 ${ }^{\mathrm{TM}}$ software rate library to support re-pricing of the FY 2000 baseline and update of the FY 2001 and FY 2002 budgets. Updates were made to reflect the changes in indirect rates associated with streamlining our indirect budget baselines and incorporating changes brought about by the split-off of the River Protection Program from the Project Hanford Management Contract (PHMC).

The budget rates for FY 2001 and FY 2002 were updated to reflect the proposed movement of specific indirect funded work activities to direct funded accounts. Training sessions were held with project counterparts to orient them regarding the assumptions utilized in developing the rates.

SSE supported the Uranium Disposition activities in preparing and issuing a Program Management Plan. The plan is currently being reviewed for approval.

- The milestone, ECP-00-705, RCRA Reports/Documents/Annual Permit Status ReportOn Internet due on 12/1/99, was completed on schedule.

- The milestone, ECP-00-508, RCRA Section 3016 Report (Hazardous Waste Facility), on $12 / 6 / 99$, was completed one week ahead of schedule.

- The milestone, ECP-00-306, Annual BCAA Asbestos Notification, on 12/31/99, was 


\section{Environmental Management Peformance Repot $-b_{t}+4,4,4$ \\ Section F-Mission Support}

submitted two weeks ahead of schedule.

- $\quad$ The milestone, ECP-00-411, PTRAEU $1^{\text {st }}$ Quarter Assessment Report, due on 12/31/99, was submitted on schedule.

All projects within the Public Safety and Resource Protection Program successfully weathered the transition into the year 2000 without any Y2K problems. Several precautionary activities were conducted in anticipation of potential problems and program activities continued into $\mathrm{CY}$ 2000 seamlessly.

The Hanford Meteorology Station (HMS) switched to a personal computer (pc)-based computer network for gathering and processing all of the data from the Hanford Meteorological Monitoring Network and other data acquisition activities on December 16th. This system consists of five networked personal computers each with a specific data collection and processing function. The transition from the IBM RISC/6000 to the pc-based system was seamless, with no interruption in the data gathering process. There is a significant annual cost savings in the pcbased versus the IBM RISC system. The maintenance contract on the IBM RISC/6000 system has been about $\$ 35 \mathrm{~K}$ annually. This entire pc-network cost less than $\$ 15 \mathrm{~K}$ to buy and set up, and maintenance costs are essentially zero.

\section{Cost Performance (\$M):}

\begin{tabular}{|l|c|c|c|}
\hline & BCWP & ACWP & VARIANCE \\
\hline 1.8 Support & $\$ 9.8$ & $\$ 9.1$ & $+\$ 0.8^{*}$ \\
\hline
\end{tabular}

*Rounding

The $\$ 0.8$ million (7.1 percent) favorable cost variance is due to labor costs less than anticipated. Further information at the PBS level can be found in the following Cost Variance Analysis details.

\section{Schedule Performance (\$M):}

\begin{tabular}{|l|c|c|c|}
\hline & BCWP & BCWS & VARIANCE \\
\hline 1.8 Support & $\$ 9.8$ & $\$ 10.3$ & $-\$ 0.5$ \\
\hline
\end{tabular}

The $\$ 0.5$ million (4.9 percent) unfavorable schedule variance is within acceptable reporting thresholds.

\section{ISSUES}

There are no noteworthy issues at this time. 


\section{MISSION SUPPORT \\ WBS 1.8}

FY 2000 COST/SCHEDULE PERFORMANCE - ALL FUND TYPES

\section{Cumulative to Date Status}
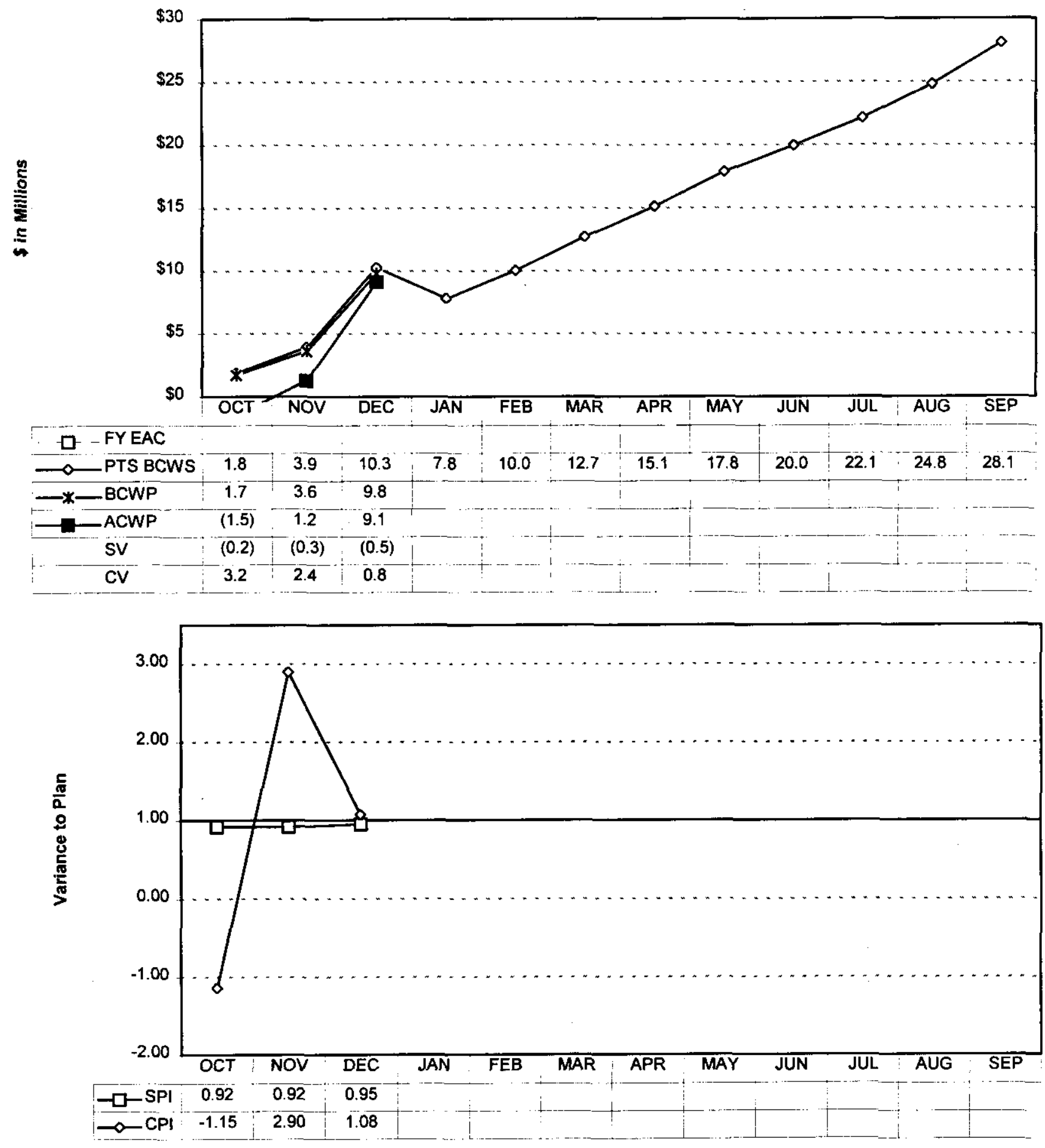


\section{MISSION SUPPORT \\ WBS 1.8}

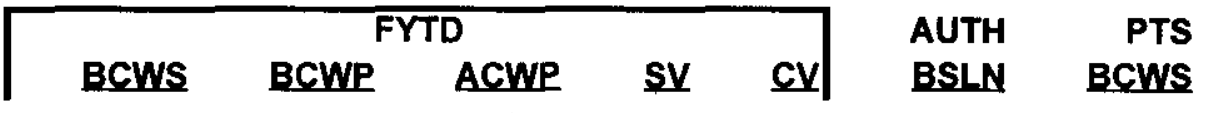

\section{SITE SUPPORT}

\begin{tabular}{|c|c|c|c|c|c|c|c|c|c|}
\hline \multirow{4}{*}{$\begin{array}{l}1.8 .1 \\
\text { ОT04 }\end{array}$} & \multirow{3}{*}{ RL Directed Su } & Expens & 4.8 & 4.8 & 4.8 & 0.0 & $(0.0)$ & 18.0 & 0.0 \\
\hline & & CENRT & 0.0 & 0.0 & 0.0 & 0.0 & 0.0 & 0.0 & 0.0 \\
\hline & & GPP/LI & 0.0 & 0.0 & 0.0 & e.0 & 0.0 & 0.0 & 0.0 \\
\hline & \multicolumn{2}{|c|}{ SITE SUPPORT Total } & 4.8 & 4.8 & 4.8 & 0.0 & $(0.0)$ & 18.0 & 0.0 \\
\hline \multicolumn{10}{|c|}{ MISSION SUPPORT } \\
\hline 1.8 .2 & Mission Spprt/ & Expense & 5.2 & 5.0 & 4.4 & $(0.2)$ & 0.6 & 23.8 & 26.7 \\
\hline \multirow[t]{3}{*}{ OTO1 } & \multirow[t]{2}{*}{ Other MYPs } & CENRTC & 0.0 & 0.0 & 0.0 & 0.0 & 0.0 & 0.0 & 0.0 \\
\hline & & GPP/LI & 0.3 & 0.0 & $(0.1)$ & $(0.3)$ & 0.1 & 18 & 1.4 \\
\hline & \multicolumn{2}{|c|}{ Mission Support Total } & 5.5 & 5.0 & 4.3 & $(0.5)$ & 0.8 & 25.6 & 28.1 \\
\hline & (4) & & (1) & 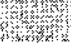 & 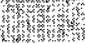 & & & & \\
\hline \multirow[t]{4}{*}{ SUPP } & DRT TOTAL & Expense & 10.0 & 9.8 & 9.2 & $(0.2)$ & 0.6 & 41.8 & 26.7 \\
\hline & & CENRTC & 0.0 & 0.0 & 0.0 & 0.0 & 0.0 & 0.0 & 0.0 \\
\hline & & GPP/LI & 0.3 & 0.0 & (0.1) & $(0.3)$ & $\underline{0.1}$ & 1.8 & 1.4 \\
\hline & Total S & upport & 10.3 & 9.8 & 9.1 & $(0.5)$ & 0.8 & 43.6 & 28.1 \\
\hline
\end{tabular}

\section{COSt VARIANCe ANalysis: $(+\$ 0.8)$}

\section{WBS $\quad \underline{\text { TITLE }}$}

\subsection{2/OT01 Mission Support}

Description and Cause: The $\$ 0.8$ (7.1 percent) favorable cost variance is due to labor costs less than anticipated.

Impact: None.

Corrective Action: None.

\section{SCHEDULE VARIANCE ANALYSIS: $(-\$ 0.5)$}

\section{WBS}

\subsection{2/OT01}

\section{TITLE}

\section{Mission Support}

Description and Cause: The $\$ 0.5$ (4.9 percent) unfavorable schedule variance is within acceptable reporting thresholds.

Impact: None.

Corrective Action: None. 
Environmental Management Performance Report-December 1999 Section F-Mission Support

\section{MISSION SUPPORT - WBS 1.8 MILESTONE ACHIEVEMENT}

\begin{tabular}{|r|r|r|r|r|r|r|r|}
\hline & \multicolumn{4}{|c|}{ FISCAL YEAR-TO-DATE } & \multicolumn{2}{c|}{ REMAINING SCHEDULED } \\
\cline { 2 - 8 } \\
\cline { 2 - 8 }
\end{tabular}

\section{Total Project}

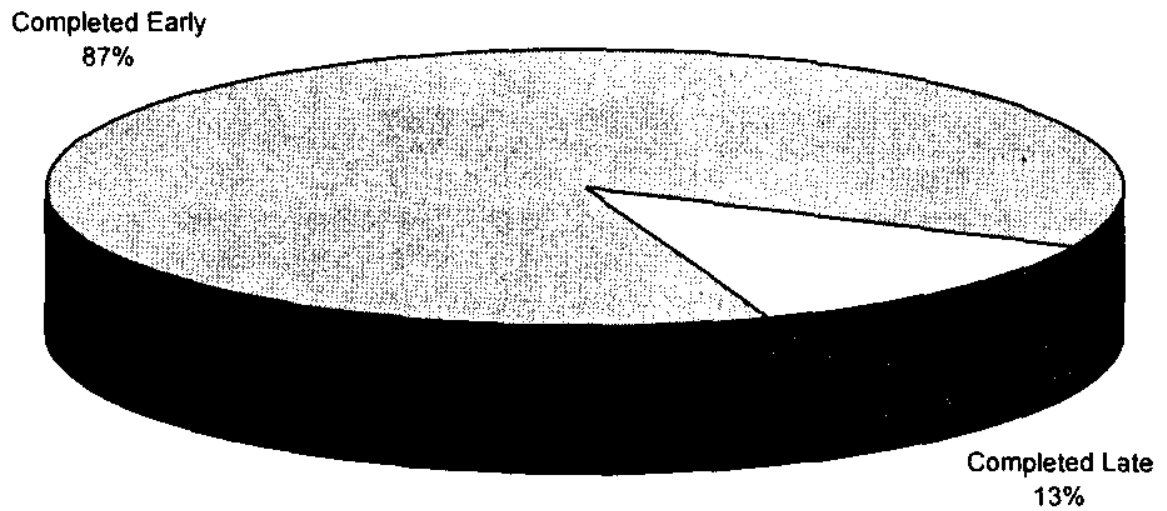

RL

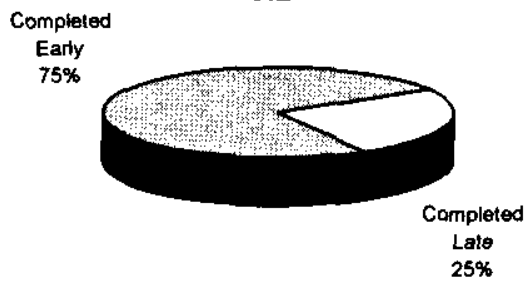

Enforceable Agreement

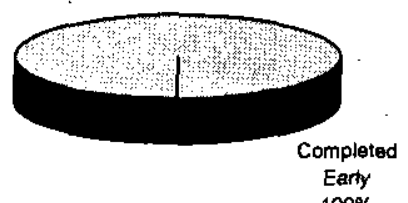

\section{MILESTONE EXCEPTION REPORT}

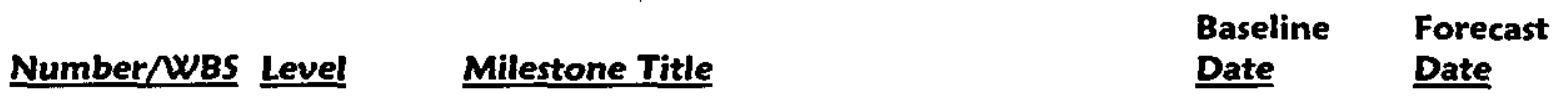

\section{OVERDUE - 0}

FORECAST LATE - 0 

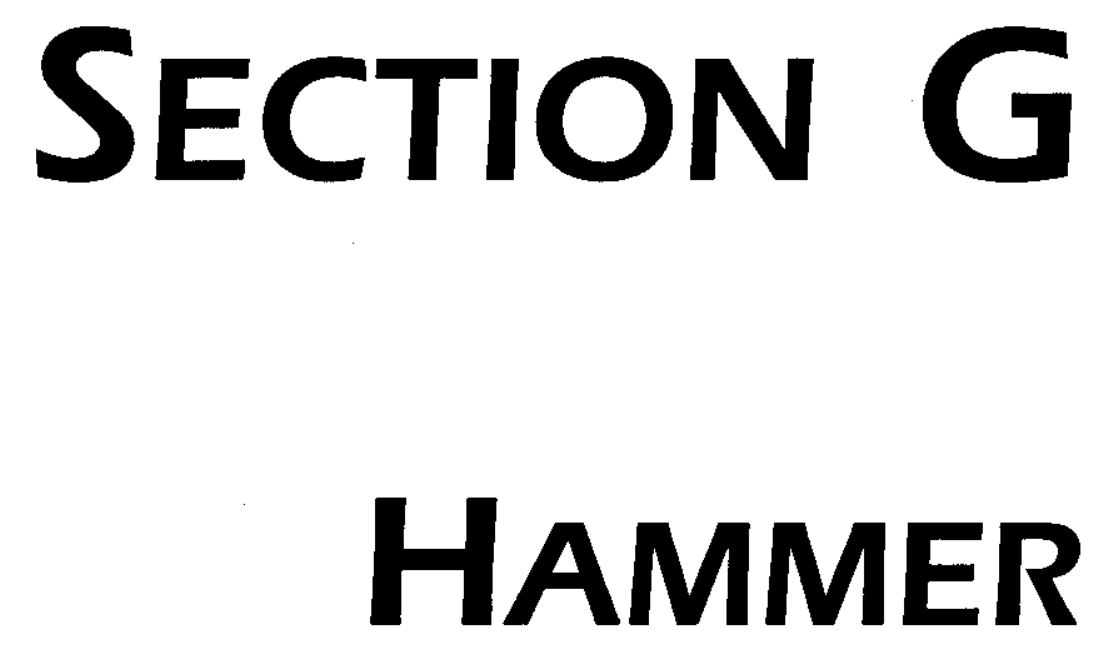

\title{
AS OF DECEMBER 31, 1999
}

PROGRAM MANAGERS

\author{
J. E. Ollero, RL \\ Phone: (509) 376-3825
}

\author{
K. A. McGinnis, FH \\ Phone: (509) 376-9403
}




\section{SUMMARY}

The Hazardous Materials Management and Emergency Response (HAMMER) mission area consists of the HAMMER project, WBS 1.9.1.1, Project Baseline Summary (PBS) HM01.

Volpentest HAMMER's first priority is to deliver hands-on training to the Hanford workforce. During December ninety-three classes were conducted at the Volpentest HAMMER facility, for a total of 1,548 Hanford site student days. Highest attended health and safety classes included Hazardous Waste Operations, Respiratory Protection, Radiation Worker II Requalification, Basic Medic First Aid and Fire Extinguisher Training. Overall satisfaction, rated on a scale of 1 to 5 based on level one evaluations, for the month of December: Course Content 4.42, Instructor(s) 4.59, and Facility 4.49.

A total of four Hanford site Emergency Preparedness training courses were presented during December with a total of 41 students receiving training. Emergency Preparedness classes presented included the Hanford Incident Command System, Building Emergency Director, and Building Warden training courses.

The HAMMER Emergency Preparedness (EP) training coordinator instructed the Building Warden Initial training (Course \#037500) on December 14, 1999, to become a qualified instructor of the Building Warden training course. The qualification was obtained to provide backup support to the EP Representative who routinely instructs this course. A special request was received to provide Hanford Incident Command System and Building Emergency Director training to Spent Nuclear Fuels (SNF) personnel. These two special sessions were held at the $100-\mathrm{K}$ training trailer to assist SNF with a training issue.

Baseline Change Request \#HMR-2000-001 was submitted to DOE-RL on December 15, 1999. This change request incorporates critical FY 1999 carryover workscope and additional new FY 2000 workscope into the baseline.

During December the Benton County Sheriff's Office conducted three sessions of their annual mini patrol academy at HAMMER's Law Enforcement and Security Training Center. This year's academy included a four hour block of instruction on first aid training for law enforcement officers, which was provided by a Hanford Patrol Instructor. The last academy session concluded on December 15, 1999 and approximately 40 deputies attended.

On December 15 - 17, 1999, the HAMMER NCC program, in partnership with the Florida National Guard's Multijurisdictional Counterdrug Task Force Training program, hosted a Drug Interdiction and Investigative Techniques for the Patrol Officer's course for federal, state and local law enforcement officers. Forty-three officers representing agencies from throughout the Pacific Northwest Region attended the course, which was a huge success.

Milestone performance (EA, DOE-HQ, and RL) shows that there are no milestones due fiscal year-to-date. 


\section{ACCOMPLISHMENTS}

- Trained 1,548 Hanford site student days at HAMMER. (Planned)

- Presented four Hanford site Emergency Preparedness training courses. (Planned)

- HAMMER EP training coordinator obtains qualification as an instructor for the Building Warden training course. (Planned)

- Submitted Baseline Change Request \#HMR-2000-001 to DOE-RL. (Planned)

- Benton Country Sheriff's Office utilizes the HAMMER Law Enforcement and Security Training Center to conduct a mini patrol academy. (Planned)

- Hosted a Drug Interdiction and Investigative Techniques for the Patrol Officer's course for federal, state and local law enforcement officers. (Planned)

\section{Cost Performance (\$M):}

\begin{tabular}{|l|c|c|c|}
\hline & BCWP & ACWP & VARIANCE \\
\hline HAMMER & $\$ 1.3$ & $\$ 1.2$ & $\$ 0.0^{*}$ \\
\hline
\end{tabular}

*Rounding

The cost variance is insignificant.

Schedule Performance (\$M):

\begin{tabular}{|l|c|c|c|}
\hline & BCWP & BCWS & VARIANCE \\
\hline HAMMER & $\$ 1.3$ & $\$ 1.3$ & $\$ 0.0$ \\
\hline
\end{tabular}

The schedule variance is insignificant.

\section{ISSUES}

Nothing to report. 
FY 2000 COST/SCHEDULE PERFORMANCE - ALL FUND TYPES Cumulative to Date Status
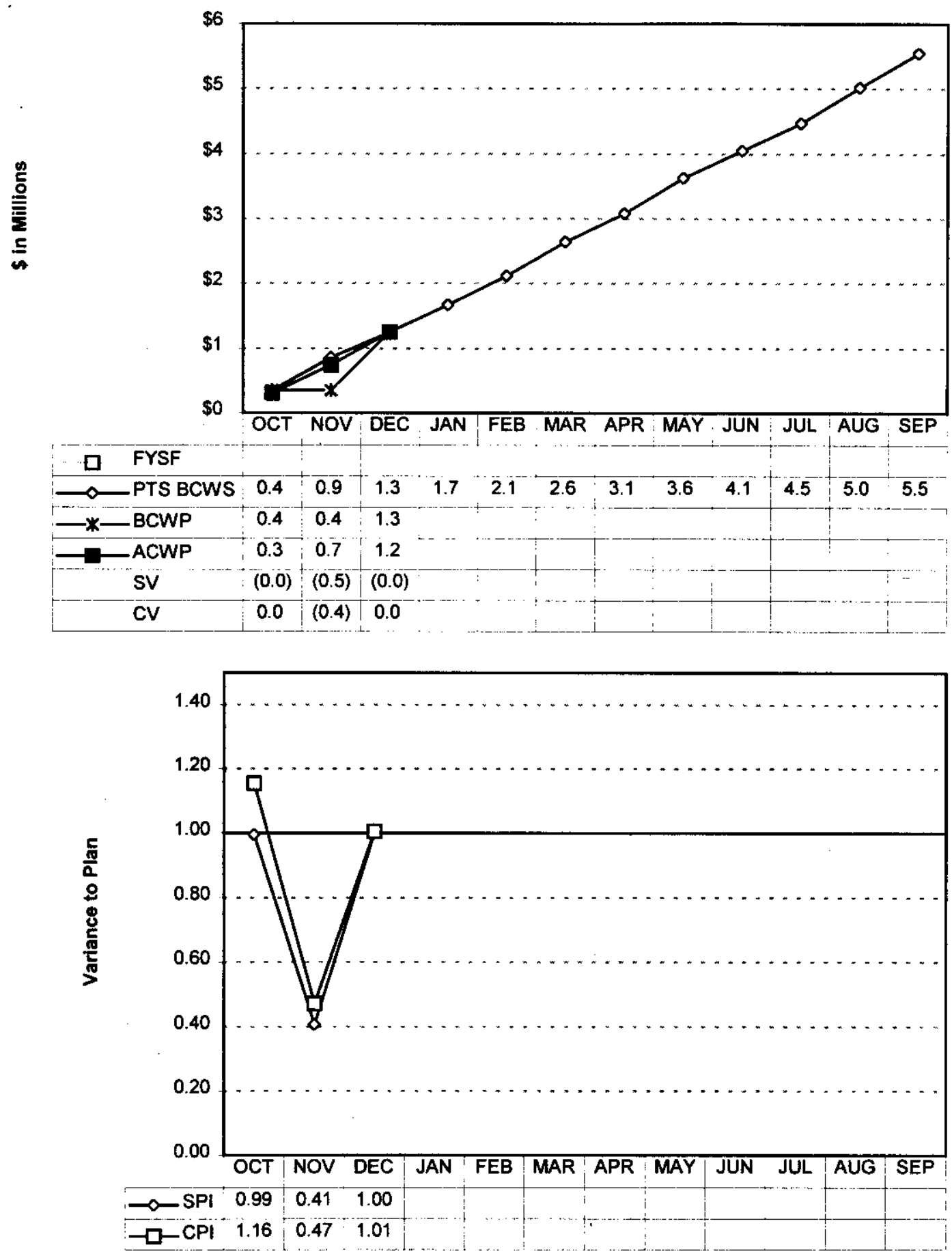


\section{HAMMER \\ WBS 1.9}

\begin{tabular}{|c|c|c|c|c|c|c|c|c|}
\hline & \multicolumn{5}{|c|}{ FYTD } & \multirow{2}{*}{$\begin{array}{l}\text { AUTH } \\
\text { BSLN }\end{array}$} & \multirow{2}{*}{$\begin{array}{r}\text { PTS } \\
\text { BCWS }\end{array}$} \\
\hline & & BCWS & BCWP & ACWP & sv & CV & & \\
\hline \multicolumn{9}{|l|}{ PBS } \\
\hline \multirow[t]{4}{*}{ HM01 HAMMER } & Expense & 1.3 & 1.3 & 1.2 & $(0.0)$ & 0.0 & 5.5 & 5.5 \\
\hline & CENRTC & 0.0 & 0.0 & 0.0 & 0.0 & 0.0 & 0.0 & 0.0 \\
\hline & GPP/LI & 0.0 & 0.0 & 0.0 & 0.0 & 0.0 & 0.0 & 0.0 \\
\hline & ER & $\frac{.0}{1.3}$ & 1.3 & $\overline{1.2}$ & $(\overline{0.0})$ & 0.0 & 5.5 & 5.5 \\
\hline
\end{tabular}

\section{COST VARIANCE ANALYSIS: $(\$ 0.0 \mathrm{M})$}

\section{$\underline{\text { WBS/PBS }}$ TITLE}

\subsubsection{1/HM01 HAMMER}

Description and Cause: There is no variance.

Impact: None.

Corrective Action: None.

\section{SCHEDULE VARIANCE ANALYSIS: (\$0.0M)}

WBS $\underline{\text { TITLE }}$

\subsubsection{1/HMO1 HAMMER}

Description and Cause: There is no variance.

Impact: None.

Corrective Action: None. 


\section{HAMMER - WBS 1.9 \\ MILESTONE ACHIEVEMENT}

\begin{tabular}{|c|c|c|c|c|c|c|c|c|}
\hline \multirow[b]{2}{*}{ MILESTONE TYPE } & \multicolumn{4}{|c|}{ FISCAL YEAR-TO-DATE } & \multicolumn{3}{|c|}{ REMAINING SCHEDULED } & \multirow[b]{2}{*}{$\begin{array}{c}\text { TOTAL } \\
\text { FY } 2000\end{array}$} \\
\hline & $\begin{array}{c}\text { Completed } \\
\text { Early }\end{array}$ & $\begin{array}{c}\text { Completed } \\
\text { On } \\
\text { Schedule }\end{array}$ & $\begin{array}{c}\text { Completed } \\
\text { Late }\end{array}$ & Overdue & $\begin{array}{c}\text { Forecast } \\
\text { Early }\end{array}$ & $\begin{array}{c}\text { Forecast } \\
\text { On } \\
\text { Schedule }\end{array}$ & $\begin{array}{c}\text { Forecast } \\
\text { Late }\end{array}$ & \\
\hline Enforceable Agreement & 0 & 0 & 0 & 0 & 0 & 0 & 0 & $\overline{0}$ \\
\hline DOE-HQ & 0 & 0 & 0 & 0 & 0 & 0 & 0 & 0 \\
\hline FO & 0 & 0 & 0 & 0 & 0 & 0 & 0 & 0 \\
\hline $\mathrm{RL}$ & 0 & 0 & 0 & 0 & 0 & 5 & 0 & 5 \\
\hline Total Project & 0 & 0 & 0 & 0 & 0 & 5 & 0 & 5 \\
\hline
\end{tabular}

\section{MILESTONE EXCEPTION REPORT}

$\begin{array}{lll}\text { Number/WBS Level Milestone Title } & \underline{\text { Baseline Forecast }} \\ \text { Date } & \underline{\underline{\text { Date }}}\end{array}$

Overdue - 0

Forecast LATE - 0 
Environmental Management Performance Report-December 1999

Section $\mathrm{H}$-Advanced Reactors Transition Program (ART)
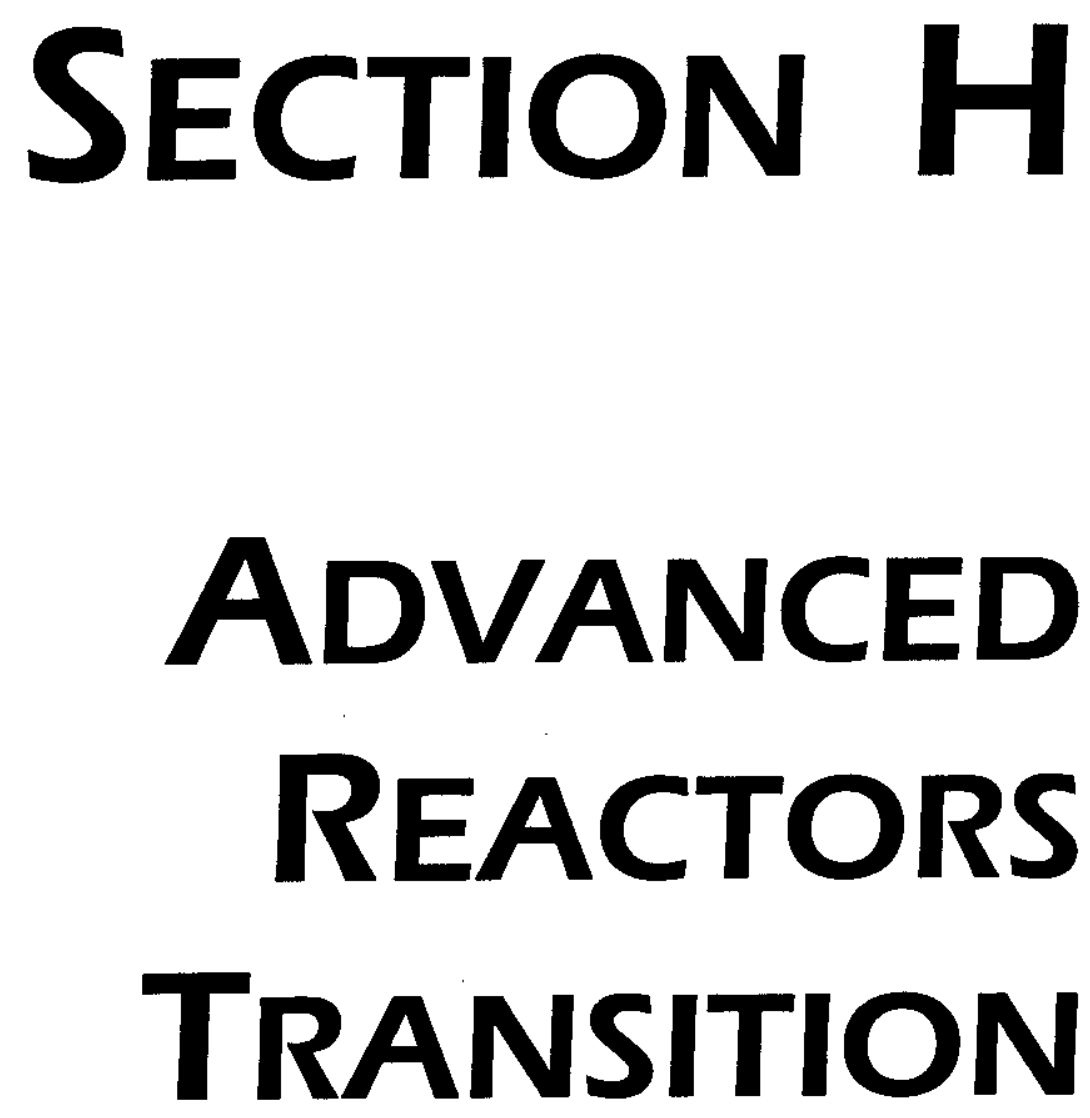

\title{
As OF DeCEMBER 3 1, 1999
}

Project Managers

\author{
O. A. Farabee, RL \\ Phone: (509) 376-8089 \\ D. B. KIos, FDH \\ Phone: (509) 373-3574
}




\section{SUMMARY}

The Advanced Reactors Transition (ART) Program, WBS 1.12.1.1, PBS RL-TP11, consists of the 309 Building and the Nuclear Energy (NE) Legacies activities. The operation of the Fast Flux Test Facility (FFTF) is funded by DOE-Nuclear Energy and is not included in this report on RL EM funded activities. FFTF performance is reported separately by RL to DOE-NE.

In December the ART mission area technical accomplishments included continued surveillance and maintenance activities on the 309 Building and NE legacies. Progress continued on cleaning sodium residuals from a tank from the 221-T Building.

Fiscal-year-to-date milestone performance (EA, DOE-HQ, and RL) shows that there are no milestones due.

\section{ACCOMPLISHMENTS}

- $\quad$ Continued surveillance and maintenance activities on 309 Building and NE legacies. (Planned)

- Good progress continued on cleaning sodium residuals from a tank from the 221-T Building. (Planned)

\section{Cost Performance $(\$ M):$}

\begin{tabular}{|l|c|c|c|}
\hline & BCWP & ACWP & VARIANCE \\
\hline Advanced Reactors Transition & $\$ 0.3$ & $\$ 0.3$ & $+\$ 0.0$ \\
\hline
\end{tabular}

There is no significant cost variance.

\section{Schedule Performance (\$M):}

\begin{tabular}{|l|c|c|c|}
\hline & BCWP & BCWS & VARIANCE \\
\hline Advanced Reactors Transition & $\$ 0.3$ & $\$ 0.3$ & $+\$ 0.0$ \\
\hline
\end{tabular}

There is no significant schedule variance.

\section{ISSUES}

Additional funding to support the completion of the deactivation activities will provide a benefit of significantly reduced surveillance and maintenance costs. 


\section{ADVANCED REACTORS TRANSITION WBS 1.12}

\section{FY 2000 COST/SCHEDULE PERFORMANCE - ALL FUND TYPES Cumulative to Date Status}
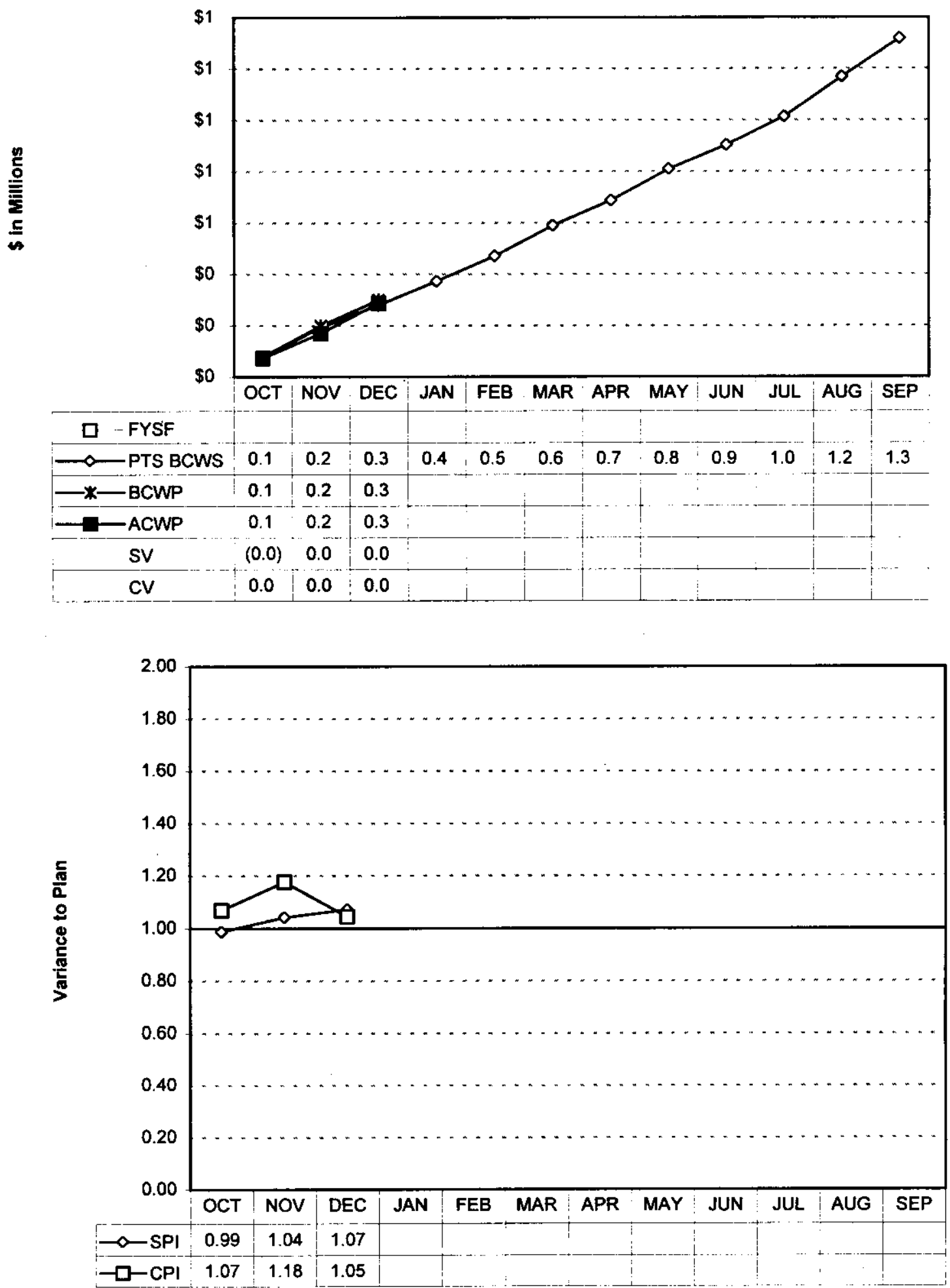


\section{ADVANCED REACTORS TRANSITION WBS 1.12}

PBS

TP11 Advanced Reactors
(1)
CENRTC GPP/LI

Total

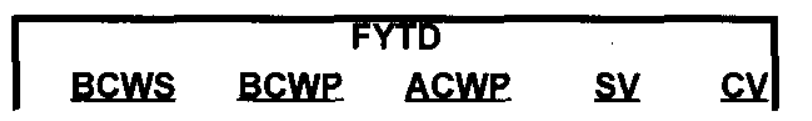

AUTH PTS

BSLN BCWS

\begin{tabular}{ll}
1.3 & 1.3 \\
0.0 & 0.0 \\
0.0 & 0.0 \\
\hline 1.3 & 1.3
\end{tabular}

\$ In Millions

\section{Cost VARIance ANAlysis: $(+\$ 0.0 \mathrm{M})$}

\section{WBS/PBS}

1.12/TP11

Description a

Impact: None.

Corrective Action: None.

\section{Title}

Advanced Reactors Transition

\section{SCHEDUle VARIANCE ANALYsIS: (+\$0.0M)}

\section{$\underline{\text { WBS/PBS } \quad \text { Title }}$}

1.12/TP11 Advanced Reactors Transition

Description and Cause: None.

Impact: None.

Corrective Action: None.

\section{MILESTONE EXCEPTION REPORT}
Number/WBS
Level Milestone Title
Baseline
Date
Forecast
OVERdue - 0

FORECAST LATE - 0 

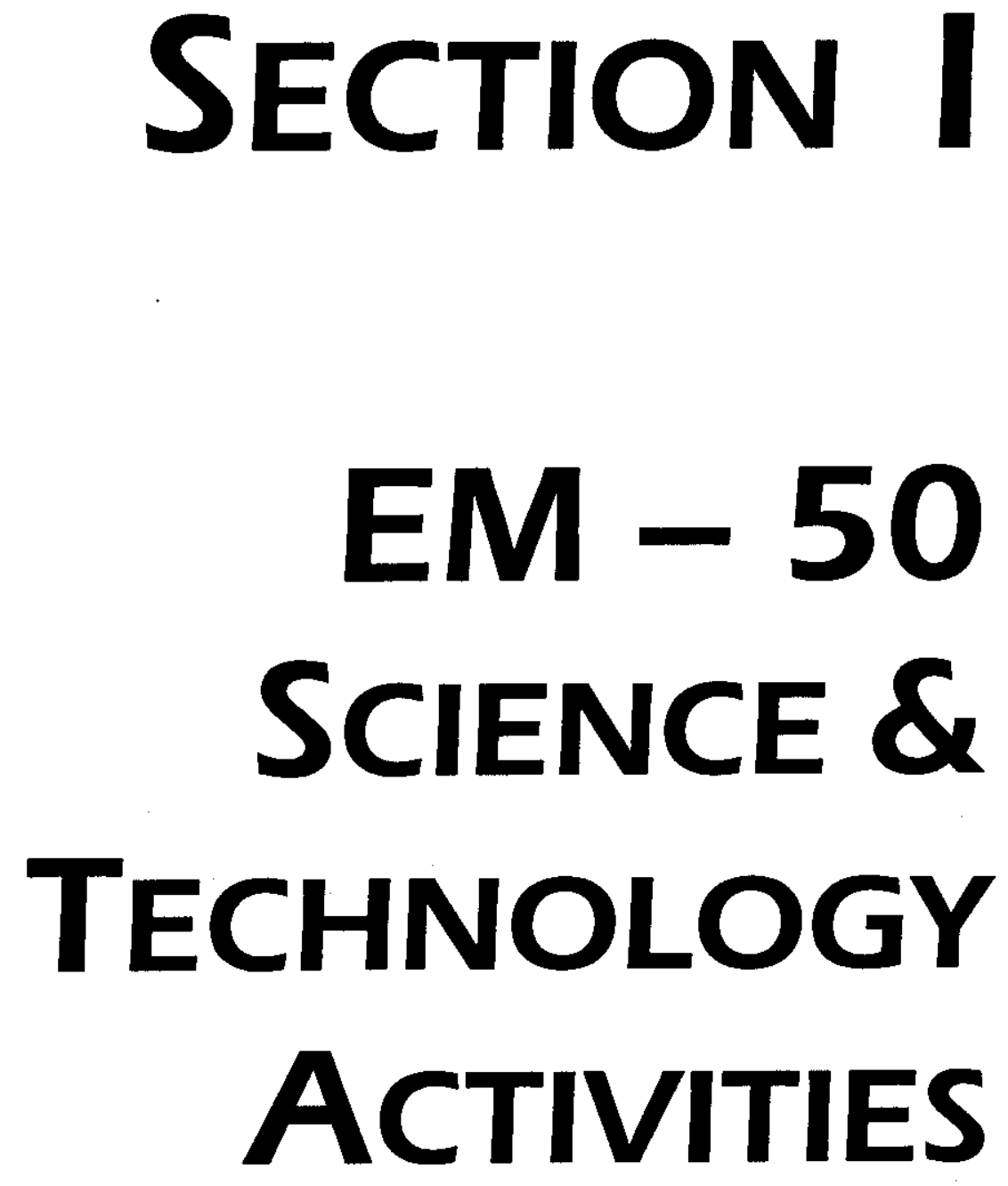

As OF DECEMBER 31, 1999 
EM-50

MILESTONE ACHIEVEMENT

\begin{tabular}{|c|c|c|c|c|c|c|c|c|}
\hline \multirow[b]{2}{*}{$\begin{array}{l}\text { MILESTONE } \\
\text { TYPE }\end{array}$} & \multicolumn{4}{|c|}{ FISCAL YEAR-TO-DATE } & \multicolumn{3}{|c|}{ REMAINING SCHEDULED } & \multirow[b]{2}{*}{$\begin{array}{c}\text { TOTAL } \\
\text { FY } \\
2000\end{array}$} \\
\hline & $\begin{array}{l}\text { Completed } \\
\text { Early }\end{array}$ & $\begin{array}{l}\text { Completed } \\
\text { On } \\
\text { Schedule }\end{array}$ & $\begin{array}{c}\text { Completed } \\
\text { Late }\end{array}$ & Overdue & $\begin{array}{l}\text { Forecast } \\
\text { Early }\end{array}$ & $\begin{array}{l}\text { Forecast } \\
\text { On } \\
\text { Schedule }\end{array}$ & $\begin{array}{l}\text { Forecast } \\
\text { Late }\end{array}$ & \\
\hline $\begin{array}{l}\text { Enforceable } \\
\text { Agreement }\end{array}$ & 0 & c & 0 & 0 & 0 & 0 & 0 & \\
\hline DOE-HQ & 0 & 0 & 0 & 0 & 0 & 13 & 4 & \\
\hline FO & 0 & 0 & 0 & 0 & 0 & 0 & 0 & \\
\hline $\mathbf{R L}$ & 2 & 1 & 0 & 6 & 0 & 49 & 8 & 0 \\
\hline Total Project & 2 & 1 & 0 & 6 & 0 & 62 & 12 & 83 \\
\hline
\end{tabular}

Total Project

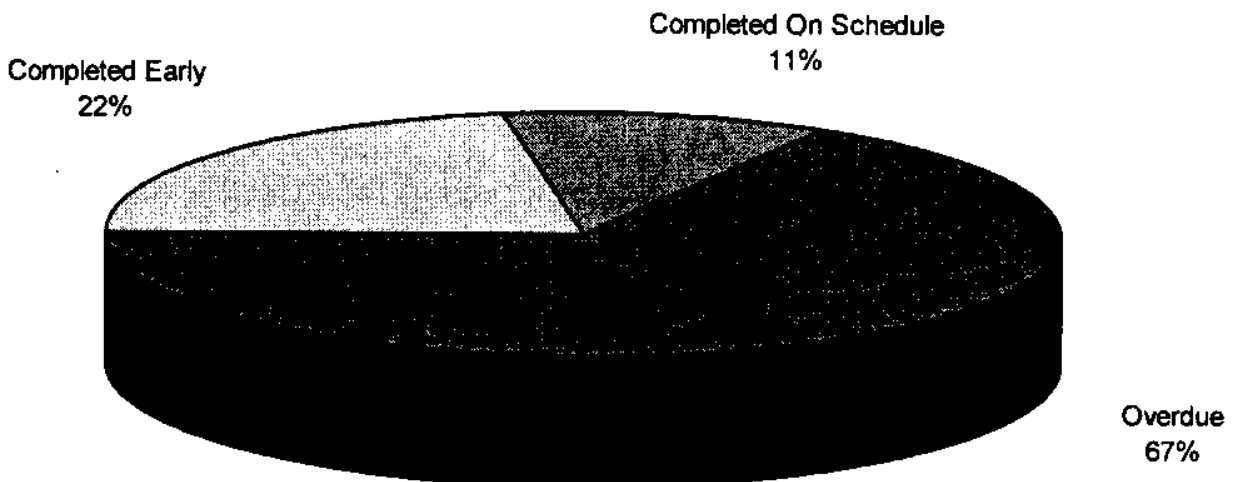

RL

Completed

Completed Early On Schedule

$22 \% \quad 11 \%$

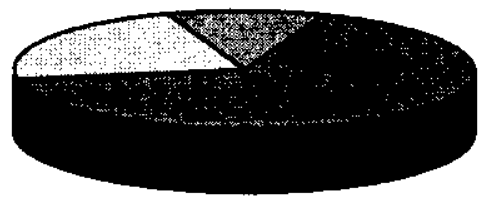

Overdue

$67 \%$ 


\section{EM-50 Exceptions}

\section{Number Level Milestone Title \\ Baseline forecast}

OVERDUE - 6

009DD61/3 RL Award Contract for Robotic Work 10/15/99 1/31/00

2.1.1 (AMT) Platform

Cause: RFP was sent out to all potential vendors. Review of submittals has delayed issuance of the contract.

Impact: None

Corrective Action: The contract will be awarded in January 2000.

49MW21/C-2 RL Produce Report Mapping the Matrix Space 11/15/99 Proposed

2.1.1 (AMT) in Hanford Waste Boxes Deletion

Cause: Activities at WRAP were focused on preparing shipments to WIPP.

Impact: None

Corrective Action: Funding for this TTP was returned to the Mixed Waste Focus Area. This task is cancelled.

49MW21/B-4 RL Issue Software Test Reports 12/01/99 Proposed

2.1.1 (AMT) in Hanford Waste Boxes - Deletion

Cause: Activities at WRAP were focused on preparing shipments to WIPP.

Impact: None

Corrective Action: Funding for this TTP was returned to the Mixed Waste Focus Area. This task is cancelled.

09WT22/C11 RL Issue Hanford Data Requirements for 12/15/99 03/31/00

\subsection{1 (AMT) Operational Improvement Tests}

Cause: Projects are reviewing user needs for this activity.

Impact: None

Corrective Action: The Tanks Focus Area, ORP, and CH2M Hill are discussing redefinition of scope, assignment and funding for this task. As soon as this task is redefined, a change request and revised TTP will be submitted.

09WT22/C41 RL Issue Func. Requirements for Variable 12/15/99 03/31/00

\subsection{1 (AMT) Depth Transfer Pump}

Cause: Projects are reviewing user needs for this activity.

Impact: None

Corrective Action: The Tanks Focus Area, ORP, and CH2M Hill are discussing redefinition of scope, assignment and funding for this task. As soon as this task is redefined, a change request and revised TTP will be submitted. 
008WT51/1 RL Issue Product Delivery Expectations on $12 / 15 / 99 \quad 02 / 10 / 00$.

2.1.1 (AMT) Technologies for Remote Pit Enhancements

Cause:

Impact: None

Corrective Action: The Memorandum of Understanding is in the process of being established.

A River Protection Project Project Manager has been selected. This milestone will be complete in February, 2000.

\section{FORECAST DELAY - 12}

\begin{tabular}{|c|c|c|}
\hline $\begin{array}{l}\text { 030C211/A01 HQ } \\
\text { 3.5.6 (AMT) }\end{array}$ & $\begin{array}{l}\text { Complete Comprehensive Report on } \\
\text { Instrument Development }\end{array}$ & $9 / 30 / 00$ \\
\hline
\end{tabular}

Cause: This milestone has been delayed because prerequisite decision requirements for the separation process have not yet been made, and are not expected until the middle of January 2000.

Impact: None

Corrective Action: A revised TTP will be generated after replanning is completed.

\begin{tabular}{|c|c|}
\hline $\begin{array}{l}\text { 030C211/A11 HQ } \\
3.5 .6 \text { (AMT) }\end{array}$ & $\begin{array}{l}\text { Complete Demonstration of Gamma } \\
\text { Snectrometer }\end{array}$ \\
\hline
\end{tabular}

Cause: This milestone has been delayed because prerequisite decision requirements for the separation process have not yet been made, and are not expected until the middle of January 2000.

Impact: None

Corrective Action: A revised TTP will be generated after replanning is completed.
$030 \mathrm{C} 211 / \mathrm{A} 21 \mathrm{HQ}$
Complete Demonstration of Neutron
$4 / 30 / 00$
$9 / 30 / 00$
3.5.6 (AMT)
Counting System

Cause: This milestone has been delayed because prerequisite decision requirements for the separation process have not yet been made, and are not expected until the middle of January 2000.

Impact: None

Corrective Action: A revised TTP will be generated after replanning is completed.

09WT22/A11 RL Complete Functional Requirements for 3/10/00 6/30/00

\subsection{1 (AMT) Sluicing of Tanks Beyond C-1}

$$
3 / 10 / 00 \quad 6 / 30 / 00
$$

Cause: Projects are reviewing user needs for this activity

Impact: None

Corrective Action: The Tanks Focus Area, ORP, and $\mathrm{CH} 2 \mathrm{M}$ Hill are discussing redefinition of scope, assignment and funding for this task. As soon as this task is redefined, a change request and revised TTP will be submitted. 
09WT22/C21 RL Complete Functional Requirements for 4/30/00 7/31/00

\subsection{1 (AMT) Sluicing of Tanks Beyond C-1}

Cause: Projects are reviewing user needs for this activity

Impact: None

Corrective Action: The Tanks Focus Area, ORP, and $\mathrm{CH} 2 \mathrm{M}$ Hill are discussing redefinition of scope, assignment and funding for this task. As soon as this task is redefined, a change request and revised TTP will be submitted.

09WT22/C31 RL Complete Functional Requirements for 4/30/00 7/31/00

\subsection{1 (AMT) Sluicing of Tanks Beyond C-1}

Cause: Projects are reviewing user needs for this activity

Impact: None

Corrective Action: The Tanks Focus Area, ORP, and $\mathrm{CH} 2 \mathrm{M}$ Hill are discussing redefinition of scope, assignment and funding for this task. As soon as this task is redefined, a change request and revised TTP will be submitted.
035C223/A11 HQ
Project Review
$2 / 11 / 00$
$3 / 31 / 00$

3.5.6 (AMT) Issue Phase D Test Report

Cause: Project review date has been delayed by Subsurface Contaminants Focus Area to midMarch.

Impact: None

Corrective Action: Change Request \# PTD00-011 has been submitted to RL to revise the milestone date.

036WT51/A14 RL Complete Test of 50-HP Flygt Mixer and 1/30/00 4/30/00 3.5.4 (AMT) Issue Phase D Test Report

Cause: During November, a preliminary test of the Flygt Mixer was conducted to check out the test system \& the DAS. A propeller blade failed during a water operation on Nov $17,1999 \&$ will be replaced mid-January. Due to this delay, the mixer run-in test cannot be completed on schedule.

Impact: None

Corrective Action: A change request will be submitted to delay this milestone completion date.

037C131/A11 RL Participate in the AEAT Outline Design $3 / 31 / 00 \quad 06 / 30 / 00$ 3.5.6 (AMT) Review

Cause: PNNL staff activities are currently on hold until activities are kicked off for the parent program, the Nested, Fixed-Depth Fluidic Sampler and At-Tank Analysis System Program, RL08WT22.

Impact: None

Corrective Action: Milestone will be revised upon resolution of RL08WT22.

037C131/A12 RL Issue Letter Report on Nested Sampler $\quad 7 / 15 / 00 \quad 10 / 15 / 00$ 3.5.6 (AMT) Cold Test Recommendations

Cause: PNNL staff activities are currently on hold until activities are kicked off for the parent program, the Nested, Fixed-Depth Fluidic Sampler and At-Tank Analysis System Program, RL08WT22.

Impact: None

Corrective Action: Milestone will be revised upon resolution of RL08WT22. 
$\begin{array}{llll}\text { 037C131/B11 RL } & \text { Issue Design Recommendations and } & 2 / 15 / 00 & 7 / 15 / 00 \\ \text { 3.5.6 (AMT) } & \text { Specifications for Enhanced Pit Operations } & \end{array}$

Cause: PNNL staff are under a hold for technical activities pending authorization of support

funding on the W-314 Project/Tank Farm Operations side.

Impact: None

Corrective Action: Milestone will be revised upon resolution of W-314.

037WT31/B32 RL Issue Next "Phase" Test Matrix for 1/30/00 3/30/00

\subsection{4 (AMT) INEEL CVS Study}

Cause: Task will begin once projected waste compositions are available from INEEL. This input was scheduled by the end of November and hasn't yet been delivered. The status was discussed in a meeting with the end-users, the TFA TIM and co-investigators. The current scheduled completion date of $3 / 30 / 00$.

Impact: None

Corrective Action: This milestone will be completed by March 30, 2000. Task will begin once projected waste compositions are available form INEEL.

\section{OVERDUE - 3 (FY 1999)}

$\begin{array}{llll}\text { 08WT21/C1 HQ } & \begin{array}{l}\text { Document Deployment of the Corrosion } \\ \text { 2.1.1 (AMT) }\end{array} & \text { Probe }\end{array}$

Cause: Tank Farm Operations priorities and work package review issues have delayed this task until January 2000.

Impact: None

Corrective Action: The probe will be deployed January 13, 2000.

08WT22/H-1 RL Issue Revised Deployment Strategy 8/30/99 2/28/00 2.1.1 (AMT) and Plan

Cause: The strategy of this task has been modified to include a mobile sampler system, which has caused the revision of this plan to be delayed.

Impact: None

Corrective Action: This plan will be issued by $2 / 28 / 00$.

49MW21/A-2 RL Submit BWAS Characterization Plan 8/31/99 Proposed

2.1.1 (AMT)

Deletion

Cause: Activities at WRAP were focused on preparing shipments to WIPP.

Impact: None

Corrective Action: Funding for this TTP was returned to the Mixed Waste Focus Area. This task is cancelled. 

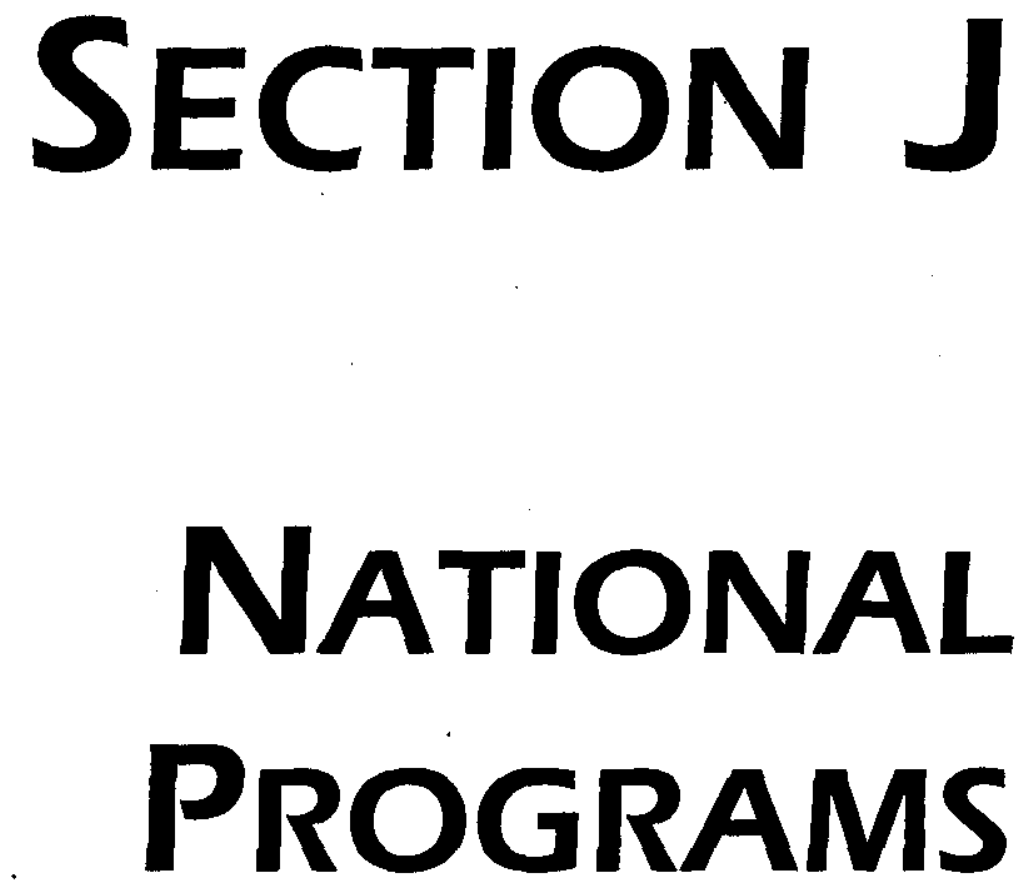

As OF DECEMBER 31, 1999 


\section{Introduction to National Programs}

DOE EM is responsible for a variety of National Programs. DOE-HQ typically provides operations policy and programmatic guidance to one or more field office that serve as lead for individual programs. FH currently supports the following National Programs: Transportation and Packaging (PBS OT02), Pollution Prevention and Waste Minimization (PBS WM07), and Emergency Preparedness (PBS OT06).

Transportation and Packaging provides full-service transportation and packaging capabilities. Packaging services for radioactive and hazardous cargo is provided, including regulatory safetybasis documentation, certification, and licensing. Packaging plans and logistical studies for major shipping campaigns are also provided, as well as approved training courses in transportation safety and waste management. Transportation and traffic logistics management, engineering and operational support to offsite customers, carrier selection and evaluation, automated transportation management systems used by the U.S. Department of Energy (DOE) complex and commercial vendors, and international transport of hazardous and radioactive packages are other services provided.

Pollution Prevention and Waste Minimization (P2/WMin) coordinates the development and implementation of a Hanford Site P2/WMin Program to comply with Federal, state, and DOE directives. The program's purpose is to achieve Site objectives through effective and efficient methodologies tailored to generator activities and operations.

The Emergency Preparedness workscope is under the direction of the DOE National Transportation Program. This training program (coordinated through HAMMER) offers consistent training necessary for the DOE complex to meet the changing requirements for safe and compliant transport of hazardous materials. 

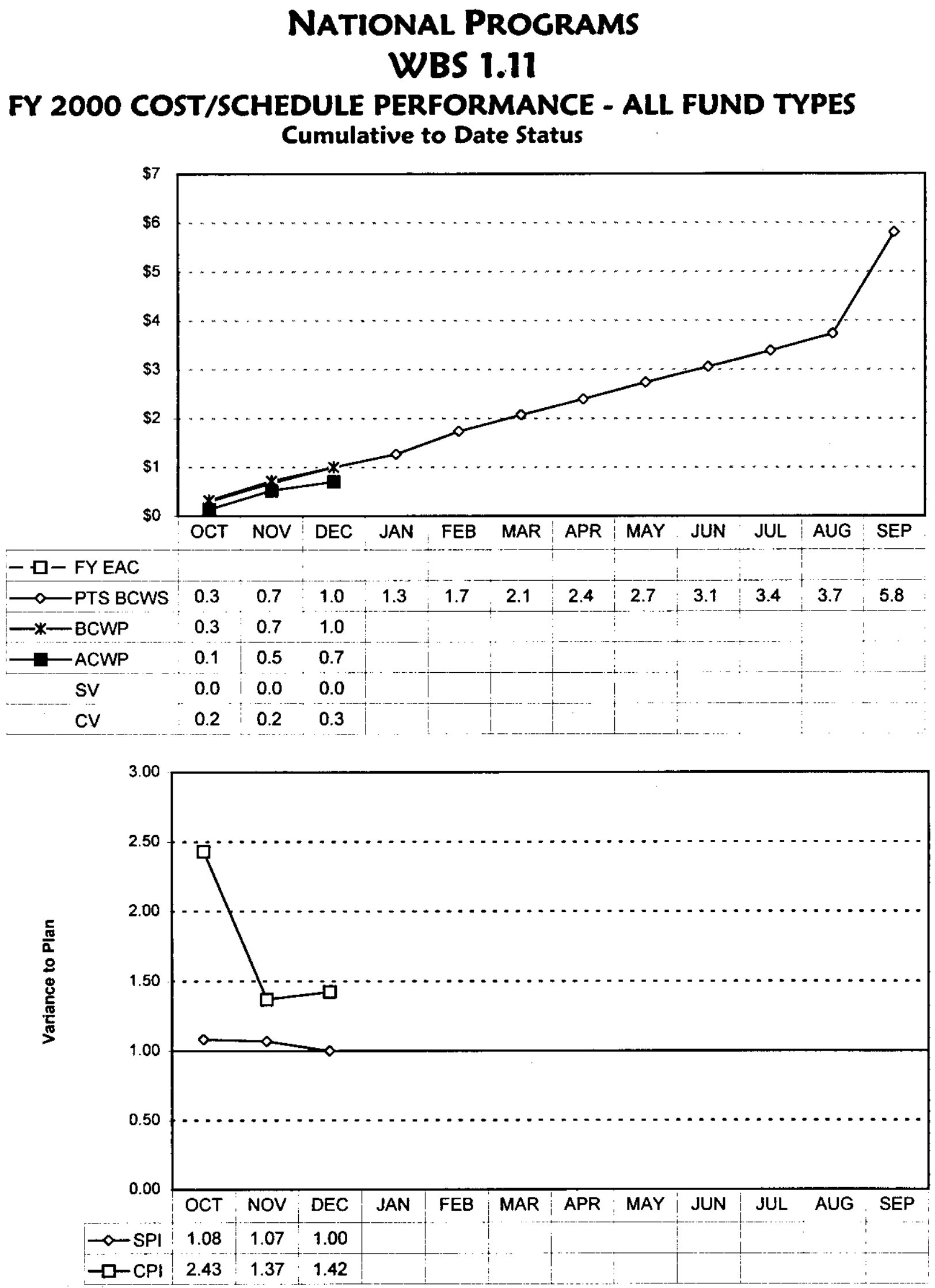


\section{National Programs WBS 1.11}

\begin{tabular}{|c|c|c|c|c|c|c|c|c|c|}
\hline \multirow{2}{*}{1.11} & & & \multicolumn{5}{|l|}{ FYTD } & \multirow{2}{*}{$\begin{array}{l}\text { AUTH } \\
\text { BSLN }\end{array}$} & \multirow{2}{*}{$\begin{array}{r}\text { PTS } \\
\text { BCWS }\end{array}$} \\
\hline & & & BCws & BCWP & ACWP & sv & cV & & \\
\hline \multicolumn{10}{|l|}{ PBS } \\
\hline \multirow[t]{4}{*}{ От02 } & Transportation & Expense & 0.5 & 0.5 & 0.2 & 0.0 & 0.3 & 0.0 & 2.0 \\
\hline & \& Packaging & CENRTC & 0.0 & 0.0 & 0.0 & 0.0 & 0.0 & 0.0 & 0.0 \\
\hline & & GPP/LI & 0.0 & 0.0 & 0.0 & 0.0 & 0.0 & 0.0 & $\underline{0.0}$ \\
\hline & Sub-T & tal OT02 & 0.5 & 0.5 & 0.2 & 0.0 & 0.3 & 0.0 & 2.0 \\
\hline \multirow[t]{4}{*}{ WM07 } & Waste & Expense & 0.5 & 0.5 & 0.3 & 0.0 & 0.2 & 3.8 & 3.8 \\
\hline & Minimization & CENRTC & 0.0 & 0.0 & 0.0 & 0.0 & 0.0 & 0.0 & 0.0 \\
\hline & & GPP/LI & $\underline{0.0}$ & 0.0 & 0.0 & 0.0 & 0.0 & 0.0 & 0.0 \\
\hline & Sub-T & tal WM07 & 0.5 & 0.5 & 0.3 & 0.0 & 0.2 & 3.8 & 3.8 \\
\hline \multirow[t]{8}{*}{ OT06 } & Emergency & Expense & 0.0 & 0.0 & 0.2 & 0.0 & $(0.2)$ & 0.0 & 0.0 \\
\hline & Preparedness & CENRTC & 0.0 & 0.0 & 0.0 & 0.0 & 0.0 & 0.0 & 0.0 \\
\hline & & GPP/LI & 0.0 & 0.0 & 0.0 & $\underline{0.0}$ & 0.0 & $\underline{0.0}$ & 2.0 \\
\hline & Sub-T & tal OT06 & 0.0 & 0.0 & 0.2 & 0.0 & $(0.2)$ & 0.0 & 0.0 \\
\hline & Total & Expense & 1.0 & 1.0 & 0.7 & 0.0 & 0.3 & 3.8 & 5.8 \\
\hline & & CENRTC & 0.0 & 0.0 & 0.0 & 0.0 & 0.0 & 0.0 & 0.0 \\
\hline & & GPP/LI & 0.0 & 0.0 & 0.0 & Q. & 0.0 & 0.0 & 0.0 \\
\hline & Total & . & 1.0 & 1.0 & 0.7 & 0.0 & 0.3 & 3.8 & 5.8 \\
\hline
\end{tabular}




\section{GLOSSARY}

Actual cost of work performed (ACWP): The actual cost incurred and applied or distributed for the work performed within a given time period. It includes all labor categories, material, any other direct costs, subcontract work, and function overhead.

Approved baseline: The budget authorized to perform the workscope that has been agreed upon by the customer and the contractor(s). It is portrayed in the Multi-Year Work Plan with all approved changes. This baseline may or may not be fully funded, and could be more or less than the compliance baseline.

Budget at completion (BAC): The sum of budgets established to complete a program and/or project or any component of a program and/or project.

Budgeted cost of work performed (BCWP): The value for completed work measured in terms of the planned budget for that work. It is synonymous with earned value.

Budgeted cost of work scheduled (BCWS): The time-phased budgeted value of work scheduled to be accomplished over a given time period. The BCWS for a total cost account through its entire period of performance is equal to the BAC for the cost account.

Carryover Workscope: The estimated dollar amount of the workscope that was not completed during the fiscal year and which will be carried over and completed in the next fiscal year.

Compliance baseline: The budget that is required to perform the workscope necessary to be in compliance with State and Federal regulations, enforceable agreement milestones, and DNFSB milestones. The level of activity required to be in compliance assumes sufficient funding. Note: Because approved baselines are considered to be compliant, this column will likely be eliminated.

Contract Inherited: The assumed budget for the planned scope of work at the time a new contract is signed by the company responsible for performing the work.

Cost variance (CV): The difference between $B C W P$ and $A C W P(C V=B C W P-A C W P)$. At any time, it shows whether the work actually performed has cost more or less than the amount budgeted for the same work.

Cost Performance Indicator (CPI): The CPI is the ratio of BCWP to ACWP, or (BCWP/ACWP).

Earned value (EV): The periodic, consistent, and objective measurement of work performed in terms of the budget planned for that work. The EV is synonymous with the BCWP and it is compared to the BCWS to obtain schedule performance and to the ACWP to obtain cost performance. 


\section{GLOSSARY (CONTINUED)}

Estimate at completion (EAC): Cost allocated to the work breakdown structure element to date, plus the estimate of costs for authorized work remaining. Authorized work remaining includes any undistributed budget.

Fiscal Year Spending Forecast (FYSF): The estimated total that will be spent from October through September (current Fiscal Year).

Funding carryover and new Budget Authorization (BA): This funding represents both the funding allocated to perform workscope planned in the prior fiscal year, not completed, and approved to be performed in the current fiscal year, as well as new BA to perform the approved baseline workscope.

Funding target: The level of funding that is anticipated (as a result of the Integrated Priority List process) in a given Fiscal Year based on an assumed funding level for the Site.

Multi-Year Work Plan - 10/1/XX: The Project's approved cost/schedule/technical baseline at the beginning of the fiscal year.

Progress Tracking System (PTS) - The standard reporting tool for the Office of Assistant Secretary for Environmental Management (EM). This system tracks program activities, accomplishments, and resources on a monthly basis to consistently measure program progress.

Schedule Performance Indicator (SPI): The SPI is the ratio of BCWP to BCWS, or (BCWP/BCWS).

Schedule variance (SV): The difference between BCWP and BCWS (SV $=$ BCWP - BCWS). At any time, or for a given period of time, it represents the difference between the planned dollar value of work actually accomplished and the value of the work scheduled to be accomplished.

Work breakdown structure (WBS): A product-oriented family tree division of real estate, hardware, software, services, and data products that organize, define, and display all of the work to be performed in accomplishing the program and/or project objectives. 


\section{ERC \\ Environmental Management Performance Report}

December 1999 


\section{TABLE OF CONTENTS}

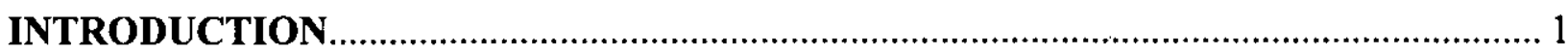

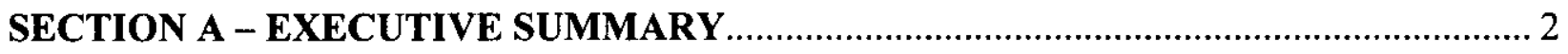

NOTABLE ACCOMPLISHMENTS.........................................................................2

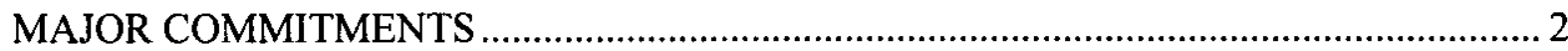

CRITICAL FEW PERFORMANCE MEASURES (PERFORMANCE INCENTIVES) ....... 4

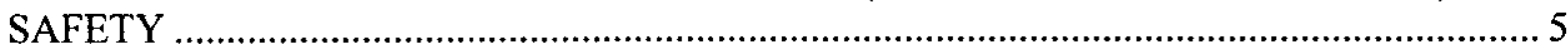

OVERALL COST/SCHEDULE PERFORMANCE ..................................................... 7

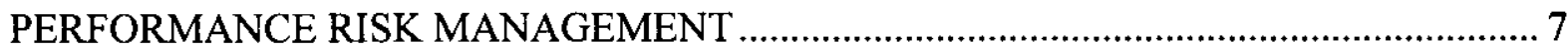

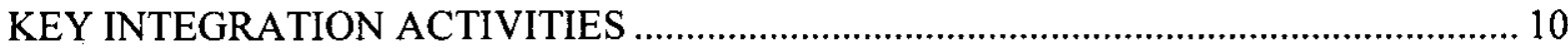

UPCOMING PLANNED KEY EVENTS ............................................................ 10

SECTION B - PROJECT PERFORMANCE SUMMARY ......................................... 11

REMEDIAL ACTION AND WASTE DISPOSAL PROJECT ....................................... 11

GROUNDWATER/VADOSE ZONE INTEGRATION PROJECT .............................. 12

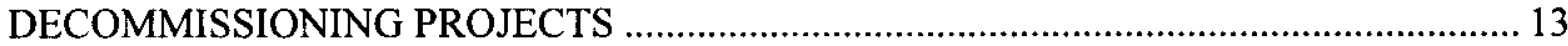

SURVEILLANCE/MAINTENANCE AND TRANSITION PROJECTS .......................... 14

PROGRAM MANAGEMENT AND SUPPORT ....................................................... 14

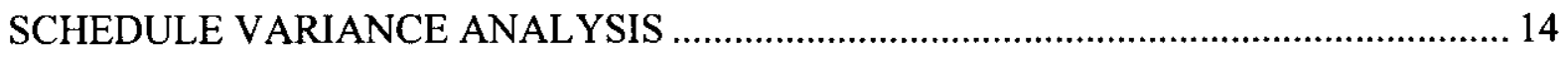

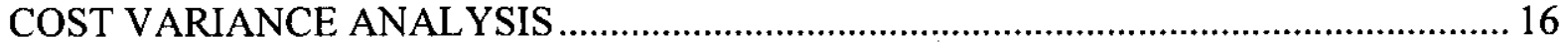

INTEGRATION WITH OTHER DOE HANFORD CONTRACTORS .............................. 18 


\section{INTRODUCTION}

The monthly Environmental Restoration Contract (ERC) Environmental Management Performance Report consists of two sections: Section A - Executive Summary, and Section B Project Performance Summary.

Section A provides an executive level summary of Bechtel Hanford, Inc.'s (BHI) performance information for the current reporting month and is intended to bring to Management's attention that information considered to be most noteworthy. The Executive Summary begins with a description of notable accomplishments that are considered to have made the greatest contribution toward safe, timely, and cost-effective cleanup. Following the accomplishments are summaries of major commitments that encompass Hanford Federal Facility Agreement and Consent Order (Tri-Party Agreement) milestones, along with waste site, assessments, facility completions, and tonnage status. Performance indicator status and safety statistics are also addressed. Fiscal year-to-date ERC Project cost and schedule variance analysis is summarized. Performance risk management information identifies major project issues that may be challenges in achieving cleanup progress. Opportunities are also identified that may assist in these challenges by using newly proven technologies. The Key Integration Activities section highlights site activities that cross contractor boundaries and demonstrate the shared value of working as a team to accomplish the work. The Executive Summary ends with a listing of major upcoming planned key events within a 90-day period.

Section B is a brief summary of the current month's activities for each of the ERC Projects. The five ERC subprojects consist of the Remedial Action and Waste Disposal Project, Groundwater/Vadose Zone (GW/VZ) Integration Project, Decommissioning Projects, Surveillance/Maintenance and Transition (SM\&T) Projects, and the Program Management and Support (PM\&S) Project. Further cost and schedule variance analysis is summarized for those Project Baseline Summaries (PBS) that are out of the standard thresholds. 


\section{SECTION A - EXECUTIVE SUMMARY}

\section{NOTABLE ACCOMPLISHMENTS}

Three Tri-Party Agreement milestones were completed during December, all ahead of schedule.

All soil remediation activities were completed at five waste sites in the $100 \mathrm{~B} / \mathrm{C}$ Area.

Soil remediation activities were initiated at the Landfill 1B waste site in the 300 Area.

All five groundwater pump and treat systems operated at or above the planned $90 \%$ availability levels through December.

Draft A of the Remedial Design Report and Remedial Action Work Plan (RDR/RAWP) for the In Situ REDOX Manipulation (ISRM) Project was transmitted to the regulators for review.

The Project Closeout Report for the 119-DR Exhaust Air Filter Sampling Building, 116-D, and 116-DR exhaust stack demolition was completed.

\section{MAJOR COMMITMENTS}

\section{Tri-Party Agreement Milestones}

Five Tri-Party Agreement milestones have been completed through December, all ahead of schedule. Three Tri-Party Agreement milestones were completed during December:

Regulator approval was received on December 9 for M-16-92B, Environmental Restoration Disposal Facility (ERDF) Cells \#3 and \#4 Ready to Accept Remediation Waste, due on December 31. The actual construction of the two new cells was completed six weeks ahead of schedule.

The Focused Feasibility Study (FFS) and Proposed Plan for the 100 Area Burial Grounds were transmitted to the regulators on December 21. This transmittal satisfies M-15-00A, Complete all Remaining 100 Area Operable Unit Pre-ROD Site Investigations Under Approved Work Plan Schedules, due on December 31.

The Draft A 200-CW-5 Remedial Investigation/Feasibility Study (RI/FS) Work Plan was transmitted to the U.S. Department of Energy (DOE), Richland Operations Office (RL) on December 14 for regulator review. This transmittal satisfies M-13-22, Submit U Pond/Z Ditches Cooling Water Group Work Plan, due on December 31. 


\section{Section A - Executive Summary}

\begin{tabular}{|l|c|}
\hline Total Tri-Party Agreement Milestones Due in FY00 & $\mathbf{1 8}$ \\
\hline Total Planned Through December & 5 \\
\hline Total Completed Through December & 5 \\
\hline
\end{tabular}

\begin{tabular}{|l|c|}
\hline Remaining Milestones to be Completed in FY00 & 13 \\
\hline Forecast Ahead of Schedule & 1 \\
\hline Forecast On Schedule & 9 \\
\hline Unrecoverable & 3 \\
\hline
\end{tabular}

\section{Performance Measures (Remediation and Facilities)}

Fiscal year 2000 (FY00) waste site excavation performance measures include a total of 29 waste sites. Excavation of one waste site was completed in December, for a total of four waste sites completed in FY00.

The Project Closeout Report for the demolition of the 119-DR Exhaust Air Filter Sampling Building, 116-D, and 116-DR exhaust stacks was completed in December. Demolition of both exhaust stacks and building was completed in August. The closure report constitutes completion of three facility closure performance measures during FY00.

\begin{tabular}{|l|c|c|c|c|}
\hline \multicolumn{1}{|c|}{ Performance Measures } & $\begin{array}{c}\text { DWP } \\
\text { FY00 }\end{array}$ & $\begin{array}{c}\text { Current } \\
\text { Baseline } \\
\text { (Incl. Baseline } \\
\text { Changes) }\end{array}$ & $\begin{array}{c}\text { Forecast } \\
\text { for FY00 }\end{array}$ & $\begin{array}{c}\text { Completed } \\
\text { YTD }\end{array}$ \\
\hline Waste Sites & 15 & 29 & 29 & 4 \\
\hline 100 Area Burial Ground Assessments & 0 & 45 & 45 & $45^{\mathrm{a}}$ \\
\hline 300-FF-2 Assessments & 76 & 76 & 76 & $76^{\mathrm{a}}$ \\
\hline Facilities & 0 & $4^{\mathrm{b}}$ & $4^{\mathrm{b}}$ & 3 \\
\hline Tons & $389 \mathrm{~K}$ & $549.5 \mathrm{~K}$ & $549.5 \mathrm{~K}$ & $150.8 \mathrm{~K}$ \\
\hline
\end{tabular}

Proposed Plan, Draft A submittal.

b116-D, 116-DR, 119-DR, and 108-F. 


\section{CRITICAL FEW PERFORMANCE MEASURES (PERFORMANCE INCENTIVES)}

All performance criteria are projected to meet Performance Incentive (PI) requirements. The EM-30 funding shortfall for the Canyon Disposition Initiative (CDI) will require scope adjustment. Workscope for the 233-S Plutonium Concentration Facility will be resequenced via a baseline change proposal (BCP) based on an approved Safety Evaluation Report (SER).

\begin{tabular}{|c|c|c|}
\hline Outcome & Performance Indicator & Status \\
\hline \multirow{3}{*}{$\begin{array}{l}\text { Restore the River } \\
\text { Corridor for Multiple } \\
\text { Uses }\end{array}$} & $\begin{array}{l}\text { 100/300 Area waste excavation, } \\
\text { disposal and backfill/regrade }\end{array}$ & $\begin{array}{l}\text { Baseline work projected to be completed per PI } \\
\text { requirements, } 40 \% \text { of stretch commenced and projected to } \\
\text { be completed per PI requirements. }\end{array}$ \\
\hline & $\begin{array}{l}\text { Reactor ISS and preparation of } \\
\text { facilities for decommissioning }\end{array}$ & $\begin{array}{l}\text { Baseline reactor ISS work projected to be completed per PI } \\
\text { requirements, KE/KW legacy waste removal behind } \\
\text { schedule due to additional regulatory requirements; no } \\
\text { stretch or superstretch commenced. }\end{array}$ \\
\hline & $\begin{array}{l}\text { Manage groundwater plumes per } \\
\text { interim RODs }\end{array}$ & $\begin{array}{l}\text { Baseline work projected to be completed per PI } \\
\text { requirements, ISRM drilling behind schedule due to late } \\
\text { signing of 100-HR-3 ROD amendment; no stretch or } \\
\text { superstretch commenced. }\end{array}$ \\
\hline \multirow{6}{*}{$\begin{array}{l}\text { Transition Central } \\
\text { Plateau } \\
\text { to Support Long-Term } \\
\text { Waste Management }\end{array}$} & \multirow{3}{*}{ Maintain facilities until D\&D } & $\begin{array}{l}\text { 233-S baseline work behind schedule due to process hood } \\
\text { USQ recovery and SER. Recovery schedule implemented; } \\
\text { FY00 work will be resequenced via BCP upon approval of } \\
\text { SER. }\end{array}$ \\
\hline & & $\begin{array}{l}\text { 224-B baseline work impacted by inoperable B Plant } \\
\text { exhaust system. Project will be rebaselined via BCP upon } \\
\text { B Plant exhaust system restart. }\end{array}$ \\
\hline & & $\begin{array}{l}\text { CDI baseline work projected to be completed per PI } \\
\text { requirements; EM-30 funding shortfalls will require scope } \\
\text { adjustment; no stretch work commenced. }\end{array}$ \\
\hline & $\begin{array}{l}\text { Complete System Assessment } \\
\text { Capability }\end{array}$ & $\begin{array}{l}\text { Baseline work projected to be completed per PI } \\
\text { requirements. }\end{array}$ \\
\hline & Soil sites addressed & $\begin{array}{l}\text { Baseline work projected to be completed per PI } \\
\text { requirements. }\end{array}$ \\
\hline & $\begin{array}{l}\text { Manage groundwater plumes per } \\
\text { interim RODs }\end{array}$ & $\begin{array}{l}\text { Baseline work projected to be completed per PI } \\
\text { requirements; no stretch or superstretch work commenced. }\end{array}$ \\
\hline Multiple & Comprehensive performance & $\begin{array}{l}\text { No safety, conduct of operations, environmental or } \\
\text { teaming issues identified per PI requirements; all baseline } \\
\text { work projected to be completed per PI requirements. }\end{array}$ \\
\hline
\end{tabular}




\section{SAFETY}

\begin{tabular}{|l|c|c|}
\hline \multicolumn{1}{|c|}{ Type } & Fiscal Year to Date & December \\
\hline First Aid & 27 & 10 \\
\hline Lost/Restricted Workcase & 1 & 0 \\
\hline OSHA Recordable & 4 & 1 \\
\hline
\end{tabular}

ERC has worked 408,600 hours since the last lost workday case (as of January 21).

The ERC Integrated Safety Management System (ISMS) Phase I and II Verification Plan has been issued to verification support personnel. ISMS management and labor briefings have begun. Daily ERC team awareness activities are ongoing. A Verification Review is scheduled for March 2 through March 17.

\section{ERC First Aid Case Rate Per 200,000 Hours}

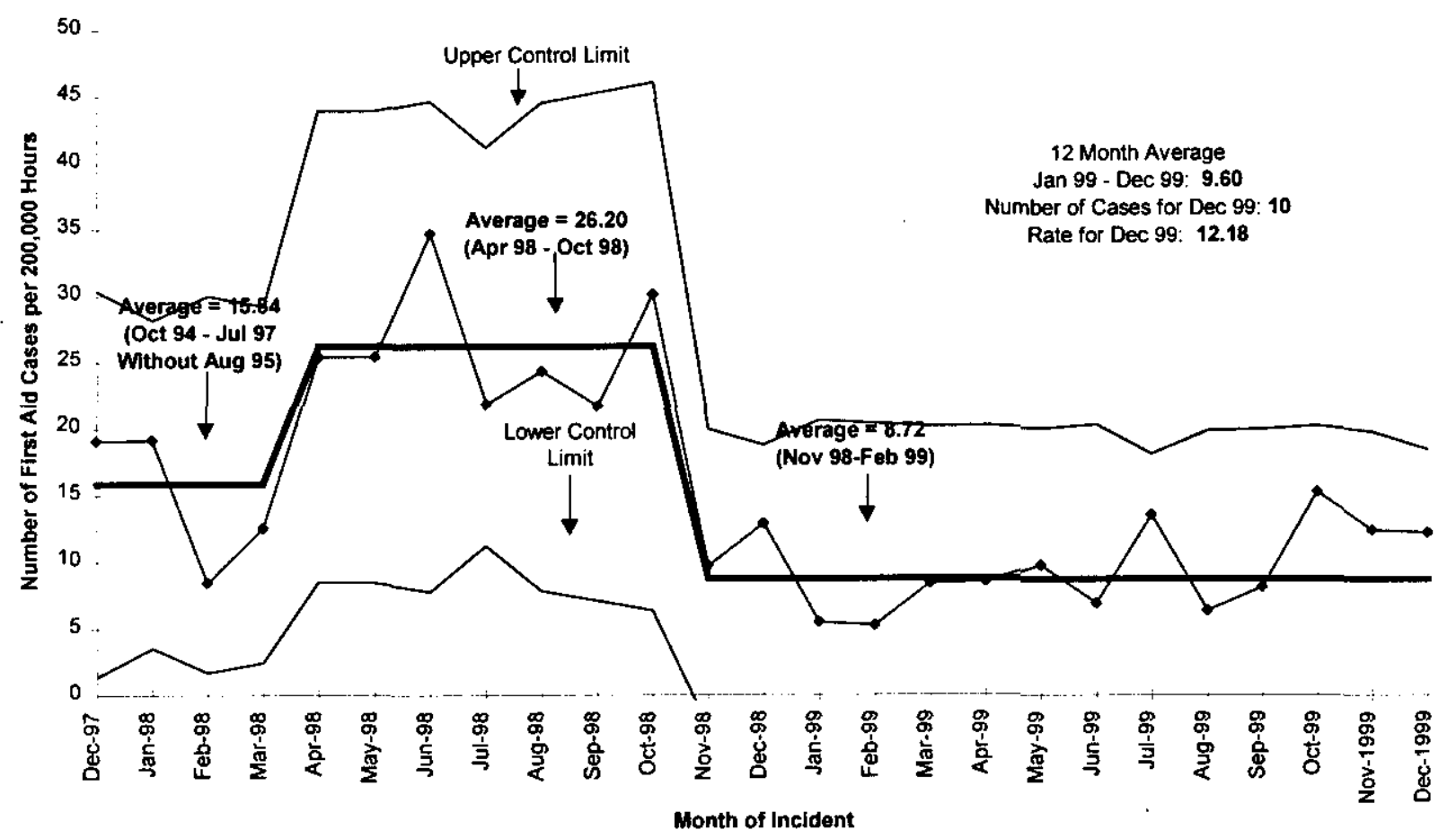




\section{ERC Recordable Case Rate Per 200,000 Hours}

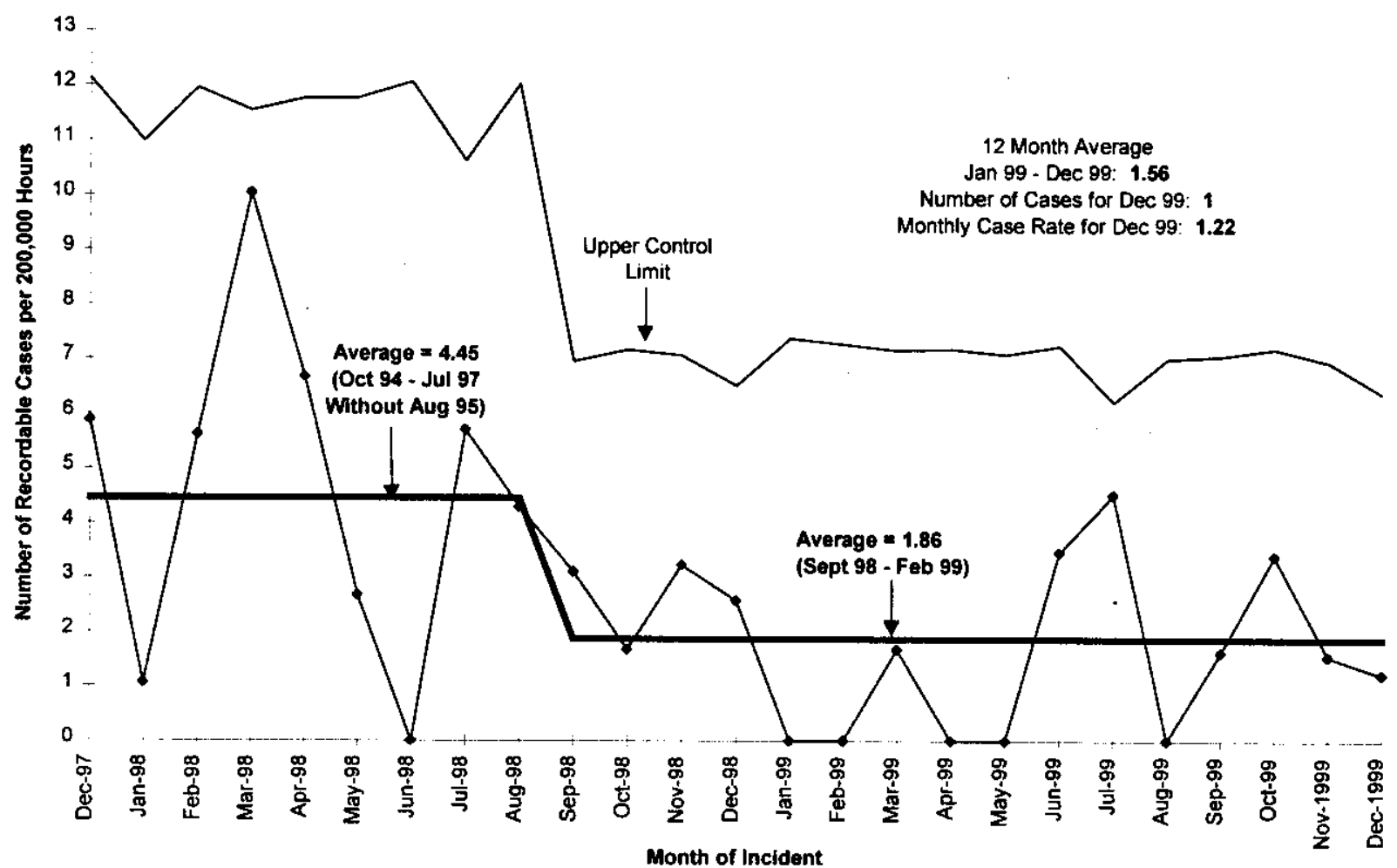

\section{ERC Lost/Restricted Workday Case Rate Per 200,000 Hours}

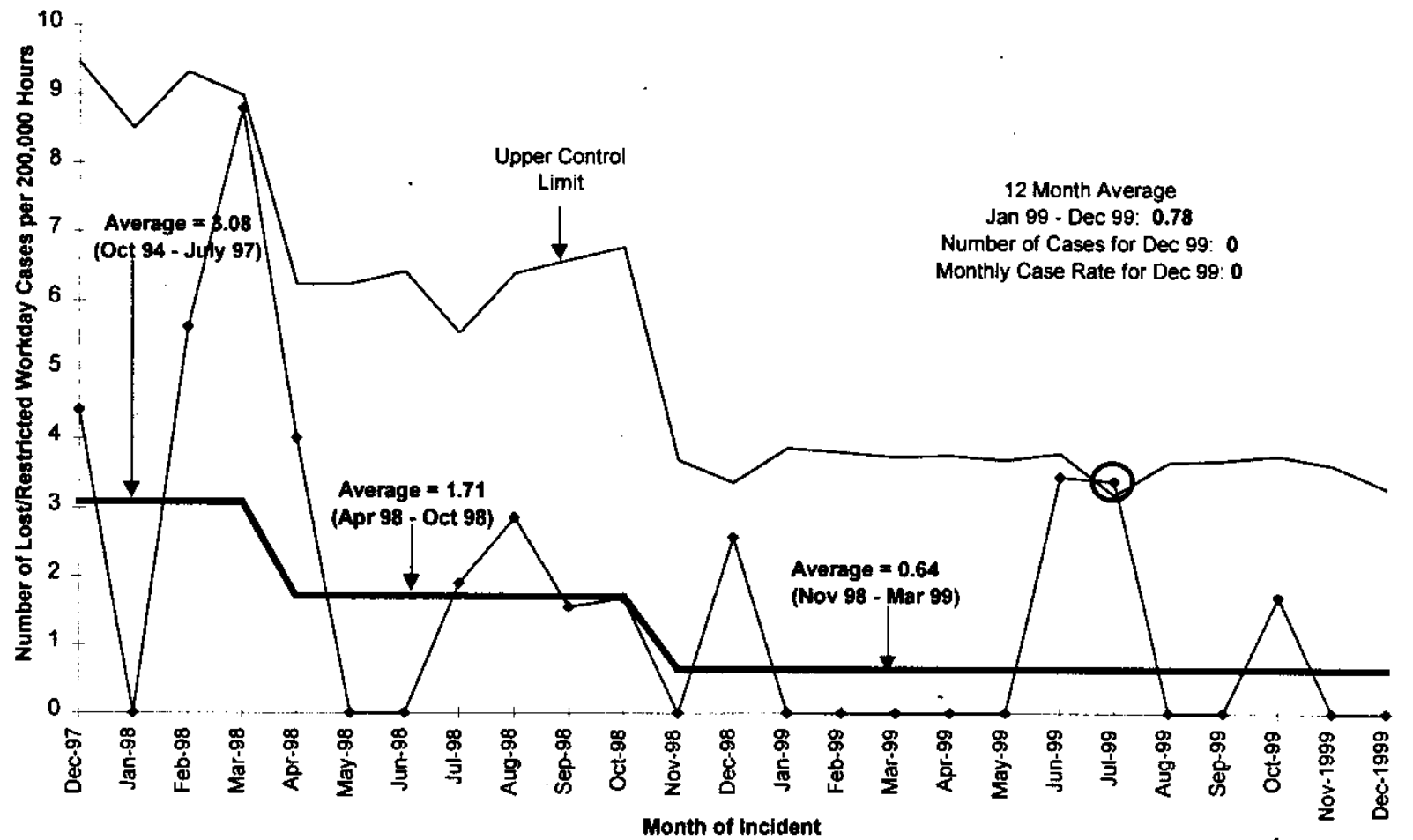




\section{OVERALL COST/SCHEDULE PERFORMANCE}

\section{Cost Variance}

At the end of December, the ER Project had performed $\$ 29.9 \mathrm{M}$ worth of work, at a cost of $\$ 25.7 \mathrm{M}$. This accounts for a favorable cost variance of $\$ 4.2 \mathrm{M}(14.2 \%)$. The positive cost variance is attributed to FY99 year-end accrual reversals, site excavation savings, borehole drilling and test pit trenching costs less than planned (due to efficiencies), and Interim Safe Storage (ISS) labor costs less than planned.

\section{Schedule Variance}

The ER Project is $\$ 5.4 \mathrm{M}(-15.3 \%)$ behind schedule for December. The negative schedule variance is attributed to delays in the $100 \mathrm{D}$ Area small sites' verification sampling (resulting from additional plumes), mobilization at $100 \mathrm{~F}$ Area (due to plume growth at $\mathrm{H}$ Area), $100 \mathrm{H}$ pipeline removal, GW/VZ System Assessment Capability (SAC) Rev. 0 documentation and Science and Technology (S\&T) activities, the start of ISRM field work, and late billings for sitewide assessments.

\section{PERFORMANCE RISK MANAGEMENT}

\section{Issues/Early Warnings}

- Notice of Violation (NOV): Issued to RL on November 17 for waste management violation for failure to have a Waste Control Plan and failure to sample waste container (tributyl phosphate) per approved sampling and analysis plan.

Status: Response letters addressing the NOVs and identifying completed corrective actions, actions with due dates still to be completed, and ongoing actions were submitted to RL on December 14 for transmittal to the regulatory agencies: No response has been received to date. A Tri-Party Agreement dispute was filed by RL on November 24 and withdrawn on December 30.

- Notice of Penalty: Issued to BHI and RL on November 17 for failure to characterize waste prior to disposal.

Status: A corrective action plan was submitted on December 1. A Tri-Party Agreement dispute was filed by RL on November 24 and is still pending. An application for relief from penalty was requested on December 1. The Washington State Department of Ecology (Ecology) denied application on January 12. RL and BHI are pursuing a settlement agreement. 
- Resource Conservation and Recovery Act (RCRA) Compliance Well Funding: Capital funds for groundwater monitoring well installation will be expended in meeting the calendar year 1999 milestones that are due in February 2000. No funds are currently available for outyears. This will impact Tri-Party Agreement Milestone M-24-00 for calendar year 2000 and beyond.

Status: $\mathrm{RL}$ is working across all applicable Hanford Site programs to identify funding for a new well strategy in calendar year 2000. Funding sources for each facility are under review.

- Budgets Do Not Support Compliance Milestones: The President's budget of $\$ 140.6 \mathrm{M}$ (including additional ISS funding) for FY00, and the budget submittal of $\$ 138.3 \mathrm{M}$ for FY01, do not support completion of all of the Tri-Party Agreement compliance milestones.

Status: $R L$ is continuing to evaluate funding priorities and options. The ER Project, as part of the Detailed Work Plan (DWP) process, has planned FY00, FY01, and FY02 at $\$ 135.1 \mathrm{M}$ (excluding ISS funding), $\$ 163.7 \mathrm{M}$, and $\$ 164.0 \mathrm{M}$, respectively.

- 100-B/C Pipelines: FY00 and FY01 funding not available to start work on B/C pipeline remediation. The regulators have not been willing to renegotiate the Tri-Party Agreement milestone date of February 28, 2001. Forecast under review based on funding determination for FY01 and FY02.

Status: RL continues to discuss alternatives with the regulators.

- 100-N Cribs: The Auditable Safety Analysis/Final Hazard Classification (ASA/FHC) to support remediation of the 100-N cribs was submitted to RL on November 29. Comments were due December 30, and received on January 11, 2000. The comments received rescind prior agreements. Previous technical direction received on October 22, 1996 accepted 10 rem at 300 meters ( 984 feet) as basis for nuclear FHC and agreements on dose scenarios. Changes to these agreements will require rework of the ASA document, which will delay remedial action subcontractor start and significantly impact cost and schedule. In addition, failure to start remediation in July 2000 would not comply with stipulated permit conditions that can result in fines, penalties, and civil/criminal actions. Approval of this document is scheduled for early February.

Status: BHI/RL will continue to meet to resolve this issue. (Note: The Request for Proposal [RPF] for remediation was issued to 15 potential bidders; 10 have committed to bid, with award scheduled for March 17, 2000.)

- FY01 ISS Funding: No funding in the Project Priority List/Integrated Priority List (PPL/IPL) for Reactor ISS in FY01 and FY02, which will result in program suspension and loss of potential cost savings.

Status: Need strategy to maintain critical resources and visible progress. 
- CDI Funding: EM-30 has informally notified the project that they will not be funding the CDI per the DWP assumption in FY00 $(\$ 400 \mathrm{~K})$.

Status: RL is in the process of providing the project with formal notification from EM-30. $\mathrm{A} B C P$ to defer $\mathrm{CDI}$ scope will be submitted upon receipt of formal notification. There is no funding planned in the PPL/IPL for FY01 and FY02.

- 200-UP-1 and 200-ZP-2: Regulatory agencies desire continued operation of 200-UP-1 and 200-ZP-2 Operable Units (not included in DWP).

Status: (A) 200-UP-1: A concurrence letter to Ecology is being drafted that will allow for a one-year shutdown to monitor contaminant rebound effects. (B) 200-ZP-2: Unit not scheduled for restart. The U.S. Environmental Protection Agency (EPA) is adamant on continued operations of one or more soil vapor extraction systems beginning April 1. Currently, $R L$ is actively pursuing additional funds within the Hanford complex to support continued operations. If this is not attainable, RL must provide direction for work operations to continue. Upon receipt, BHI/RL management will evaluate work scope tradeoffs and submit appropriate change control. A decision (scope and funding) for continued operations is required by $R L$ management on or before March 1, 2000.

- 200 Area RI/FS: Approximately 700 soil contaminated sites (200 Area) grouped into 23 process-based operable units are to be characterized by 2008 and remediated by 2018 . Currently, no out-year funding exists beginning in FY01. Long-term, RL must decide its budgetary position toward assessment and cleanup of the 200 Area liquid sites. The regulator position is to submit Tri-Party Agreement change packages for each operable unit work plan for enforceability in completing the RI through Record of Decision (ROD) based on existing Tri-Party Agreement milestones.

Status: RL has prepared a Tri-Party Agreement change package for the 200-CW-1 Operable Unit containing RI/FS milestones for FY00 only. In addition, RL is currently working on a long-term strategy for prioritizing the 200 Area assessment and remediation activities in conjunction with other site cleanup decisions.

\section{Opportunities}

Waste Minimization: Existing information pertaining to the 126-F-1 ash pits indicates that the site was contaminated due to a previous effluent leak. Preliminary analysis shows that the south portion (approximately $163 \mathrm{~K}$ metric tons [ $180 \mathrm{~K}$ tons]) of the site may be clean, resulting in a potential cost savings. Discussions with EPA have proven favorable on this approach. ER will continue to pursue clean closure of the site.

River Corridor Initiative (Complete remediation of 155 square kilometers [60 square miles], including Hanford townsite): This initiative is currently identified as a superstretch item with an approximate value of $\$ 5.0 \mathrm{M}$. High-visibility public access opportunities; also a superstretch item (bike trail, road to B Reactor, and boat ramp at Hanford townsite). A feasibility plan is scheduled to be completed on February 15. 


\section{Section A - Executive Summary}

Accelerate the ISS (four reactors for the price of three by 2003): Currently completing the "to go" estimate based on progress to date and supplemental funding received for FY00.

Forecast for estimate completion is February 15.

\section{KEY INTEGRATION ACTIVITIES}

- Groundwater/Vadose Zone Integration Project

BHI/Office of River Protection (ORP)/Pacific Northwest National Laboratory (PNNL)/Regulators/Public

Multi-contractor team implementing an integrated site strategy for assessment of groundwater pathways.

\section{UPCOMING PLANNED KEY EVENTS}

- Install RCRA groundwater monitoring wells at rate of up to 50 in calendar year, if required (M-24-00K, M-24-41, M-24-42, M-24-43, M-24-44, and M-24-45 all due February 29).

- Complete remediation and backfill of 19 waste sites in the 100-BC-1 and 100-BC-2 Operable Units (M-16-08B due March 31).

- Obtain regulator approval for Tri-Party Agreement Change Package rebaselining M-16-13A, Initiate Remedial Action for 100-FR-1 Operable Unit, from January 31, 2000 to March 2, 2001 . 


\section{SECTION B - PROJECT PERFORMANCE SUMMARY}

\section{REMEDIAL ACTION AND WASTE DISPOSAL PROJECT}

Substantial progress was made in all areas of ER Project activities during December.

Remediation work proceeded at the $100 \mathrm{~B} / \mathrm{C}, \mathrm{D}, \mathrm{F}, \mathrm{H}$, and 300 Areas. Revegetation of the 116-B-1, -11, -13, -14, and 116-C-5 waste sites was completed during the week of December 6 . This activity marks the completion of remedial actions for the high priority, near-river (Group 1) waste sites in the $100 \mathrm{~B} / \mathrm{C}$ Area.

Closeout/verification sampling of completed excavation areas continued at the D Area remediation site. Excavation activities for the Group 3 small waste sites progressed in December, including plumes found during planned remediation activities.

Remediation efforts also proceeded at several $\mathrm{H}$ Area waste sites, including excavation of the baseline quantities at the 116-H-1 Disposal Trench. When higher than expected contamination levels were encountered at the 116- $\mathrm{H}-7$ Retention Basin, excavation was temporarily moved to another waste site until the radiological work permit and control boundaries were revised. Approximately $90 \%$ of the 116-H-7 baseline excavation has been completed. At month's end, overburden removal of the 1.5-meter (60-inch) diameter pipeline north of the 116-H-7 Retention Basin was $75 \%$ complete. This area is the deepest pipeline excavation in the $100 \mathrm{H}$ Area ( 8 meters [ 26 feet]). Further remediation will be required at all three of these sites, due to additional plume growth. Variance sample results from the 1607-H-2 and 1607-H-4 Septic Drain Field waste sites indicated elevated arsenic levels. Closeout sampling has been delayed until a strategy is developed to address the arsenic presence. The elevated arsenic levels appear to be a result of historical agricultural practices prior to the establishment of the Hanford Site.

The draft 100 Area Burial Grounds FFS and Proposed Plan were transmitted to the regulators on December 21. This transmittal satisfies the Tri-Party Agreement Milestone M-15-00A that was due on December 31. These documents identify the preferred alternative of remove, treat, and dispose for the 45 burial grounds in the 100 Areas.

The RFP for remediation of the 100-NR-1 cribs was issued on December 6. Subcontract award is anticipated in March. The NR-1 ROD authorizing this remediation is scheduled for signing on January 19. The ASA/FHC is undergoing technical reviews, and is expected to be approved in February.

Remediation efforts progressed in the 300 Area. Remediation activities were initiated at Landfill 1B. Work was also initiated on relocation of the sanitary sewer line at the South Process Pond. This work was competitively bid, which yielded considerable savings. The relocation is expected to be complete by January 14, which will allow resumption of remediation in the west embankment of the South Process Pond. The remediation workscope at the South Process Pond has been greatly hampered by high winds. Several days of waste loading operations have been lost since the beginning of FY00. The schedule is expected to be recovered in January. 
The regulators approved Revision 2 of the ERDF Leachate Management Plan on December 9. The first production transfer of leachate to the Effluent Treatment Facility (ETF) via the new pipeline link was accomplished on December 28. During December, shipments totaling 47,241 metric tons $(52,075$ tons) of contaminated waste were transported to the ERDF from all ER Project sources. 136,774 metric tons ( 150,768 tons) have been received in FY00. To date, $1,863,375$ metric tons $(2,054,443$ tons) of material have been received and placed in the disposal facility.

On December 9, the regulators completed their review of the Construction Quality Assurance Reports associated with the ERDF Cells \#3 and \#4 expansion. The regulators agreed the construction met requirements, and approved the additional cells for operation. This operational readiness approval satisfies Tri-Party Agreement Milestone M-16-92B, which was due on December 31. Construction of the two new cells began in September 1998, and was completed about six weeks ahead of schedule. Expansion of the ERDF required excavation of 1.4 million cubic meters ( 1.8 million cubic yards) of soil in the 200 West Area. The two combined cells measure 305 meters ( 1,000 feet) long, 153 meters ( 500 feet) wide, and 21 meters ( 70 feet) deep, and consist of multiple safety barriers that form a primary and secondary protection system. The liner system is designed to prevent migration of contaminants to the soil and groundwater. The new cells will be dedicated early in 2000 , and will begin receiving waste in the spring.

FY00 waste site performance measures include a total of 29 sites. Excavation of one waste site was completed in December, for a total of four waste sites in FY00.

FY00 assessment performance measures include a total of 121 assessments. 76 assessments involve the cleanup strategy at the 300-FF-2 Operable Unit sites. - An additional 45 assessments were deferred from FY99, and are being incorporated in the Proposed Plan (leading to a ROD) for the 100 Area Burial Grounds.

\section{GROUNDWATER/VADOSE ZONE INTEGRATION PROJECT}

The GW/VZ Integration Project completed the internal review of the draft software requirements specification (Identify System Assessment Capability [SAC] Rev. O Requirements). This product is the first, and key, section of the Assessment Design Document for the SAC, Rev. 0. The requirements specification includes detailed requirements for each component of the SAC. Comments that were received from DOE, Headquarters (HQ) and Congressional staff reviews were incorporated into the draft Semi-Annual Report. The document will be completed in January. The Sample Distribution Plan for S\&T Borehole B8812 was completed. This plan supports distribution of uncontaminated core material to the Environmental Management Science Program (EMSP).

Draft A versions of the ISRM RDR/RAWP were transmitted to the regulators for review. These documents contain an ISRM well installation description of work, and a data quality objective (DQO) summary. Well drilling is expected to begin in January. 
FY00 and carryover FY99 well maintenance activities continued in December. Five out of eight wells were drilled, and casing installation was completed. The remaining three wells are forecast for completion by the end of January.

During December, three reports were completed by the GW/VZ Integration Project that address long-term groundwater monitoring characterization, analysis, and possible monitoring alternatives (including vadose monitoring techniques).

All groundwater pump and treat systems operated above planned $90 \%$ availability levels through December, with the exception of ZP-1, which operated near the lower planned availability limit. Since system inception, the five pump and treat systems have processed over 3.4 billion liters of groundwater, removing 3,605 kilogram of carbon tetrachloride, 150 kilogram of chromium, and 0.746 curies of strontium. Approximately 236 million liters of groundwater have been processed in FY00, removing approximately 201 kilogram of carbon tetrachloride, 17.3 kilogram of chromium, and 0.041 curies of strontium. All pump and treat systems were placed on standby in late December to ensure no freezing problems would occur from potential Y2K issues. All systems are expected to be restarted in January.

The Draft B RI/FS Work Plan for the 200-CS-1 Chemical Sewer Waste Group was completed for public review. The public review began on December 12, and is scheduled for completion on January 14.

The Draft A 200-CW-5 RI/FS Work Plan, which addresses remedial actions at the 200 Area 200-CW-5 U Pond and Z Ditches Cooling Water Waste Group, was issued on December 14 for regulator review. This transmittal satisfies Tri-Party Agreement Milestone M-13-22, which was due on December 31.

\section{DECOMMISSIONING PROJECTS}

Substantial progress was made at the F and DR Reactor ISS projects during December. The F Reactor fan room slab demolition and debris loadout were completed, and demolition and debris loadout activities were initiated at the F East Reactor slabs and tunnels. The DR Reactor valve pit demolition and debris loadout were also completed. Phase III field sampling at the $F$ and DR Reactor underground structures were initiated in mid-December.

The Project Closeout Report for the demolition of the 119-DR Exhaust Air Filter Sampling Building, 116-D, and 116-DR exhaust stacks was completed in December. Demolition of both exhaust stacks and building was completed in August. The closure report constitutes completion of three facility closure performance measures during FY00.

Other December decommissioning activities included the completion of the historical review of the 224-B Plutonium Concentration Facility, and the completion of the B Reactor Museum Phase II Feasibility Study subcontract bid package. This bid package supports the completion of Tri-Party Agreement Milestone M-93-05, which is due on June 30. 
Steady progress continued on the loadout hood dismantlement in the 233-S Plutonium Concentration Facility. $90 \%$ of the frame has been removed, leaving only the sump areas for removal. Electrical work was also performed. Field sketches were completed, and weather enclosure and glovebags were ordered for supply/exhaust duct removal. Support activities continued in resolving the process hood safety evaluation comments. All Decontamination and Decommissioning (D\&D) activities within the $233-S$ Facility continue to be accomplished in a safe manner. Within the last 27 months, there have been no skin or clothing contamination incidents. This safety record is particularly noteworthy when considering the high radiation levels of the facility and work locations, and that an average of over 170 personnel entries are made into contaminated areas each month.

\section{SURVEILLANCE/MAINTENANCE AND TRANSITION PROJECTS}

Surveillance and maintenance (S\&M) activities proceeded in December to ensure inactive facility integrity and safety. The work package was completed for the removal of legacy waste from H Reactor area. The H, KE, and KW Reactors' annual surveillance and housekeeping activities were completed. The safety evaluation for planned stabilization activities in the Reduction Oxidation (REDOX) Facility plutonium loadout hood was also completed.

\section{PROGRAM MANAGEMENT AND SUPPORT}

The ERC was recognized in the Congressional News Briefing Sheet for the successful rock crusher transfer from the Hanford Site to the Ohio Mound Site in November. This waste minimization effort resulted in a savings to the Ohio Field Office of $\$ 750 \mathrm{~K}$, by eliminating the need to purchase the equipment. In utilizing this crusher, DOE estimates a savings between $\$ 4$ to $\$ 12 \mathrm{M}$ over the next three years.

The FY00 Baseline Update and Reconciliation change proposal was completed and forwarded to HQ for approval. The revised baseline identifies a \$1.77B increase to overall Hanford Site restoration costs. These costs are primarily due to transuranic waste quantity and escalation increases. The lifecycle ER schedule was also extended from FY44 to FY46 to accommodate site stewardship planning assumptions.

\section{SCHEDULE VARIANCE ANALYSIS}

\section{ER01 - 100 Area ER Remedial Action (-13.5\%/\$-887K)}

Cause: Negative schedule variance attributed to limited subcontractor resources for 100-HR-1 pipeline removal, and continued plume growth at 100-DR and 100-H Areas.

Impact: None. 
Corrective Action: HR-1 pipeline subcontractor has added more resources and has implemented a recovery schedule; baseline and remediation schedules will be revised via change control to reflect plume growth.

ER02 - 200 Area ER Remedial Action (10.9\%/\$220K)

Cause: Positive schedule variance attributed to test pit trenching and sampling completed ahead of schedule due to efficiencies, borehole drilling and sampling ahead of schedule.

Impact: None.

Corrective Action: None.

ER03 - 300 Area ER Remedial Action (-16.5\%/\$-310K)

Cause: Negative schedule variance attributed to delays in water line tie-ins pending incorporation of a new procedure, deferred sewer line contract award to optimize contractor pricing, deferred Landfill 1A remediation in order to remediate Landfill $1 \mathrm{~B}$ and South Process Pond first.

Impact: None, not on critical path for project completion.

Corrective Action: None.

\section{ER06 - ER Decontamination and Decommissioning (-12\%/\$-463K)}

Cause: Negative schedule variance attributed to delays in 233-S loadout hood dismantlement activities caused by deteriorated glovebag removal, roof duct removal difficulties, and extended approval of SER addressing process hood activities.

Impact: None at this time.

Corrective Action: Recovery schedule implemented on loadout hood with removal scheduled for January 2000. Process hood SER signed January 21, 2000; characterization activities initiated.

\section{ER08 - Groundwater Management Project (-21.4\%/\$-131K)}

Cause: Negative schedule variance attributed to delays of the ISRM ROD Amendment approval and RDR/RAWP resulting in late start of field work, analyzer replacement and system calibration for groundwater management unit 200-ZP-1 delayed due to equipment availability problems, and deferred groundwater well maintenance.

Impact: None. 
Corrective Action: ISRM contract awarded January 21 ; project schedule adjusted via change control for approximately 30 -day ROD delay. Recovery schedules have been implemented for maintenance activities.

\section{ER10 - ER Program Management and Support (-31.3\%/\$-1,327K)}

Cause: Negative schedule variance attributed to late billing of site-wide assessments.

Impact: None.

Corrective Action: None.

VZ01 - Site-wide GW/VZ Integration Project (-31.5\%/\$-800K)

Cause: Negative schedule variance attributed to $\mathrm{SAC}$ (Rev. 0 ) requirements development took longer than planned, which impacted initiation of Design Specification, Test Plan, and Planned Analysis development; deferred S\&T Plan due to resource availability; and reduced staff availability during Christmas/New Year holidays causing logic diagram and planning delays.

Impact: None.

Corrective Action: SAC recovery schedule has been implemented with full recovery expected in February-March; additional S\&T resources have been dedicated to completing the roadmap, now scheduled for April; policy work group meeting has been deferred to April with no impact expected to completion schedule.

\section{COST VARIANCE ANALYSIS}

\section{ER01 - 100 Area ER Remedial Action (17.5\%/\$991K)}

Cause: Positive cost variance attributed to costs lower than planned for 100-DR small sites excavation and sampling, and 100-FR-1 site prep work.

Impact: Cost underrun.

Corrective Action: Savings will be used for other environmental restoration work.

\section{ER02 - 200 Area ER Remedial Action (33.1\%/\$742K)}

Cause: Positive cost variance attributed to test pit trenching efficiencies and fewer samples required than originally planned, borehole drilling costs less due to utilizing RCRA groundwater borehole.

Impact: Cost underrun.

Corrective Action: Savings will be used for other environmental restoration work. 


\section{ER03 - 300 Area ER Remedial Action (44.1\%/\$691K)}

Cause: Positive cost variance attributed to management and administrative cost efficiencies, and under accrual in South Process Pond work.

Impact: Cost underrun.

Corrective Action: Savings will be used for other environmental restoration work.

\section{ER04 - ER Waste Disposal (18.6\%/\$903K)}

Cause: Positive cost variance attributed to FY99 accrual reversal.

Impact: None.

Corrective Action: None.

\section{ER06 - ER Decontamination and Decommissioning (10.9\%/\$370K)}

Cause: Positive cost variance attributed to costs less than planned for ISS equipment usage and procurements, $105-\mathrm{F}$ valve pit pipe and equipment removal, 224-B Engineering Evaluation/Cost Analysis (EE/CA) document development, and fewer resources required for ISS.

Impact: Cost underrun.

Corrective Action: Savings will be used for other environmental restoration work.

ER07 - ER Long-term Surveillance and Maintenance (300\%/\$3K)

Cause: Insignificant: (BCWP: 1; ACWP: -2).

Impact: None.

Corrective Action: None. 


\section{INTEGRATION WITH OTHER DOE HANFORD CONTRACTORS}

- GW/VZ Integration Project

BHI/ORP/PNNL/Regulators/Public

Multi-contractor team implementing an integrated site strategy for assessment of groundwater pathways.

- K Basin Waste Disposal

BHI/Fluor Hanford, Inc. (FHI)

A Memorandum of Understanding has been signed between BHI/FHI for the packaging, treatment, transport, and disposal of $\mathrm{K}$ Basin waste to ERDF.

- 300 Area Waste Disposal

\section{BHI/PNNL}

A Letter of Instruction and work order from PNNL to BHI was signed on January 4 for the transport and disposal of waste from the 331-A Building demolition. Transportation and disposal of the estimated 304 metric tons ( 336 tons) of building debris is expected to begin in late January. 


\section{PNNL \\ Environmental Management Performance Report}

Monthly Report - December 1999

February 2000

PREPARED FOR THE U.S. DEPARTMENT OF ENERGY, RICHLAND OPERATIONS OFFICE OFFICE OF ENVIRONMENTAL MANAGEMENT

Pacific Northwest National Laboratory

Operated for the U.S. Department of Energy by Battelle Memorial Institute 


\section{Table of Contents}

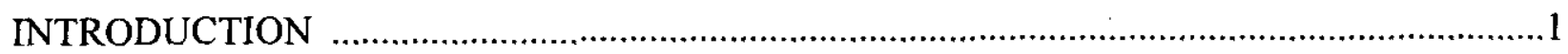

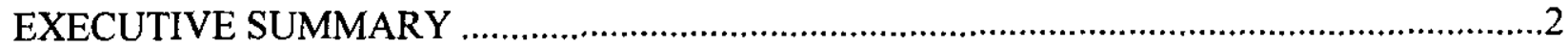

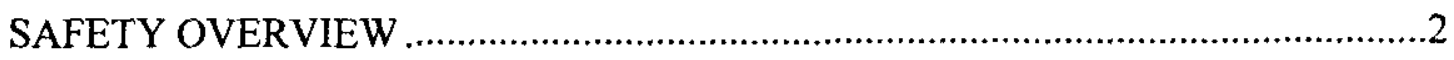

COST/SCHEDULE PERFORMANCE STOPLIGHT ........................................

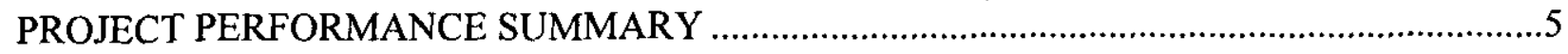

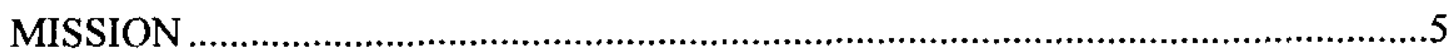

PERFORMANCE DATA AND ANALYSIS ................................................ 
The purpose of this monthly report is to provide the Department of Energy Richland Operations Office (DOE-RL) a report of the Pacific Northwest National Laboratory (PNNL) performance by Battelle Memorial Institute and its subcontractors.

Section A, Executive Summary, begins with the safety metrics status for all PNNL activities via graphics followed by senior management's overall performance assessment of all EM activities conducted at PNNL via a stoplight chart.

Section B, Project Performance Summary, provides a brief summary of the month's performance for the PNNL lead activity, PNNL Waste Management (PBS RL-ST01). Summary analyses pertaining to PNNL's support to other PBS's are addressed in the contractor's report having lead responsibility for that scope.

The "as of" dates for information are shown in the various sections as noted. If no date is shown the information is current as of December 26th. 


\section{PNNL Environmental Management Performance Report - hec 4.40 Section A - Executive Summary}

This section provides an executive level summary of performance information and is intended to bring to Management's attention that information considered to be most noteworthy. The section begins with overviews of safety followed by a stoplight chart on overall performance.

\section{Safety Overview}

$T^{\mathrm{n}}$ he focus of this section is to document trends in work related injuries and illnesses. Improvements in these rates are due to the efforts of the PNNL workforce as they implement the Integrated ES\&H Management System (ISMS), work towards achieving Voluntary Protection Program (VPP) "star" status, and accomplish work through Enhanced Work Planning (EWP). Safety and health statistical data is presented in this section.

\section{Significant Safety and Health Events}

The PNNL OSHA Recordable Rate has been below the average for eight of the past nine months. Case reclassifications have removed the previously noted significant decrease in the lost and restricted workday case rate. However, the past seven months of data have been below average, indicating a significant decrease. The recordable and lost workday case rates have now been below the 2.22 and 0.98 averages respectively for the seventh month in a row. Due to the impending changes, potential average changes have been noted on the associated graphs. PNNL also experienced a notable change in the July 1999 severity rate, which pushed it slightly above the upper control limit. This change was due to the accumulation of additional lost workdays on an ongoing, July 1999 case.

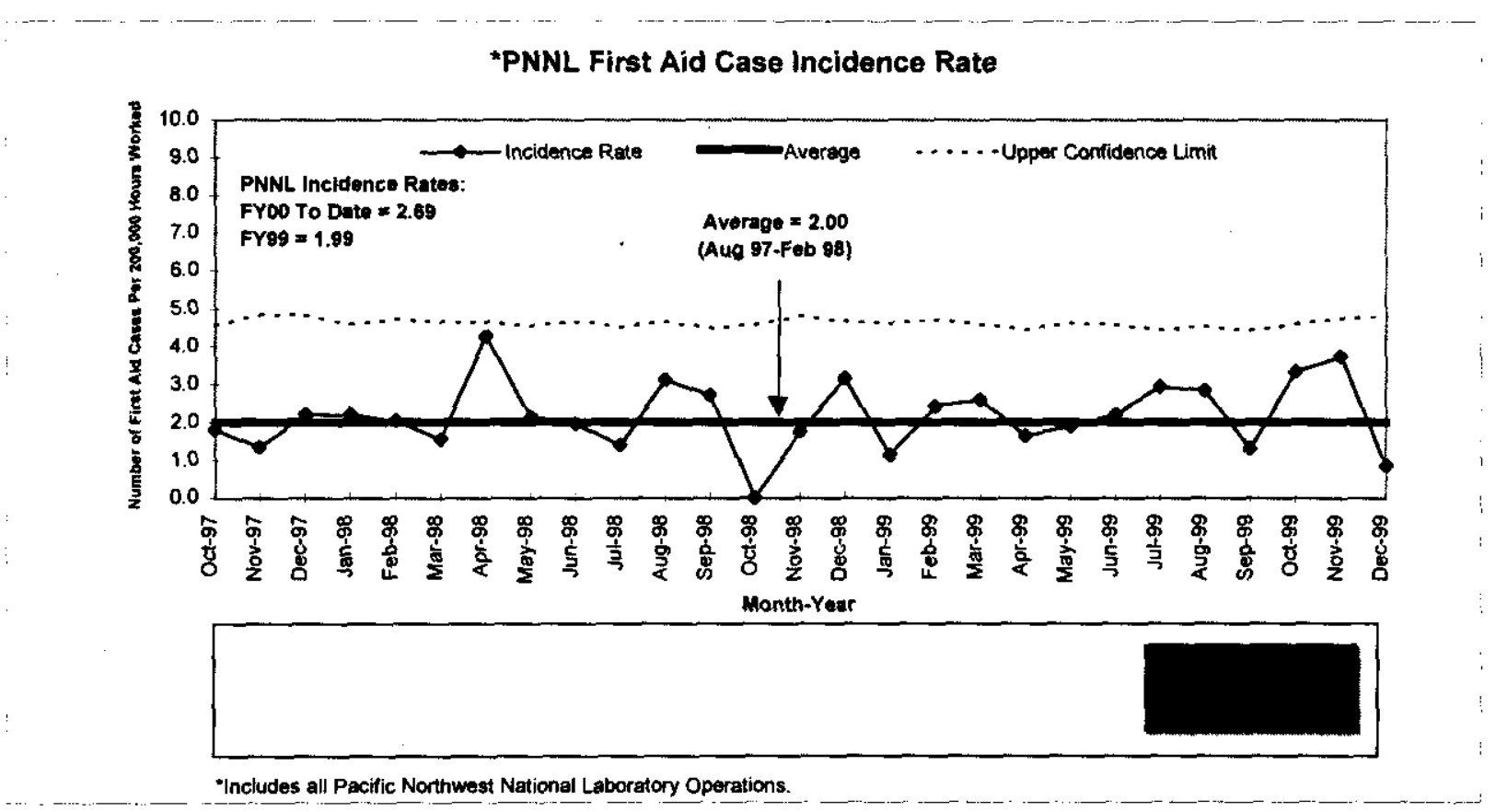




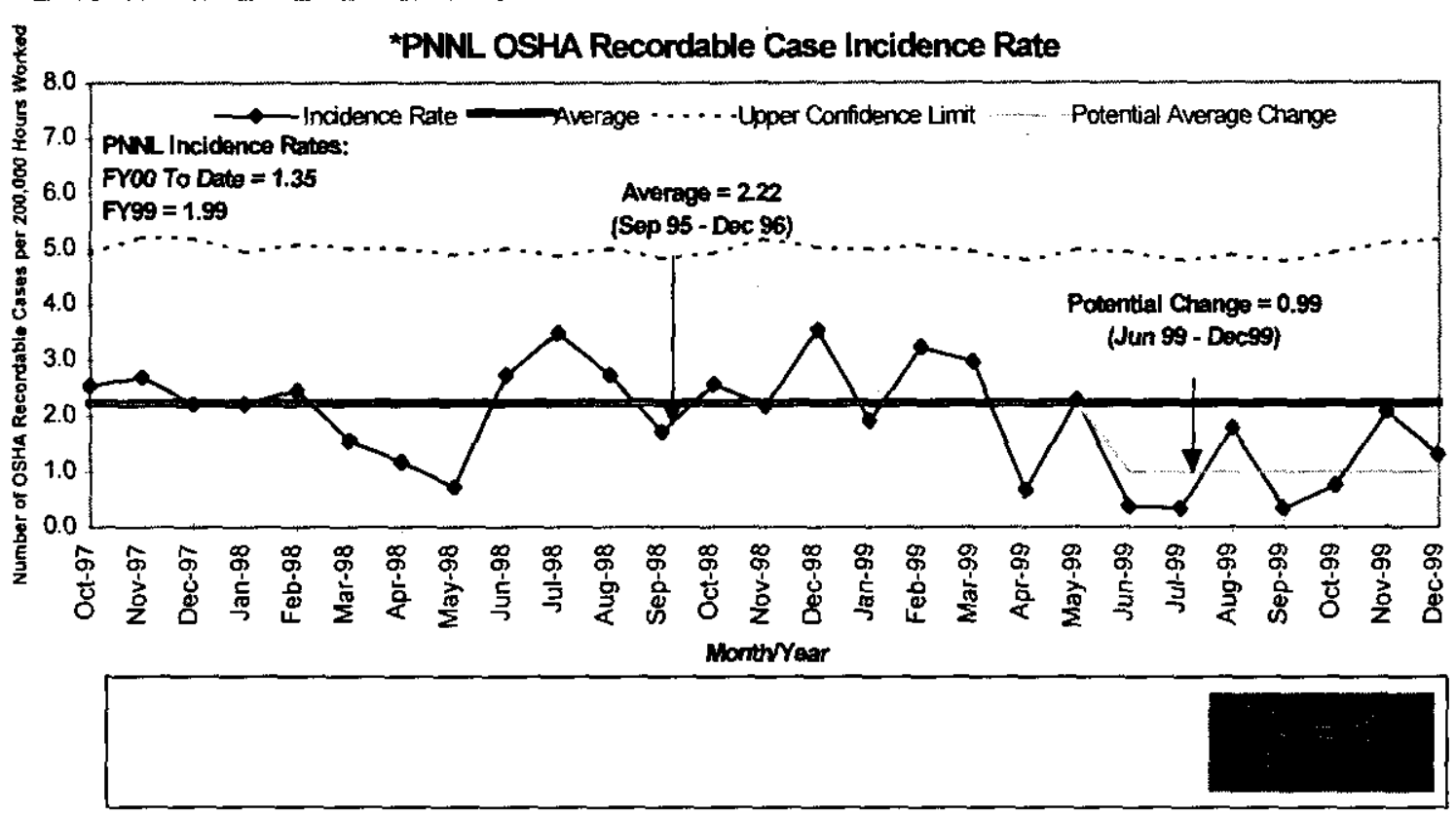

*Indudes all Pacific Northmest National Laboratory Operations.

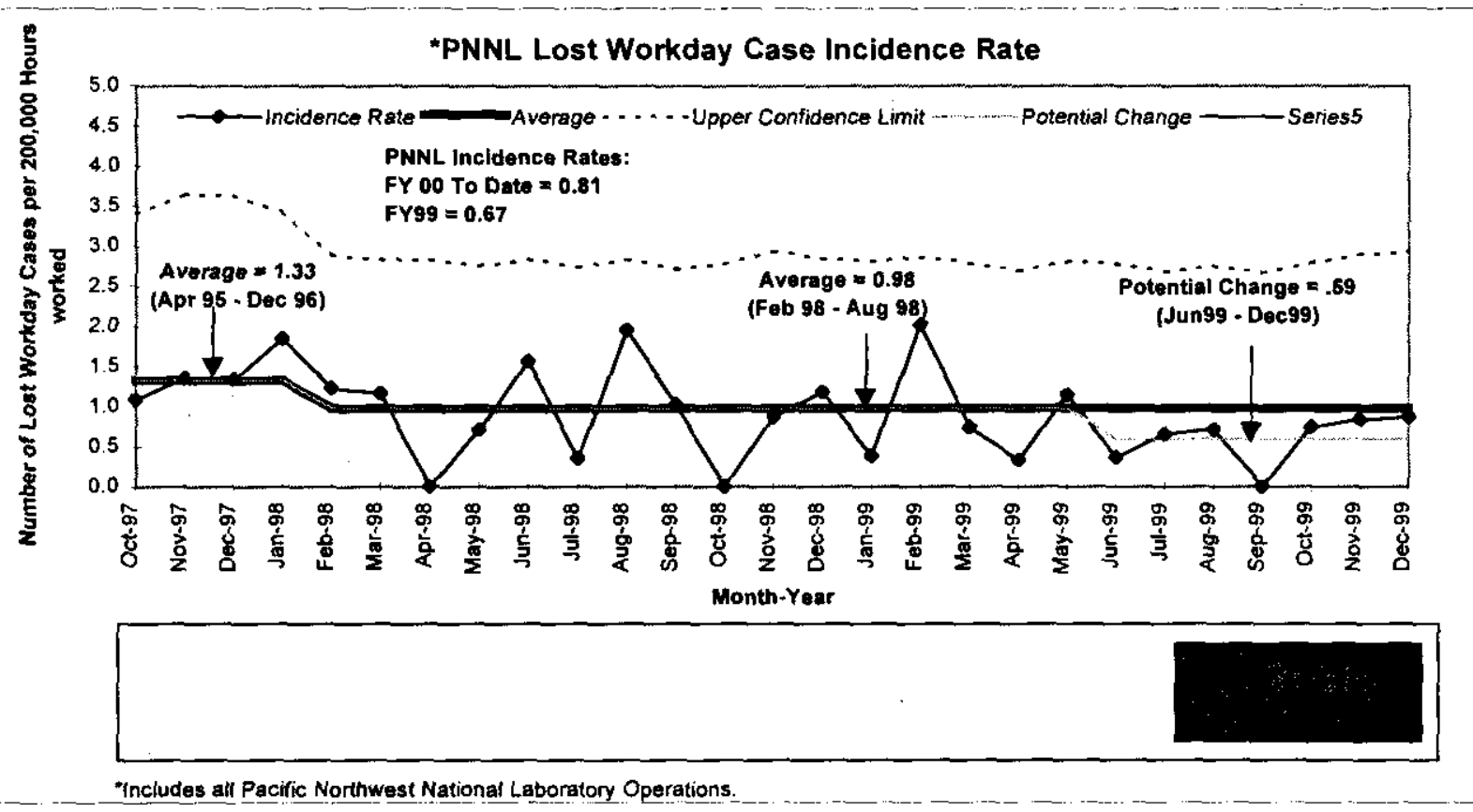




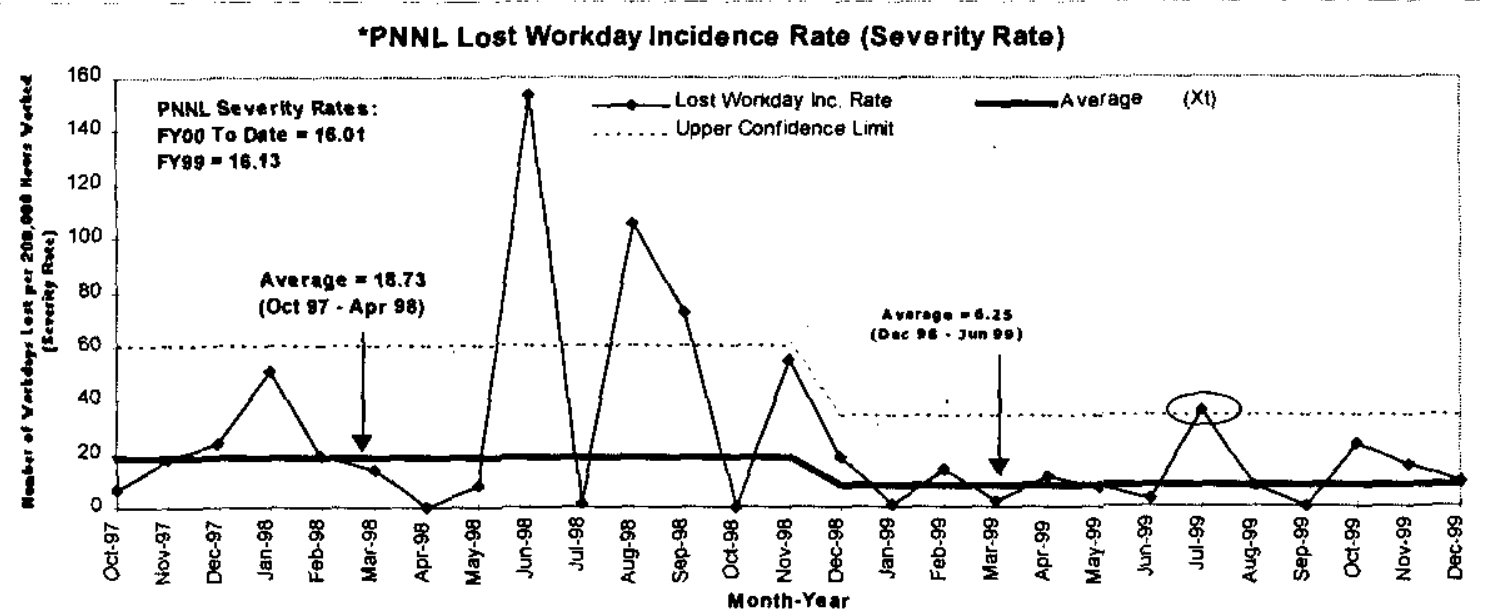

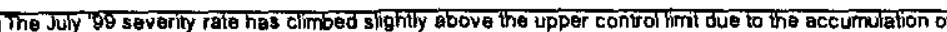
additional lost w ork days on an ongoing case.

"ncludes all Pacific Northw est Nationai Laboratory Operations

\section{Cost/Schedule Performance Stoplight}

The following rating reflects overall performance for activities conducted by PNNL. (Narrative not required when rating is green.)

\section{Green: Satisfactory}

Yellow: Significant improvement required

Red: Unsatisfactory 
$T^{1}$ his section provides cost and schedule performance, any significant issues, and upcoming baseline change requests for the period covered.. In Fiscal Year (FY) 2000, Battelle Memorial Institute has lead responsibility over PBS RL-ST01, PNNL Waste Management WBS 1.7.1.

\section{Mission}

WBS 1.7.1 provides PNNL with waste management services and compliant operations in support of science and technology development for the multi-program needs of the DOE Complex:

- Provides essential surveillance and maintenance of DOE laboratory facilities assigned to PNNL for safe containment of radioactive and hazardous materials

- Provides infrastructure required to manage wastes and effluents currently generated at the Laboratory

- Provides operational compliance services to meet regulatory requirements and operating permits including environment, safety $\&$ health regulations

- Manages legacy wastes and contamination remaining from past PNNL research operations.

\section{Performance Data and Analysis}

The cumulative cost variance of positive $\$ 0.0 \mathrm{M}$ is not significant and it is expected that the baseline activities will be completed within funding allocation. The cumulative schedule variance of negative $\$ 0.4 \mathrm{M}$ is primarily due to 1 ) delayed start in fabrication of drum handling system for high dose waste. Staff members determined that the inner shipping container would not meet the 4-foot drop scenario imposed by the safety analysis report for packaging (SARP). The inner container is being redesigned to ensure it will meet code requirements for a 4-foot "normal" drop; 2) fewer solid waste disposal shipments than estimated for this time of year; and 3) delays in completion of modifications to the Radioactive Liquid Waste System (RLWS). The RLWS delay has impacted cask shipments to the 200 Area for final disposition. The estimated usage date of the RLW tank is March 2000, which leaves only six months of the fiscal year to achieve a milestone that was planned to be accomplished in one full year. At this time, as much waste as possible is being held for the RLW tank when it comes on line.

A change request is in process to modify the RLWS baseline to reflect impacts of additional post start activities. Fluor Federal Services is presently reviewing these work process requirements to ensure that the estimate to complete and the remaining activities can be completed safely. The final RLWS tie-ins will begin the last week of January and be completed at the end of February. The project team will continue to monitor the remaining activities to closure. 


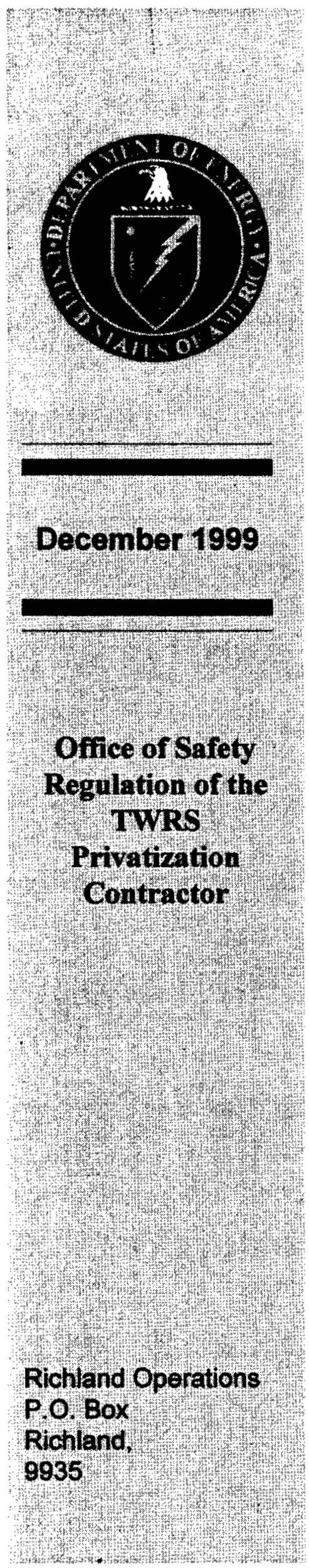

\section{Regulatory Unit}

Monthly Performance Report

Ofince of Safety

Regulation of the TWRS

Privatization

Contractor

Richland Operations

P.O. Box

Richiand

9935 


\section{Table of Contents}

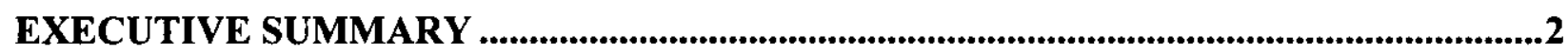

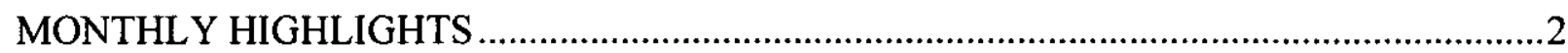

Inspection Program Activities..................................................................................... 2

Inspection of BNFL's Safety Integration for Design Activities ................................................. 2

Inspection of BNFL's Authorization Basis Management Process................................................. 3

Inspection Procedure Development...................................................................................... 3

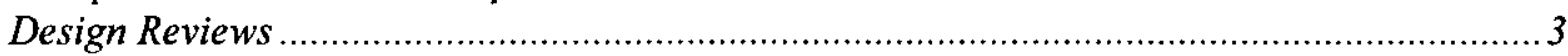

Integrated Safety Management Reviews (ISM Cycle II) ............................................ 4

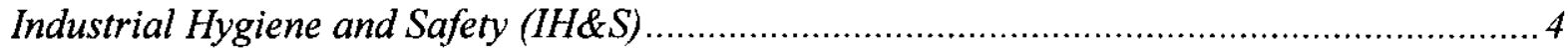

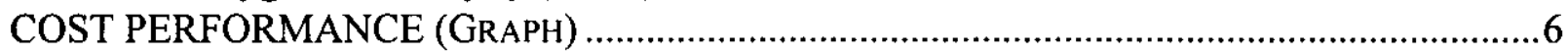

COST PERFORMANCE SUMMARY …....................................................................... 7

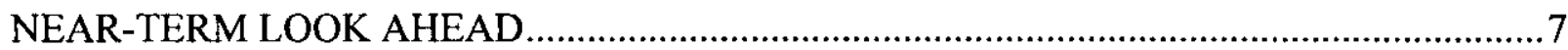

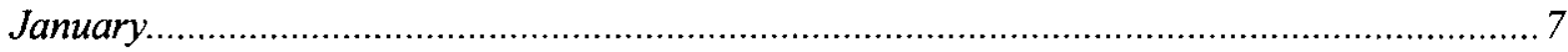

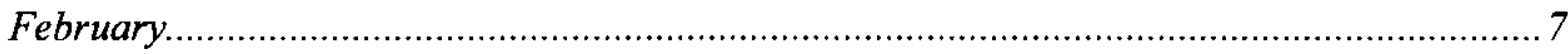

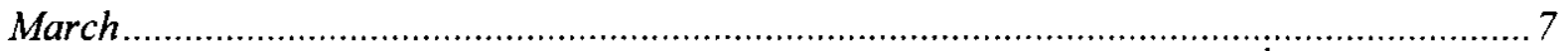

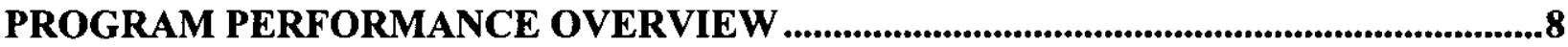

PERFORMANCE SUMMARY (CHART) - PROGRAM DIRECTION AND PROGRAM SUPPORT......9

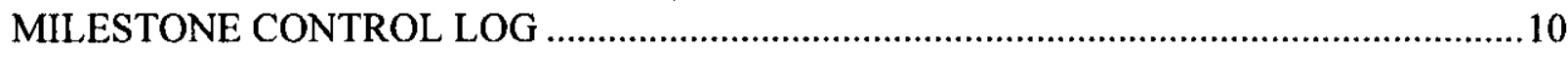

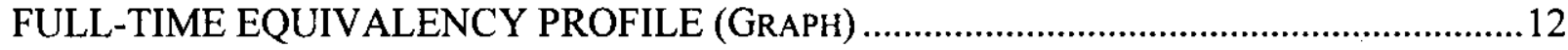

CHANGE CONTROL STATUS LOG ......................................................................... 13 


\section{EXECUTIVE OVERVIEW}




\section{EXECUTIVE SUMMARY}

Through design reviews, safety reviews and inspection the Regulatory Unit has identified and is working with BNFL to resolve three significant issues that must be resolved prior to proceeding with Part B-2: dose assessment methodology, authorization basis (AB) maintenance, and adherence to procedures.

The issue of dose assessment methodology was first identified during review of BNFL's Initial Safety Assessment. BNFL and the RU participated in a Topical Meeting to further discuss the issue. BNFL submitted their proposed methodology in October 1999, for RU review, but it was found to be missing necessary detail that would not become known until the Construction Authorization Request (CAR) was submitted. In order to preserve the prospects for timely review of the CAR, it is necessary that these uncertainties be resolved. There exists a potential that this issue will be resolved in late January or February.

The RU identified inadequate BNFL management of the TWRS-P WTP authorization basis as an issue during inspections in October and November. The inspections found that the Contractor had failed to establish a process that would ensure the authorization basis is maintained current, as required by the contract, with the facility design. The RU and BNFL will meet to discuss this issue again on January 27,2000 . BNFL contends that maintaining the $\mathrm{AB}$ is cost prohibitive. The RU considers much of the cost is due to BNFL self-imposed administrative burden. Resolution of this issue is not expected until March or April.

Nearly all of the eleven design phase RU inspections of BNFL have identified procedure compliance problems. To address this RU concern, BNFL has established a team to determine the root cause of this problem. The team has been tasked to complete its evaluation by January 31,2000 . The RU will assess the effectiveness of the BNFL corrective actions through follow-up inspection.

\section{MONTHLY HIGHLIGHTS}

During the reporting period, the Regulatory Unit (RU) completed or continued efforts on the following key work activities:

- Issued Authorization Basis Management and Safety Integration Inspection reports

- Observed design and integrated safety management reviews

- Issued detailed planning for Industrial Health and Safety Regulatory planning

The following details the above information.

\section{Inspection Program Activities}

\section{Inspection of BNFL's Safety Integration for Design Activities}

The Regulatory Unit issued an inspection report on the Safety Integration of the BNFL design. The inspection team determined that BNFL was implementing an effective management and design program to ensure safety integration throughout the project. BNFL management, staff, and design 
programs reflected a good safety culture that was evident in all areas reviewed. The inspection team identified one Finding based on four minor examples of failure to follow procedures. These included:

- Failure to specify review criteria prior to reviewing documents in accordance with procedures

- Failure to follow administrative aspects of the Project Safety Committee procedure

- Failure to maintain document review and comment forms in accordance with procedures

- Failure to control the output of the Hazard Analysis teams in accordance with procedures

\section{Inspection of BNFL's Authorization Basis Management Process}

The Regulatory Unit issued an inspection report associated with follow-up issues identified during an inspection conducted from October 4 - 8, 1999, on BNFL's Authorization Basis Management process. The inspection team concluded that BNFL's Authorization Basis Maintenance process was disjointed, confusing and in some cases inconsistent with TWRS-P Contract requirements. Four Findings and two observations were identified.

Findings:

- Failure to establish a process that ensured design-related aspects of the authorization basis were maintained current with the facility design

- Allowing untrained personnel to perform screening reviews and safety evaluations

- Two examples of staff not following procedures

- Revising information in a quality-related record without revising the record as required

Observations:

- Authorization Basis Maintenance procedures contain inconsistent direction from procedure to procedure.

- The process for notifying the RU of changes to an authorization basis document when the effectiveness of the document did not change as a result of the revision was informal instead of formal.

\section{Inspection Procedure Development}

The RU continues development of limited construction and construction inspection procedures. Thus far, approximately 40 inspection procedures have been identified for the construction phase (excluding pre-operational testing). These procedures include process activities such as geotechnical, structural concrete, structural steel, electrical, etc., Quality Assurance/Quality Control activities, and radiological control activities. To date, seven draft procedures have been approved, six others are being reviewed, and a number of procedures are in various states of development. The RU plans to have all these inspection procedures completed by August 2000, at least three months before their intended use.

\section{Design Reviews}

The effectiveness of design reviews has significantly increased from the initial reviews conducted in second and third quarters of CY 1999. Currently, design reviews are facilitating integration among disciplines and between primary processing facilities. Participants routinely include safety and operations representatives who are providing meaningful input.

However, BNFL has completed less than 60 percent of planned design reviews, which indicates BNFL is behind schedule. Although behind the Integrated Master Plan schedule, BNFL has made significant 
design progress in the past two months. The design has become more detailed, integration has improved, operating issues have been raised and addressed, and features to control hazards are being included. Significant design changes in areas such as pretreatment to remove sulfate, LAW melter shielding concepts, and the deletion of HLW melter breakdown cell impact many interfacing systems contributing to slower than anticipated progress in the advancement of the design. Significant progress is needed to bring the design to a level of maturity to support the planned submission of Construction Authorization Request in late November.

In December, RU staff members observed the following five single discipline design reviews:

- High-Level Waste (HLW) and Low-Activity Waste (LAW) Product Handling, Lidding, Sampling, and Weld

- HLW Phase 2 Layout

- HLW and LAW Product Decontamination, Swab, Monitor, and Export

- Pretreatment Evaporators and Ultra-filtration

- HLW and LAW Container Fill

\section{Integrated Safety Management Reviews (ISM Cycle II)}

BNFL is currently performing its second iteration (ISM Cycle II) of analysis of the hazards and hazardous situations associated with the design of the TWRS-P WTP. The first iteration (Cycle I) identified the hazards and hazardous situations, and in most instances established strategies for controlling the hazard. In ISM Cycle II, BNFL is identifying the standards with which to design, construct, and operate the facility.

Regulatory Unit oversight of Integrated Safety Management Reviews (ISM Cycle II) has determined that, in general, BNFL has assembled appropriate hazards analysis teams with representation from design, safety, and operations. The BNFL team members actively participate in the hazard analysis process and conduct a thorough analysis of the hazards and hazardous situations.

The RU observed 8 ISM Cycle 2 hazards identification meetings, as follows:

- Pretreatment System 540 (Process Vessel Vent)

- HLW System 100 (Receipt and Blending)

- Pretreatment System 210 (HLW Receipt Tanks)

- LAW System 600 (Reagents)

- BOF System 600 (Reagents)

- Pretreatment Systems 310/320 (Cesium Removal by Ion Exchange and Nitric Acid Recovery)

- Pretreatment Systems 120/130 (LAW Feed and Melter Feed Evaporation)

- Pretreatment System 110 (LAW Receipt).

\section{Industrial Hygiene and Safety (IH\&S)}

The TWRS-P contract requires a complete IH\&S regulatory program to be in place before start of construction (including limited construction) of the TWRS-P Waste Treatment Plant (WTP), which is currently planned for December 2000. Based on direction from EM-1, the RU is developing a program to regulate Occupational Safety and Health at the BNFL facilities. The RU plans completion of the 
IH\&S regulatory program well in advance of December 2000. To meet this goal the RU recently completed a cost estimate and schedule, and prepared four documents. The first two were issued for contractor review and the last two were circulated for internal review including DOE-HQ. The four documents are:

1. A document providing the RU position on, and expectations for, BNFL's IH\&S program.

2. Review guidance for the IH\&S program for construction start.

3. A document providing the RU position on conducting design reviews for IH\&S.

4. An IH\&S Regulatory Plan.

Because BNFL prefers OSHA to the RU as the IH\&S regulator, in late December BNFL sent a letter to the Department of Labor (DOL) requesting reconsideration of OSHA's initial decision not to regulate Industrial Hygiene and Safety (IH\&S) at the BNFL WTP. The letter provided a specific "proposal" for OSHA regulation - primarily a background statement and a list of factors favoring OSHA regulation. The letter notes the proposal was reviewed by the AFL-CIO and local Building Trades and implies their support.

The DOL agreed to meet with BNFL on the proposal and asked that DOE also attend. The RU and EH-51 (Office of Occupational Safety and Health Policy) will attend this meeting planned for January 25,2000 , in Washington, D.C. The RU supports OSHA regulation. However, significant technical (e.g., OSHA radiological standards for workers) and funding issues are unresolved. EH-51 believes OSHA will not accept the regulatory responsibility for the BNFL facilities. 
㞻 $\underset{\infty}{\stackrel{R}{m}}$

$\frac{0}{2} \stackrel{n}{\stackrel{2}{N}}$

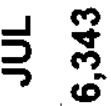

E

Z

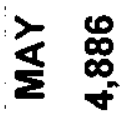

$\frac{\alpha}{2} \frac{8}{8}$

$\underset{\substack{c \\ \text { in }}}{\frac{\infty}{n}}$

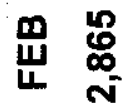

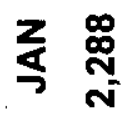

$\begin{array}{ll}\frac{2}{a} & 0 \\ \frac{\sigma}{\sigma} & \frac{2}{5} \\ \frac{1}{2} & 0 \\ \sum_{0}^{4} & 0\end{array}$

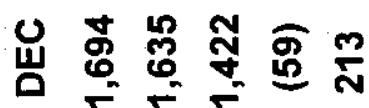

율

ঢ

$$
\begin{aligned}
& \text { Я }
\end{aligned}
$$

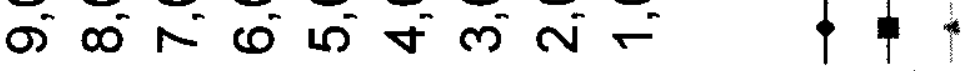




\section{COST PERFORMANCE SUMMARY}

The fiscal year to date cost through December indicates a financial underrun of $\$ 272 \mathrm{~K}$. This underrun is attributed to a favorable cost variance of $\$ 213 \mathrm{~K}$ and an unfavorable schedule variance of $\$ 59 \mathrm{~K}$. The cost variance is due primarily to savings associated with Design Reviews, Authorization Basis Maintenance, Internal Policy development, Construction Authorization Review Preparation activities, Position Paper development, and Review Guidance development. The schedule variance is due to delays in receiving comments from BNFL on review guidance for the Standards Approval Package (SAP), the Limited Construction Authorization (LCA), and CAR. In addition, BNFL has experienced delays in fixing site and facility layouts, which has led to slower than planned progress in the design process leading to delays in scheduled Design Reviews.

There are no programmatic impacts anticipated at this time and the favorable cost variance will be reprogrammed to initiate new emergent priority workscope within the RU.

\section{NEAR-TERM LOOK AHEAD}

\section{January}

- Issue Evaluation Report on BNFL's QAPIP, Rev. 4C 1-07-00

- Conduct Design Process Inspection 1-10-00

- Issue Tri-Annual Openness Report 1-21-00

- Conduct Topical Meeting on Risk Objectives, Sellafield database 1-25-00

- Issue Revised Interface Plan

$1-31-00$

- Observe Design and Safety Reviews

\section{February}

- Issue Revised CAR, LCA and SAP Guidance 2-01-00

- Conduct Employee Concerns Inspection 2-07-00

- Participate in RU/BNFL interface workshop 2-09-00

- Issue Design Process Inspection Report 2-14-00

- Present Thirteenth Quarterly RU Report 2-17-00

- Conduct Topical Meeting on Electrical System 2-22-00

\section{March}

- Conduct Training \& Qualification Inspection 3-06-00

- Issue Employee Concerns Program Inspection Report 3-13-00

- Conduct Topical Meeting on LAW/HLW Melter Design \& Safety Issues 3-21-00 


\section{PROGRAM \\ PERFORMANCE OVERVIEW}



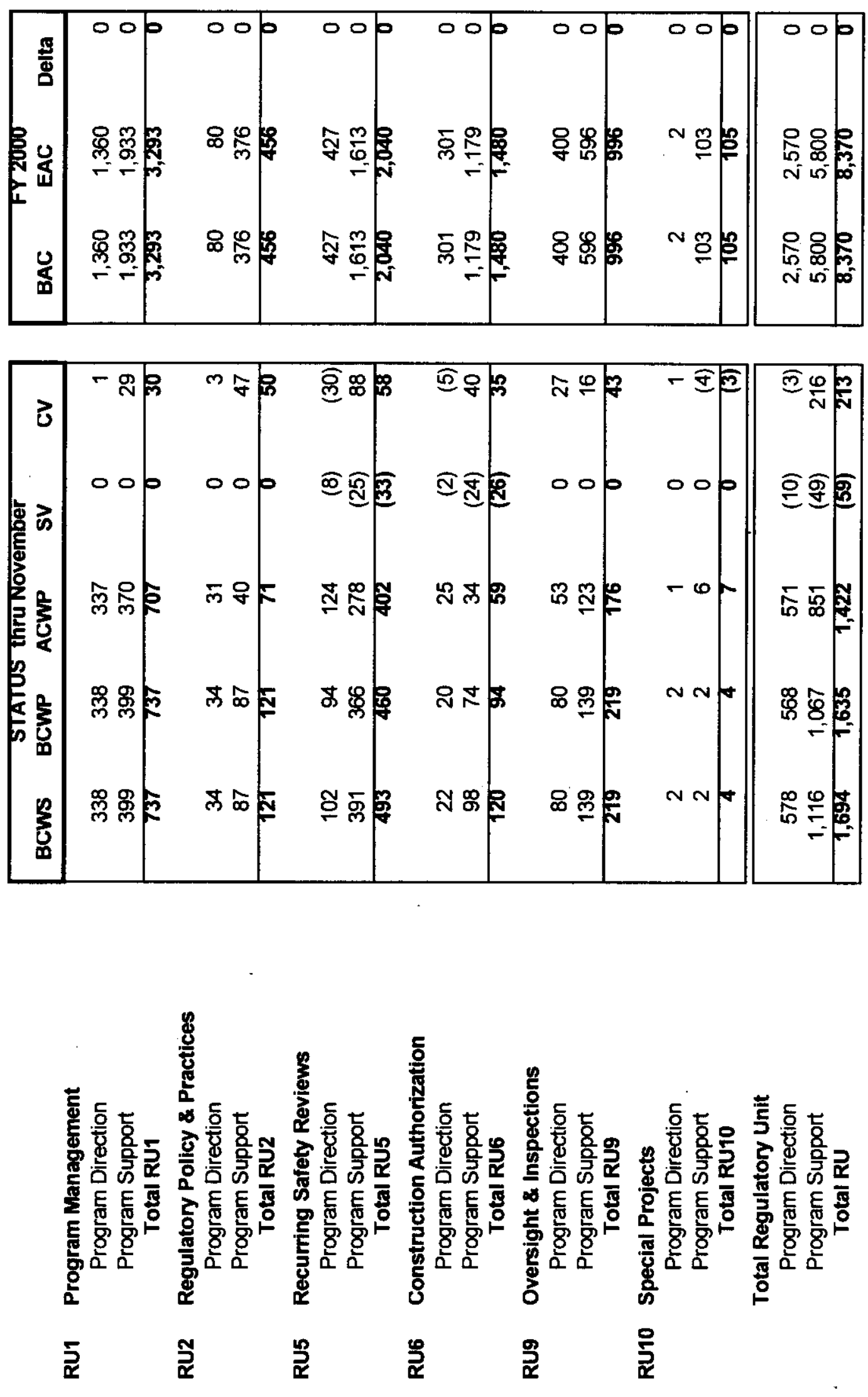


\section{5 \\ उ뇐 \\ 为这要 \\ 论}

幽资

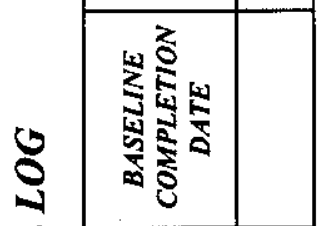

2.888 .888 .8888 .88

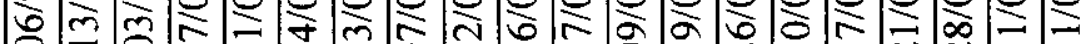

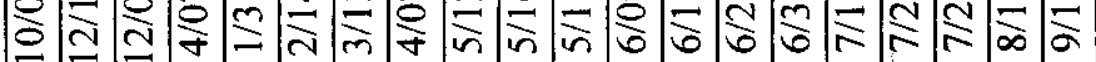

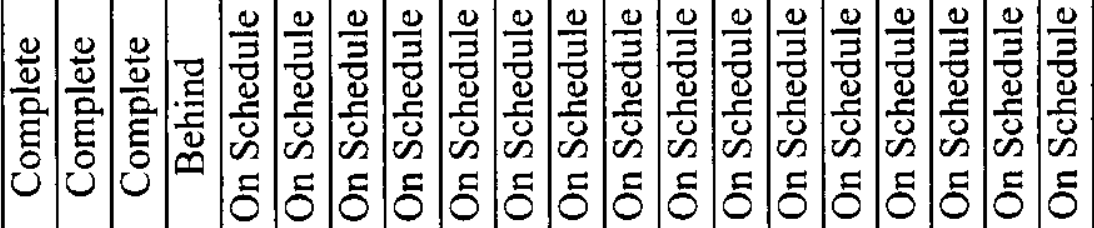

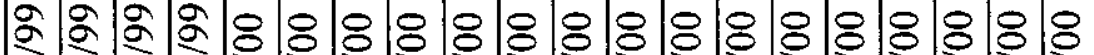
4.

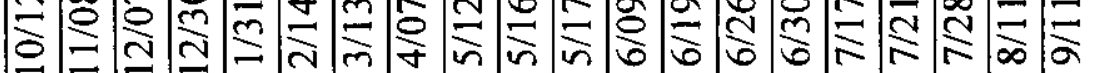

:

‥

要

.응

苋.

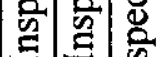

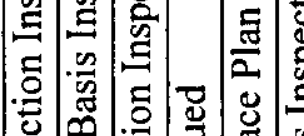

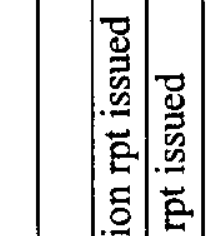

马्ّ

苋

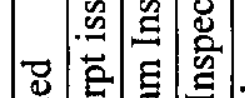

章

离

की

营

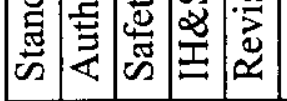

o

क्ञ

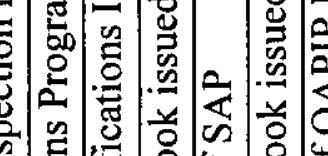

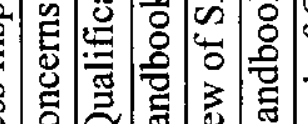

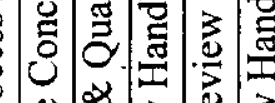

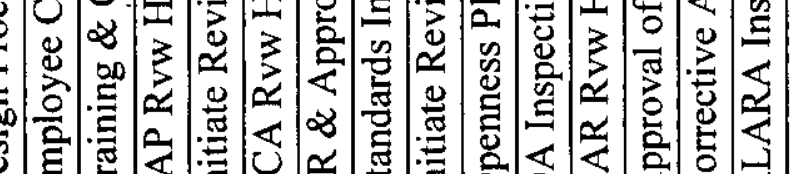

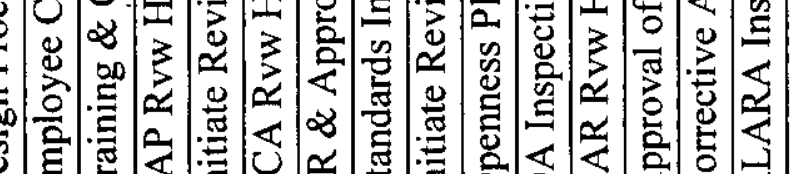

总

葛

总

它总芯

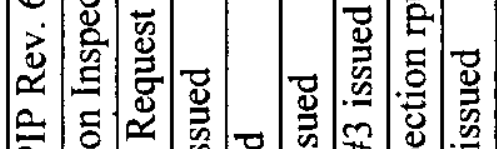

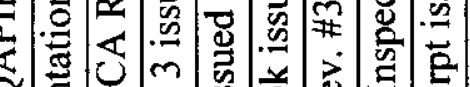

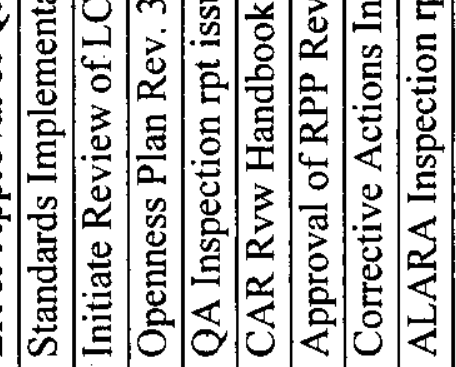

สิธิธีชิ์

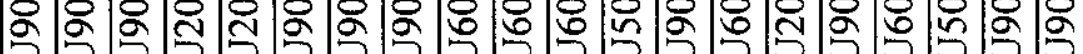

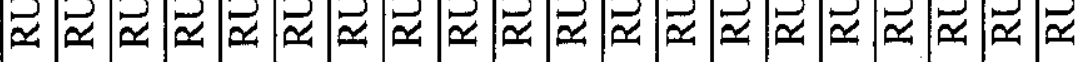

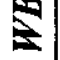

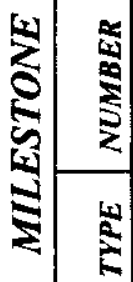

응

官菅全

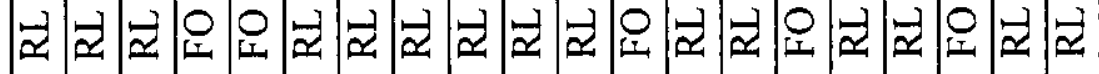




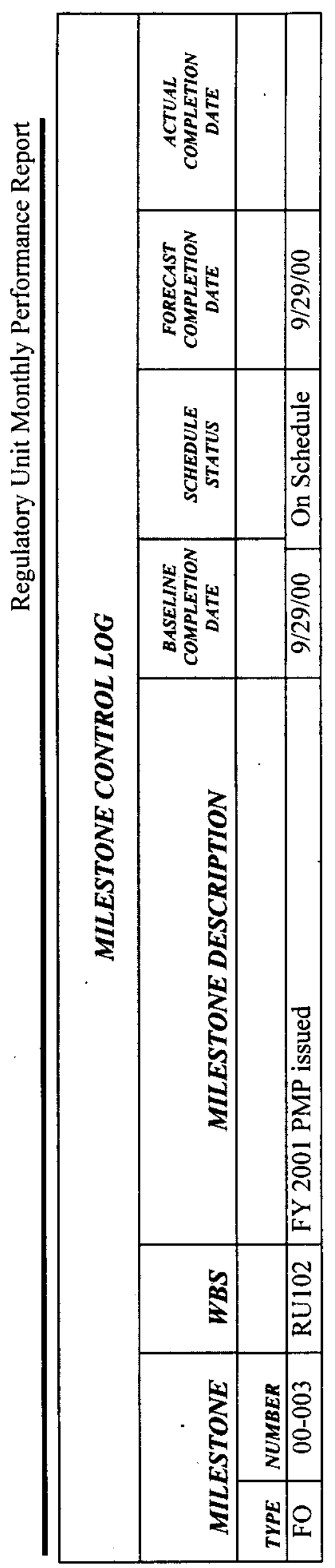



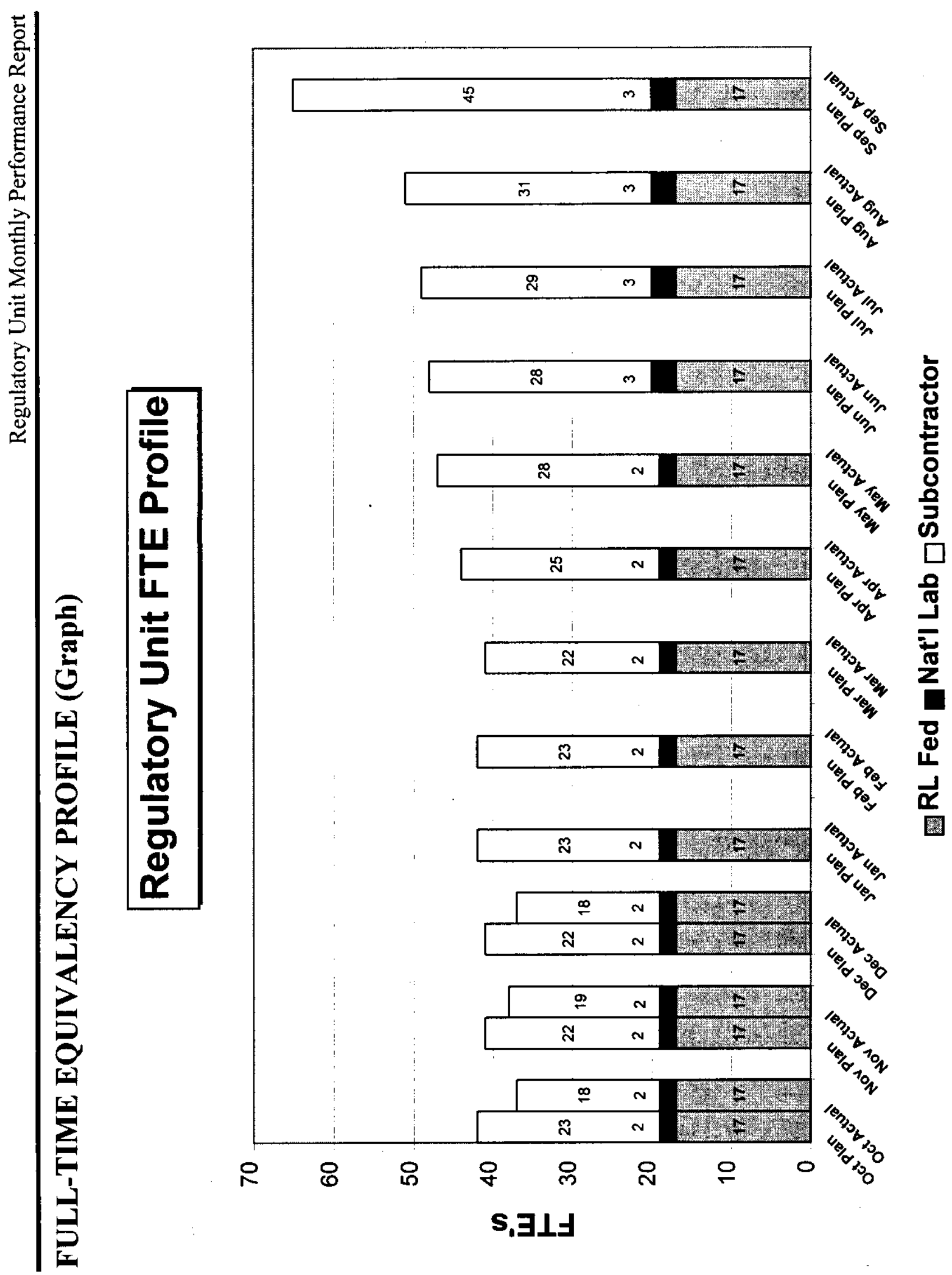

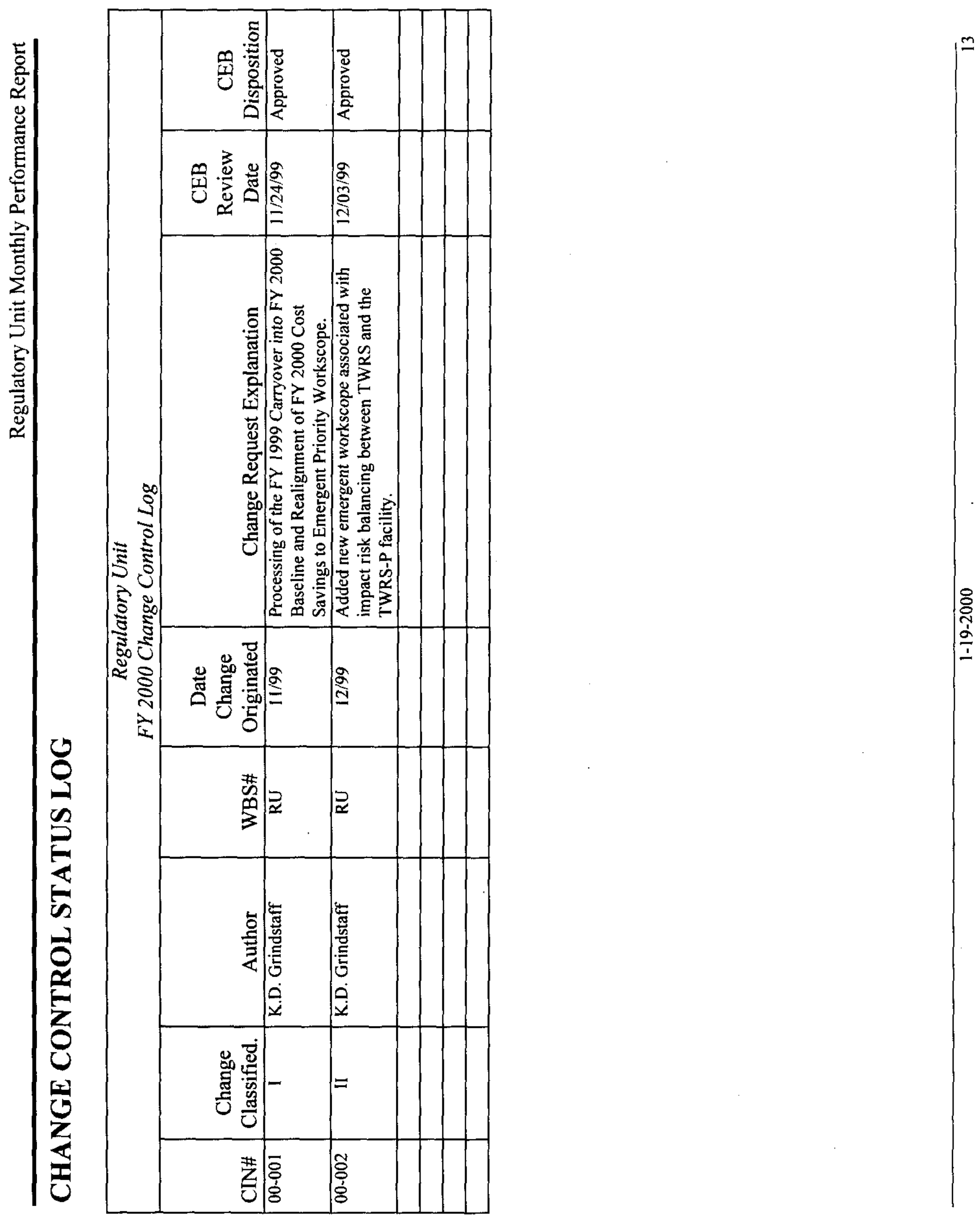